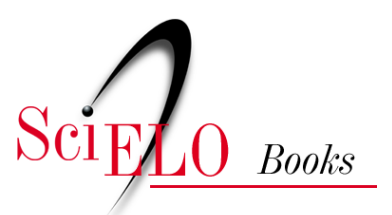

\title{
2. O surgimento dos estudos sobre alimentação e nutrição (1934-1939)
}

\author{
Eronides da Silva Lima
}

\section{SciELO Books / SciELO Livros / SciELO Libros}

LIMA, E.S. O surgimento dos estudos sobre alimentação e nutrição (1934-1939). In: Mal de Fome e não de raça: gênese, constituição e ação política da educação alimentar. Brasil, 1934-1946 [online]. Rio de Janeiro: Editora FIOCRUZ, 2000, pp. 45-148. ISBN: 978-85-7541-611-2. Available from: doi: 10.7476/9788575416112.0005. Also available in ePUB from: http://books.scielo.org/id/xxmyz/epub/lima-9788575416112.epub.

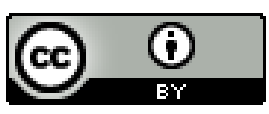

All the contents of this work, except where otherwise noted, is licensed under a Creative Commons Attribution 4.0 International license.

Todo o conteúdo deste trabalho, exceto quando houver ressalva, é publicado sob a licença $\underline{\text { Creative Commons }}$ Atribição 4.0. 


\section{O SURGIMENTO DOS ESTUDOS SOBRE ALIMENTAÇÃO E NUTRIÇÃO (1934-1939)}

A emergência de um conjunto de estudos e pesquisas sobre alimentação e nutrição, nos anos de 1934 a 1946, indica os elementos constituidores da ciência da nutrição e, dentro dela, a educação alimentar. Nesse sentido, o período de 1934 a 1939, em pauta, teve como questão principal a caracterização inicial do objeto $e$ a construção dos modelos explicativos que definissem o estatuto científico desse campo. Nesse aspecto, a evidência de duas tendências no conjunto da produção, do período em foco, quanto à delimitação do problema social objeto do conhecimento, trouxe à tona, numa primeira instância dessa análise, a questão do porquê da produção desse conhecimento. Em ambas as tendências foi marcante a assimilação, por parte dos intelectuais, do pensamento do médico e professor argentino Pedro Escudero, entre outros. ${ }^{5}$

Considerando a primeira tendência, esse estudo se iniciou com o livro $O$ Problema Alimentar Brasileiro, de Josué de Castro (1934), em que ele indicou a Grande Guerra (1914-1918) como marco histórico das mudanças ocorridas nos métodos de investigação e aplicação prática das ciências médicas, configurando uma reformulação geral que, embora não apresentasse nítida distinção em seus fundamentos da medicina do século XIX, refletia acentuada diferença no decorrer do tempo. Algo indicava um momento de renovação que, sob o lastro de uma cultura bem fundamentada, canalizava o espírito de investigação para as deduções seguras da observação e da experimentação técnica. Os estudos da moderna fisiologia e do grupo das ciências correlatas, como a físico-química, a física biológica e a química biológica, reaproximavam a medicina prática da verdadeira ciência, marcando o advento do período fisiológico.

5 Concomitantemente, a obra clássica de Escudero, Alimentação (1934), foi traduzida por Hélion Póvoa \& Waldemar Berardinelli, constituindo-se em referência fundamental à produção intelectual em apreço. 
Assim, Castro (1934) introduziu o estudo do problema alimentar brasileiro nessa perspectiva fisiológica, começando com um prefácio de Escudero, o qual registrou a sua passagem pelo Brasil e reiterou o empenho de Castro em pontuar, em seu ensaio, fatos aparentemente característicos do metabolismo basal, experimentalmente evidenciados em habitantes de Recife (Pernambuco). Em meio às controvérsias externas que pairavam sobre as investigações que se voltavam para a influência do clima sobre a alimentação dos povos, Castro, naquele livro, elegeu o clima como primeira variante no estudo do problema alimentar, e primeiro elemento a compor a noção de meio utilizada no percurso de toda a produção do período em análise.

Coincidentemente, Escudero, em seu livro Alimentação (1934), destacava que, no século passado, esse assunto não seduzia os investigadores, que praticavam estudos isolados e de pouco valor prático, como os de Peligot, Liebtiz e Rubner, sendo necessário chegar a 1906 para ver surgir, na obra de Atwater e Bryant, os primeiros trabalhos de fôlego. Transcorridos os primeiros acontecimentos de 1914, a provisão alimentar dos exércitos constituía um grave problema a ser resolvido, e, nesse sentido, a guerra não só ensinou a destruir, como também ensinou a criar: as ciências puras a ela emprestaram sua colaboração, e a medicina progrediu rapidamente.

Nesse momento renovador, em que a medicina se orientava pela moderna fisiologia, a ciência da nutrição se impôs como verdade, a ponto de nela a Grande Guerra marcar uma etapa e impor novos horizontes à sua evolução. Firmaram-se as instituições e tomaram impulso os estudos: em Paris, com a modificação dos estatutos da Sociedade Scientífica de Hygiene Alimentar; na Itália, com Luciani, que publicou, em 1917, um trabalho sobre alimentação humana; na Inglaterra, com as realizações do Conselho de Pesquisas Médicas do Ministério da Agricultura; na Alemanha, cujos esforços estiveram voltados para a produção, administração e utilização dos alimentos. A moderna Rússia, que, em 1929, não contava com qualquer centro técnico relacionado à questão alimentar, na década de 30 já dispunha do primeiro Instituto de Nutrição, fundado em Odessa. Outros similares foram criados em Rostov, Khakof, Moscou, Kiev, Voroney e Leningrado, e, nos dois primeiros, mais de 200 especialistas, incluindo médicos, engenheiros e economistas, se voltavam para as pesquisas sobre alimentação e nutrição (Escudero, 1934).

Isso põe em evidência o surgimento, no interior das ciências médicas, de uma nova racionalidade essencialmente instrumental, e é por esta ótica que deve ser analisada a gênese e a constituição da educação alimentar. Havia um problema social a ser resolvido, pois o estado das sociedades indicava 
que a maioria da população vivia em subalimentação, ao passo que uma minoria desperdiçava alimentos comprados. A nova era da nutrição estava vinculada a essa causa social que mobilizou os países a encará-la a seu modo, contando, para isso, com a criação dos institutos de pesquisa e ensino, tendo em vista uma distribuição racional de alimentos em que todos pudessem comer. Vale ressaltar que, segundo Escudero (1934), a educação alimentar era o instrumento norteador desse processo, a exemplo dos Estados Unidos, que iniciaram uma verdadeira cruzada educativa institucional firmada na propaganda, ensinando o povo sobre a melhor maneira de gastar o dinheiro na aquisição de alimentos.

Ao relatar o seu empenho na constituição da ciência da nutrição na Argentina, Escudero assinalava que os países sul-americanos se encontravam à margem deste processo, a exemplo do seu país, onde, embora se detivesse como maior fonte de riqueza a produção de alimentos, possuía universidades que ainda estavam distantes do movimento científico mundial. Os legisladores, imbuídos da legislação do trabalho, ignoravam a importância que tinha a alimentação racional do povo na manutenção da raça, naquele momento de crise universal, em que a Argentina era atingida durante a Primeira Grande Guerra por uma crise de alimentação (de produção, de distribuição e consumo). Se houvesse naquele país uma repartição técnica, composta de dietólogos, engenheiros, químicos e economistas, algo teria sido proposto para a erradicação dessa moléstia 'ridícula' - desnutrição, em meio ao desperdício de alimentos. As estatísticas de todos os povos demonstram que a desnutrição é uma das características das classes trabalhadoras, tendo se chegado a este estado, em conseqüência da ignorancia no manejo do capital-alimento aggravado pelas condições econômicas desfavoráveis. Para ser resolvido esse problema complexo, não basta augmentar os salários; é indispensável ensinar e favorecer a alimentação racional e econômica. (Escudero, 1934:parte do prólogo da edição brasileira)

A influência do pensamento de Escudero (1934) na obra de Castro ficou mais visível quando o autor, no livro A Alimentação Brasileira à Luz da Geografia Humana (1937), reiterou com maior nitidez a emergência do fator econômico e social das nações, como explicação plausível para o interesse que os estudos sobre alimentação e nutrição haviam despertado depois da Grande Guerra:

A guerra paradoxalmente trouxe este benefício - chamou a atenção sobre certos problemas que eram então descuidados, o problema alimentar, por exemplo. A luta que ensangüentou a Europa de 1914 a 1918 veio mostrar a importância do capital-alimento, impondo às nações beligerantes um prodigioso esforço científico para que a fome não pusesse em perigo a sua resistência física. (Castro, 1937:18) 
Com isso, Castro (1937) introduziu um distanciamento entre o movimento científico universal e o estado conceitual do saber na sociedade brasileira, cujo atraso em relação aos avanços obtidos por outros países confirmava uma atitude de descaso, pois, salvo em estudos parciais e isolados, nada havia sido feito de maneira sistemática para estudar os problemas atinentes à alimentação $e$ à nutrição.

Nessa mesma trilha de Castro (1937), Coutinho, em seu livro Valor Social da Alimentação (1937), reiterava que a Grande Guerra revelou as conseqüências da má nutrição, impulsionando o surgimento da ciência da nutrição, e enfatizava que, no Brasil, ainda eram pouco notórias as noções modernas de nutrição, já tão bem conhecidas em países como a Rússia, Alemanha, Áustria, França, Bélgica e Dinamarca, que mais sofreram privações durante a guerra e depois dela.

De fato, houve grande aproximação, entre os autores, em torno dessa narração histórica. A esse respeito, Carmo, no livro Política Alimentar Brasileira (1937), assinalava que em época alguma o problema da alimentação racional do povo assumia tamanha importância e tão grande interesse como naqueles anos:

Se de um lado, entretanto, os progressos da ciência estão a indicar os meios seguros para uma solução satisfatória, por outra parte, a grande crise econômica mundial de após guerra, prolongada até a data presente, e mais ou menos agravada em diferentes países, motivando dest'arte o encarecimento dos gêneros de primeira necessidade parece não permitir uma solução imediata para o problema. Tirar o máximo de proveito nutritivo, com um mínimo de alimento, é de qualquer forma a aproximação de uma solução que só a ciência assegurará. (Carmo, 1937:63)

Assim, Carmo também ressaltava alguns aspectos, como a falta de estudos bem orientados aqui no País, o desenvolvimento de pesquisas praticadas por iniciativa particular sem divulgação e a ausência de unidade nas observações quase sempre unilaterais. Além disso, segundo ele, os homens que estavam em contato com as realidades nacionais ignoravam o respeitável acervo de material acumulado.

Costa, no livro Bases da alimentação racional (1938), também assinalava os feitos científicos do século passado, centrando na Grande Guerra o traço distintivo da nova era da nutrição. Uma vez estabelecidos os princípios da bioenergética, o conhecimento do valor biológico dos alimentos e sua utilização no organismo ganharam impulso com a descoberta das vitaminas. Com isso, estava criada a ciência da nutrição, assegurando, portanto, o estudo científico, certo, rigoroso, dos fatos que tinham relação com a vida, com a nutrição, com 
a alimentação. Todavia, o autor foi mais longe: indicou uma defasagem temporal entre a produção da cultura científica externa e o consumo interno, para realçar o atraso do Brasil nesse processo, deixando implícita nas entrelinhas uma espécie de miopia nacional caracterizada pela incapacidade de pensar a sua realidade, como aqui se vê:

Nunca nos detivemos ante o estudo da nutrição em suas bases científicas, trabalho a que se lançavam, desde o começo deste século, alguns outros países. É verdade que a ciência alimentar só se configurou modernamente, tem apenas quarenta anos. Custou chegar até nós. Agora, que chegou, cumpre-nos difundi-la, leva-la a todos as inteligências e todos os corações, num trabalho de amparo afetuoso ao Brasil, cujo homem vê apontado diante de si um longo caminho a vencer sem que haja em seu corpo o calor que assegura a vitória. (Costa, 1938:prefácio)

Em torno da visível aproximação entre os autores, nesse enfoque histórico, abre-se o precedente para a questão da transplantação das idéias e da relação entre cultura universal e cultura local, tão em voga nos estudos sobre a cultura brasileira. Nessa perspectiva, um aspecto deve ser assinalado de imediato: os intelectuais, ao elegerem a fome/subalimentação como problema social significativo no Brasil, buscando na história externa do surgimento dos estudos científicos a sua justificação, parecem não ter esgotado as causas sociais internas na delimitação desse problema.

Nessa versão justificadora, o atraso científico brasileiro parecia só existir por referência à cultura abrangente, pois os intelectuais, como será visto, prescindiram de uma abordagem sobre o impacto da Grande Guerra no Brasil, considerando que a ciência da nutrição estava-se constituindo, aqui, atrasadamente. Elegendo, assim, a fome/subalimentação como problema social significativo e objeto precípuo dos estudos científicos sobre a alimentação e a nutrição no Brasil, no período de 1934 a 1939, os intelectuais, como que zerando o passado recente, desconsideraram o quadro social e sanitário interno gerado pela Grande Guerra, embora estivessem afinados com interlocutores do movimento médico-sanitário que eclodiu no contexto da efervescência política e cultural durante esse episódio.

Como expressão de uma nova relação capitalista no mundo, o ano de 1914 foi um marco. No Brasil, agravaram-se as dificuldades financeiras decorrentes da conflagração mundial: queda das exportações de café, queda da importação de manufaturados e capitais, inflação dos gêneros alimentícios nos centros urbanos. 
O quadro sanitário, nessa mesma época, indicava que as condições de vida das camadas pobres urbanas havia atingido níveis baixíssimos. Nesse aspecto, se a medicina havia fornecido as armas do triunfo, durante a Grande Guerra, poupando os exércitos da degeneração físico-nutricional, como assinalou Escudero (1934), foi, em compensação, desarmada por uma pandemia de gripe que ceifou 15 milhões de vidas. A chamada Gripe Espanhola, que atingiu o Rio de Janeiro, São Paulo e outras cidades, em 1918, deixou um saldo trágico de óbitos, agravados pela fome, abalando o sonho difundido pelo pausterianismo de que as doenças infecciosas estavam com seus dias contados, e trazendo à tona a precariedade dos serviços sanitários e hospitalares. Tal fato acentuou a insatisfação contra as oligarquias que até então não tinham dado a devida atenção à saúde pública (Benchimol \& Teixeira, 1993).

A crise urbana refletia também a miséria do trabalho no campo. As precárias condições sanitárias nas atividades agrícolas, na moradia e na vida do trabalhador rural criaram os opilados, os maláricos, os tracomatosos representados na figura do Jeca-Tatu criada por Monteiro Lobato, em 1914, como acentua Ribeiro (1993:189):

O Jeca preguiçoso, sem iniciativa para o trabalho produtivo (a não ser a iniciativa nada produtiva de pôr fogo na mata), cansado, sem disciplina para o trabalho organizado, de cócoras, incapaz de se pôr de pé, e em companhia de um cão pulguento, não era o herói nacional do romance regional, era, isso sim, a causa do atraso nacional.

A ciência viria desfazer o mito referido por Lobato. Os resultados do levantamento sobre a situação rural de saúde, realizado por Neiva \& Pena (1917) em viagem pelo sertão da Bahia, Pernambuco, Piauí e Goiás, dava início a um movimento de oposição à tese da indolência lendária do brasileiro, provando que o homem do interior era, sim, uma vítima de todas as doenças imagináveis, inclusive a subnutrição. Em 1917, esses autores publicaram a obra Saneamento do Brasil, em que descreviam de forma elucidativa o quadro de miséria rural, que serviu de inspiração para a criação da Liga Pró-Saneamento. Com isso, Lobato pediu desculpas ao Jeca, aderindo à voz mais alta da biologia, pois reconhecia na obra de Neiva e Pena a consagração da higiene pela qual o Jeca seria modificado, disciplinado e orientado para transformar sua roça em trabalho duro, ser feliz e saudável, ser patrão (Thomas, 1976).

A saúde e a fome/subalimentação eram problemas que estavam, assim, postos na ordem do dia, no mundo, e aqui no Brasil, onde os últimos avanços científicos ainda não haviam chegado, embora já se desenvolvessem os estudos parciais e isolados. Como bem assinala Ortiz (1986), pode-se situar o ano de 
1914 como o momento em que emergia um espírito nacionalista que procurava desvencilhar-se das teorias raciais e ambientais características da República Velha, evidenciando uma unicidade em torno de certo pensamento que prevalecia junto aos intelectuais. Estavam em questão o mundo do trabalho, a educação, a literatura, as artes e as ciências. A Grande Guerra punha em relevo a necessidade de uma nova espécie de mobilização nacional em que os reformadores da saúde pública, da educação, das artes, das ciências em geral se expressavam, insistindo em maiores esforços em cada setor. Assim, vários exemplos de estudos parciais sobre alimentação e nutrição podem ser dados, a partir da eclosão do movimento higienista, que teve no ano de 1917 o seu marco inicial e no ano de 1929 o colapso do tempo que marchava para o fim da República em que cultura e política se entrecortariam num processo de reinterpretação.

Vale registrar que o ano de 1922 assinalava a eclosão do tenentismo, ${ }^{6}$ com a revolta do Forte de Copacabana, o Modernismo, a Semana de Arte Moderna, em São Paulo, e a fundação do Partido Comunista. ${ }^{7}$

Foi em meio a esse clima que o movimento higienista ganhou expressão mediante a realização de vários congressos que já incluíam, em seu corpos temáticos, estudos sobre alimentação e nutrição, os quais esboçavam as primeiras idéias a respeito da educação alimentar. Certamente, o temário dos congressos não estava imune ao campo da disputa institucional pelo controle da saúde pública no País. ${ }^{8}$ O I Congresso Brasileiro de Higiene, realizado em 1923, manteve o tema da urbanização e do saneamento, porém o temário dos Congressos posteriores (1924, 1926 e 1929) foi-se estreitando em relação ao ideário anterior a 1920, concentrando-se muito mais no enfoque dos temas epidemiológicos (doenças transmissíveis), dos métodos de diagnóstico e profilaxia, da análise do modelo institucional da saúde pública vigente e criação de novas estruturas e, particularmente, da educação sanitária. Os higienistas propunham modos de ação que dispensassem os mecanismos coercitivos e punitivos da polícia sanitária vigente desde os primórdios da República e possibilitassem o convencimento da população sobre os modos de controle das doenças em nível individual e coletivo, como enfatizava Fontenelle (1929).

Para os higienistas, o cerne do empirismo alimentar era inerente à própria natureza do problema, que logo se afigurou complexo, e que, com o avanço dos estudos, mais complexo se mostrava. No entanto, os homens de

\footnotetext{
${ }^{6}$ Sobre o movimento tenentista, ver CARONE (1975b).

${ }^{7}$ Sobre a organização das classes sociais, ver CARONE (1975a).

${ }^{8}$ Sobre este assunto, ver BENCHIMOL \& TEIXEIRA (1993).
} 
responsabilidade, fossem ou não cientistas, não tinham proporcionado ainda condições favoráveis aos que pretendiam enveredar nos estudos desse campo. Quanto a isso, preconizavam uma ciência da nutrição (nossa) e reivindicavam do Estado o incentivo às investigações que ultrapassassem os limites individuais.

Os intelectuais, portanto, ao elegerem a fome/subalimentação na conformação do objeto da educação alimentar no primeiro momento da sua constituição (1934 a 1939), zerando esse quadro social e médico-sanitário interno e enfatizando a Grande Guerra como marco histórico em que a ciência adquiria externamente o seu estatuto a partir da fisiologia e da experimentação biológica dos alimentos, no desvendamento das doenças carenciais, ultrapassando a fase químico-analítica, justificavam a escolha do problema social significativo brasileiro - fome/subalimentação - em sua contemporaneidade, como objeto de investigação científica, sem explicar os antecedentes causais desse problema como aspectos determinantes do surgimento do conhecimento que estavam produzindo. Ao contrário, a ciência da nutrição/educação alimentar em constituição precisava se diferenciar do passado. Ao afirmarem que a fome/subalimentação era um fato social sui generis, os intelectuais indicavam que esse fato só poderia ser compreendido nos marcos da biossociologia pela intersecção do método fisiológico com o método geográfico, definindo, assim, a especificidade de uma ciência que pretendiam construir.

O descompasso do Brasil em relação aos países adiantados estava, então, no empirismo dos estudos até então desenvolvidos, sem o caráter sistemático de um método único por meio do qual teoria e 'empiria' se aproximassem. Além de os estudos serem marcados pelo ensaísmo, estavam dispersos no interior de campos afins, como a sociologia, a antropologia, a higiene, a puericultura etc., num momento em que também não existia o espaço específico no interior do qual o saber sobre nutrição adquirisse autonomia. Se havia um elo de coerência e continuidade com a temática passada, ela deveria ser submetida a um processo de reinterpretação. Era nisso que os estudos desse período de constituição da ciência da nutrição/educação alimentar se distinguiam dos estudos antecedentes. Um fato novo era introduzido nesse campo: a fisiologia da nutrição. As investigações fisiológicas, como ponto de partida para o conhecimento científico do problema alimentar brasileiro, representaram forte característica do discurso intelectual. 
Sendo a fome/subalimentação um problema social vivenciado na intersecção do biológico, cumpria examiná-lo sob esse aspecto em consonância com a fisiologia e a geografia e, para tal, era necessário uma formação sobre nutrição. Quanto a isso, os conhecimentos acumulados externamente forneciam as coordenadas para a solução no nível intelectual do dilema interno. Assim, será visto adiante que havia uma continuidade temática que não se constituía simples prolongamento do passado; ela revelava uma ruptura formal que marcava uma descontinuidade histórica na qual se dava a emergência da nutrição como ciência e, no seu âmbito, a educação alimentar. Os intelectuais, uma vez situados no âmbito da Universidade moderna emergente, encontrariam no espaço acadêmico os parâmetros necessários à efetivação da especificidade desse campo e a sua autonomização em relação às demais fronteiras do saber. ${ }^{9}$

Concomitantemente, os intelectuais da segunda tendência assinalada inicialmente nessa exposição, embora estivessem engajados nesse mesmo processo de síntese, rupturas e continuidades, ao prescindirem de uma justificação histórica externa na delimitação do problema social - a fome/ subalimentação - como objeto de investigação científica, se diferenciavam da tendência anterior, parecendo considerar que a época em que viviam era internamente separada das antecedentes e, portanto, independente no que se refere ao surgimento dos estudos científicos desse fenômeno no âmbito universal. Desse modo, o problema em foco era a-histórico, pois não se encontrava nem mais próximo nem mais distante deles, nem noutro lugar, mas num lugar determinado - o Brasil - marcado pela contemporaneidade e não pelo atraso científico.

Nessa visão, era a evidência dos fatos que desafiava a ciência. Botelho (1938:7), no seu livro Os Pequenos Fundamentos da Bôa Alimentação (1938), situava a nossa 'subfome crônica' como um fenômeno que ia passando despercebido aos olhos de quase todos. Apenas os estudiosos, de olhos nas estatísticas, perguntavam em seus gabinetes:

- Que destino terá um povo que não vê melhoradas suas condições raciaes, que vê desnutrida sua população escolar, que registra das mais altas mortalidades infantis do mundo, que vê baixa a média de vida, que assiste ao insucesso relativo da luta anti-tuberculosa e tudo, tudo por causa desta subalimentação que o flagela?

9 Quanto a isso, a criação da Universidade de São Paulo e da Universidade do Brasil veio assegurar as condições materiais e acadêmicas ao desdobramento da produção intelectual. A primeira foi criada pelo Decreto $\mathrm{n}^{\circ} 39$, de 3 de setembro de 1934 , ao passo que a segunda, pela Lei n 452, de 5 de julho de 1937 (ver Brasil, 1938). 
Para o autor, a respeito desse assunto já se falava e se escrevia (eram os sintomas da reação); mas, de prático, ainda não se havia feito quase nada. E ele perguntava o que seria prático na resolução do problema. Nessa perspectiva, o seu livro foi concebido como de natureza elementar que, pela sua estrutura de pequeno volume, estava destinado a servir de guia de nutrição do homem moderno.

Mendonça (1938:8), em seu livro Noções Práticas de Alimentação, aproximava-se de Botelho (1938), quando afirmava que: "Este phenomeno organicamente depressor da nacionalidade é a expressão da precariedade das condições de nutrição, que tem origem próxima na alimentação deficitária ou desorientada". Mas todo esse problema já estava em vias de solução. Tratava-se de apresentar as diretrizes básicas de uma campanha que ele julgava que devia ser feita. Disso se deduz que o Brasil não comportava mais o enfoque do atraso. Conseqüentemente, as noções de alimentação, elaboradas pelo referido autor, destinavam-se a facilitar conhecimentos sobre a boa alimentação, por meio de uma linguagem simples, ao alcance de todos, definindo a concepção do problema e indicando as formas de resolvê-lo.

Fica patente, nessa tendência, que, particularmente nos anos de 1938 e 1939, a justificação da escolha do problema da fome/subalimentação como objeto de investigação se encontrava muito mais na necessidade da configuração instrumental e política do conhecimento científico em processo de elaboração, diante da evidência dos fatos, o que parecia dispensar o enfoque histórico por esses intelectuais. Assim é que Moscoso, no livro Alimentação do Trabalhador (1939), indicava que o inquérito organizado naquele momento pela comissão de salário mínimo, ${ }^{10}$ pela vultosa obtenção de dados, testemunhava mais uma vez a triste realidade da fome/subalimentação (tudo pela falta de um plano político que incluísse a alimentação racional do brasileiro). Quanto a isso, Moscoso (1939) apontava que: "Felizmente agora a solução do importante e grave problema constitui patriótica e decisiva preocupação dos nossos máximos e clarividentes administradores".

10 As comissões de salário mínimo foram instituídas pela Lei nº 185, de 14 de janeiro de 1936, que reza o seguinte em seus artigos: Art. 7﹎ "Para os effeitos desta lei será o Paiz dividido em 22 regiões correspondentes aos vinte Estados, Districto Federal e Território do Acre. Em cada região funcionará uma Comissão de Salario Mínimo com séde na Capital do Estado, no Districto Federal e na do governo geral no Território do Acre". Art. 8 - "As Comissões de Salario têm por incumbência fixar o salario mínimo que prevalecerá na região ou zona de sua jurisdição (...)". Art. 90 - "O salario mínimo será fixado (...) após minucioso inquérito censitário sobre as condições econômicas locaes, afim de proporcionar às Comissões de Salario os elementos de que carecem, para avaliarem a importancia dos recursos mínimos indispensáveis à satisfação das necessidades normaes do trabalhador" (Ver BRASIL, 1938). 
Em suma, o problema da fome/subalimentação, da forma como foi posto, indicava na sua justificação, modos diferentes de conceber o surgimento dos estudos científicos sobre alimentação e nutrição. A definição da tese central em torno desse problema, no entanto, foi o que uniu os intelectuais, no período de 1934 a 1939, embora a sua demonstração tenha levado também a diferentes enfoques metodológicos e a variantes explicativas na constituição da ciência da nutrição e, dentro dela, da educação alimentar.

\section{O valor eugênico e social da alimentação: 'mal de fome e não de raça'}

O conjunto da produção-alvo do mencionado livro revelou que o processo de gênese e constituição da educação alimentar esteve relacionado às demandas externas em que a fome/subalimentação adquiriu significado social e prioridade como objeto de estudo. Tal prioridade na constituição das regras científicas desse campo, no período de 1934 a 1939, mostra que as suas práticas disciplinares ainda não estavam definidas e a sua gênese se encontrava na emergência do método. Outra característica desse período está na importância dada às demandas externas por uma comunidade intelectual cuja identidade ainda não estava clara. Isso significa que, nessa fase da produção científica, as realidades sociais tiveram um grande peso na evolução do conhecimento produzido, o que descarta de partida a possibilidade da sua indeterminação. Assim, ver-se-á que o conhecimento estava circunscrito ao debate econômico, político e cultural do momento histórico em que foi produzido.

Este tópico procura explicitar que o modo pelo qual os intelectuais procuraram responder ao problema foi determinando, pouco a pouco, a base cognitiva da educação alimentar num momento em que imperava uma polissemia sobre a interpretação do social. Dessa maneira, estarão em evidência os elementos de continuidade e de ruptura concentrados em torno de dois aspectos principais:

- a formulação de uma tese central que avançava, no período em foco, ao retirar o preconceito de meio e de raça da discussão genética para a discussão cultural, unificando os intelectuais numa produção articulada, sistemática e unitária;

- a perspectiva de construção de um método único, diante da multiplicidade de métodos que permeavam os estudos parciais e isolados no interior dos diversos campos do saber da época.

Nos marcos desta pesquisa, foi Castro quem primeiro introduziu, no livro O Problema Alimentar Brasileiro (1934), a fisiologia como ponto de partida para o estudo desta questão, ao tempo em que já acenava para a 
perspectiva de articulação da dimensão fisiológica com a dimensão social. Sob o aspecto social, a alimentação se impunha pela necessidade de padronização do mínimo de alimentação das classes deserdadas e a alimentação racional do trabalhador para utilização da sua energia produtiva e pelo estabelecimento de um consumo verdadeiramente científico dos produtos alimentares naturais de origem nacional. Como problema eugênico, não podia ser esquecido que a alimentação era um dos fatores externos mais importantes na constituição dos biotipos vitais. Era pela seleção biotipológica que se elevava o índice vital da raça. Foi em torno dessa perspectiva que Castro (1936:89-90) postulou, no livro Alimentação e Raça, a primeira versão da tese central que unificou os intelectuais nos estudos sobre a alimentação, a saber:

Se a maioria dos mulatos se compõe de sêres estiolados, com 'déficit' mental e incapacidade física, não é por efeito de uma tara racial, é por causa do estômago vazio. Não é mal de raça, é mal de fome. É a alimentação insuficiente que lhe não permite um desenvolvimento completo e um funcionamento normal.

A tese assim formulada deveria ser demonstrada pelo cotejamento dos dados estatísticos e econômicos com os dados de indagação biológica, pois não bastava saber a quantidade de homens que produziam, mas também a sua qualidade. Pelo conhecimento das condições econômicas e dos caracteres biológicos (antropométricos e biométricos) da classe trabalhadora, era possivel chegar a um quadro explicativo das possibilidades econômicas da época e da evolução social brasileira, o que seria, afinal, uma tentativa de interpretação histórica e econômica à luz da biossociologia. Nesse aspecto, Castro se empenhou, na referida obra, no aprimoramento do inquérito alimentar como técnica de investigação da alimentação coletiva, ao passo que indicava os primeiros esboços do método geográfico que permitiria a conexão entre o biológico e o social nesses estudos. Em consonância com Roquette Pinto, Castro (1936) aprimorou esse modelo de inquérito alimentar para uso em áreas rurais, na investigação das condições de trabalho agrícola, relacionadas aos vários meios econômicos em que o trabalho se executava, à maneira como era executado e às condições gerais de vida do elemento humano nos vários núcleos rurais. Embora reconhecesse que a estatística ainda dava os primeiros passos, sem alcançar o delineamento de grandes mapas, era possível proceder ao zoneamento com a finalidade de determinação dos limites de cada grupo territorial. Estabelecendo-se as várias zonas econômicas, geográficas, caracterizadas pela vida econômica do povo, chegava-se à sua classificação $e$ agrupamento sob esses aspectos. 
Foi, no entanto, com a publicação do livro Alimentação Brasileira à Luz da Geografia Humana que Castro (1937:118) expressou detalhadamente os princípios do método geográfico, reapresentando a sua tese com bases mais elaboradas:

a degenerescência do povo é o resultado mais da organização econômicosocial, conseqüência de hábitos e de princípios, do que de sangue e de clima, $e, e ́$ [sic] principalmente, como já tivemos oportunidade de dizer uma vez -é mais um mal de fome do que um mal de raça.

Para isso, Castro (1937) selecionou como interlocutores aqueles que, no âmbito da antropologia, da sociologia, da higiene, da geografia etc., tentavam retirar o preconceito de meio e de raça da discussão genética para a discussão cultural, apontando novos vilóes, entre outros, a dieta insuficiente, num momento em que as teorias raciais aqui assimiladas tornavam-se obsoletas. Assim, em coro com Roquette Pinto, Oliveira Viana, Alberto Torres, Gilberto Freyre, Afrânio Peixoto, Capistrano de Abreu, entre outros, refutava o determinismo geográfico de Ratzel e a doutrina racial de Goubineau, que influenciavam aqueles sociólogos brasileiros (não explicitados) envolvidos na sua divulgação, haja vista que:

A maioria, porém, cerrou fileiras em favor dos preconceitos de meio e de raça e quando falavam em meio, queriam se referir ao clima, acusado de assassino e, quando falavam de raça era para mostrar seu desdém pelas manchas inferiorizantes da mestiçagem. Para estes sociólogos pseudocientíficos, se o nosso povo produz pouco, se nossa organização econômica é falha e primitiva - é por culpa do clima maléfico - se nasce fraco, desenvolve-se mal e mantémse débil e raquítico - é por culpa da mistura racial, do caldeamento do branco com raças inferiores - o índio e o negro. Um bom procedimento de metermos na cabeça destes teimosos, que continuavam a dar valor científico aos artifícios decadentes de Goubineau - o homem das raças superiores e inferiores e aos continuadores das antigas lendas divulgadas na Europa, acerca dos mares efervescentes e areias em ebulição nas terras tropicais - será mostrar com documentos irrespondíveis, que os males que atacam o nosso povo também existem noutros países onde o clima não é tropical, onde, não se processou um caldeamento com a raça negra considerada inferiorizante. (Castro, 1937:116)

Segundo Thomas (1976) e Ortiz (1986), as teorias raciais elaboradas na Europa ocuparam espaço de relevo junto à elite intelectual brasileira entre 18881914. O determinismo biológico desenvolveu-se dentro de um sistema doutrinário científico no transcurso do século XVIII e XIX, com base em duas correntes teóricas fundamentais: o darwinismo social e o arianismo. O darwinismo social resultou da simplificação e adaptação sociológica da tese biológica de Darwin, sob a inspiração de Herbert Spencer (1820-1903). 
Nessa visão, a herança de cada indivíduo determinava, desde o seu nascimento, o seu destino social, desincumbindo-se a sociedade da sua responsabilidade. Com isso, a miscigenação passou a ter importância e se tornou objeto de debates em torno da noção de raça e diferenças raciais, eternizando uma série de mitos: o mito do sangue, o mito da cor, o mito judeu, entre outros. Mas os racistas foram além, estabelecendo hierarquias biológicas no interior da própria raça branca, constituindo o 'arianismo' como doutrina fundamental da superioridade racial. Foi Arthur de Goubineau quem formulou esse postulado em toda a sua plenitude, proclamando a superioridade da 'raça ariana' sobre as demais raças brancas. Suas idéias tiveram repercussão no pensamento filosófico e político da Europa, sendo logo divulgadas na Alemanha por Richard Wagner, afirmando-se também na França (Thomas, 1976). Segundo Da Matta (1991), para Goubineau, havia uma perfeita equação entre características biológicas, psicológicas e posição histórica.

Quanto a isso, tal teoria permitia relacionar a biologia e a história com a moralidade, realçando classificatoriamente as potencialidades e tendências raciais. Para Ortiz (1986), a publicação de Goubineau (Essais sur les Inégalités des Races Humaines), em 1853-1855, coincidia com o momento em que tomavam vulto as idéias a respeito da evolução social e seu vínculo imediato com as premissas raciais, ao tempo em que se desenvolviam técnicas de medidas cranianas, que se legitimavam com a criação da primeira Sociedade de Antropologia de Paris, em 1859, por Pierre Broca, especialista nesse ramo.

Como acentua Comas (1970), a antropologia física se constituía como um instrumento de aperfeiçoamento da doutrina de Goubineau sob a ótica da classificação e seleção social em que a conformação do crânio foi ponto importante, visto que determinava a forma do cérebro e o correspondente tipo psicológico. Não obstante as contradições evidenciadas entre tais teorias, elas serviram de quadro de referência ao desenvolvimento do nazismo e do fascismo contemporâneo, que postulavam a unidade nacional pela unidade da raça. A doutrina de Goubineau foi aceita no Brasil, onde ele marcou passagem como amigo do Imperador D. Pedro II. Do arianismo, os brasileiros endossaram a teoria da degenerescência latina (traduzida nas críticas aos portugueses como os mais atrasados dos europeus) resultante da indolência e da imoralidade. Coincidentemente, a antropologia física foi uma das primeiras disciplinas reconhecidas em virtude de importantes expedições feitas por cientistas estrangeiros, freqüentemente alemães. Em 1876, foi fundado no Rio de Janeiro um laboratório de fisiologia experimental, em conexão com o Museu Nacional, no qual se organizou uma Exposição Antropológica Brasileira, em 1882, concentrada no índio. 
Nesse aspecto, é importante assinalar a estreita aproximação entre esse campo e a medicina em toda a trajetória em que esteve em debate no Brasil a questão racial. A título de ilustração, segundo Thomas (1976), o primeiro estudo de impacto foi o de Nina Rodrigues, professor de medicina-legal e principal doutrinador racista do fim do século passado.

Nesse sentido, a formulação da tese 'mal de fome e não de raça' trazia em seu âmbito questões que remetem à análise dos elementos de continuidade e rupturas que, no período de 1934 a 1939, marcaram os contornos da base cognitiva deste campo: primeiro, em relação ao senso comum - o discurso científico do preconceito racial e do meio -, que via na inferioridade racial decorrente da mestiçagem a explicação do porquê do atraso nacional; segundo, em relação à multiplicidade de métodos que se confundiam com a multiplicidade de perspectivas que o problema alimentar apresentava. Isso se constituía, afinal, no principal obstáculo ao estudo científico da alimentação, pois, como aponta Castro (1937:22): "Já Dartre dissera que o problema alimentar é sem dúvida culinário e gastronômico, mas é também econômico e social, agrícola, fiscal, higiênico, médico e mesmo moral. E principalmente e antes de tudo fisiológico".

Assim, o objeto sobre o qual se projetavam as análises estava em vários domínios: da biologia, da antropologia física e cultural, da etnografia, da patologia, da economia política, da sociologia, da higiene e da história. Era pela intersecção do método fisiológico com o método geográfico que a educação alimentar ia-se diferenciando desses múltiplos campos, embora preservasse a perspectiva interdisciplinar na delimitação de fronteiras pelas quais ia se constituindo.

Nas palavras de Castro (1937), para ser estabelecida uma alimentação racional fundada em princípios científicos, para uma eficaz atividade produtiva de um povo, numa região, era preciso, de um lado, haver estudos aprofundados de fisiologia da nutrição, dos caracteres físicos e morais do povo dessa região, de sua evolução demográfica, de sua capacidade e resistência orgânicas e, de outro lado, haver o estudo das condições físicas do meio, das suas condições econômicas, da organização social e dos gêneros de vida de seus habitantes. Assim, o único método capaz de viabilizar uma análise da questão alimentar em suas várias faces era o método da geografia nova de Vidal de La Blache, ${ }^{11}$ cujo princípio de conexidade permitia estudar esse fenômeno como um fator de evolução social ao lado de outros fatores aos quais estavam ligados, por conexão do meio, por influências mútuas:

${ }^{11}$ A partir desse ponto, adotar-se-á La Blache sempre que for necessário se reportar ao método geográfico de Vidal de La Blache, embora a literatura empregue variadas designações: geografia lablachiana, geografia vidaliana ou, simplesmente, Vidal. 
Só a geografia que ensina a saber ver os fenômenos que se passam em sua superfície, a observá-los, tendo em vista a sua localização, extensão e causalidade, pode orientar o espírito humano na análise do vasto problema de alimentação, como um fenômeno ligado, através de influências recíprocas, à ação do homem, do solo, do clima, da vegetação e do horizonte de trabalho. (Castro, 1937:26)

A tese 'mal de fome e não de raça', traduzida no âmbito do método geográfico, vinha não apenas estabelecer uma ruptura com o preconceito de meio e de raça, mas fornecia também à geografia nova que se institucionalizava no Brasil, sob influência da geografia francesa, novos elementos cognitivos. É digno de nota que foi com a fundação dos cursos de geografia em nível universitário (1934) e com a criação do Conselho Nacional de Geografia (1937) que se iniciou a fase moderna da geografia por aqui.

Nesse aspecto, a geografia nova, em seus primórdios, dividia espaços com a história, a antropologia, a sociologia e, até mesmo, com a higiene. Embora a literatura não seja tão clara a esse respeito, vale destacar, a título de ilustração, alguns dos muitos pioneiros desse campo, que se constituíram em interlocutores no interior da produção da ciência da nutrição/educação alimentar:

- Capistrano de Abreu, historiador e verdadeiro conhecedor e difusor das doutrinas de Ratzel. Suas obras mais importantes foram: Capítulos da História Colonial e Caminhos Antigos e Povoamento do Brasil, em que substituía o conceito de raça pelo de cultura, refletindo, assim, a mudança no pensamento antropológico que triunfou nos Estados Unidos e na Europa entre 1900 e 1930;

- Euclides da Cunha, que reuniu em Os Sertōes doutrinas de Ratzel, Humboldt, sendo considerado o precursor da geografia, publicando também a obra Terra sem História, em que figurava conhecimento da geografia moderna referente à época em que viveu (1866-1909). O autor precedeu ao conceito lablachiano de 'gêneros de vida', aparecido em 1911;

- Henrique Morize (1891), que apresentou uma classificação climática, com a publicação da obra Contribuição ao Estudo do Clima no Brasil.

Outros autores que publicaram obras de interesse para a geografia econômica e social, sob a influência francesa da geografia humana:

- Alberto Torres (1914), em cujos livros rejeitava o quadro de referência das doutrinas inatas entre as raças, afirmando, segundo Thomas (1976), que a unidade nacional era de natureza sociológica, e não racial;

- Afrânio Peixoto, médico, publicou, entre outras obras, Minha Terra minha Gente (1916), primeiro manual escolar a enfrentar o problema da raça e do clima, e, já em 3a edição, Higiene (1930); 
- Roquette Pinto, antropólogo, seguidor de Alberto Torres e crítico de Euclides da Cunha, cujas obras contribuíram para difundir no Brasil a teoria da cultura que começava a se tornar, nos anos 20, tanto na Europa como nos Estados Unidos, a chave da ciência social do meio ambiente. Destacam-se, desse autor, as obras: Rondônia (1916), Ensaios de Antropologia Braziliana (1933) e Seixos Rolados.

Mas foi a obra de Raimundo Lopes, Torrão Maranhense, que constituiu o melhor trabalho sobre geografia. Na década de 30 , o ponto alto da geografia humana foi dado por Oliveira Viana, que escreveu sobre a Evolução do Povo Brasileiro e Populações Meridionais, estudo histórico no qual tentava aplicar as doutrinas da antropogeografia e da antropossociologia, em que oferecia prova empírica da ascensão do Brasil para a branquitude, publicando também Raças e Assimilação, em 1933.

Para Thomas (1976), esse autor serviu como ponte entre o racismo científico predominante antes de 1914 e a filosofia social de fundo 'ambientalista', predominante depois de 30 . Assim, até o terceiro decênio do século XX, as investigações de caráter geográfico, sem método seguro e objetivo específico, se processavam nas instituições ou nos organismos técnico-administrativos, oficiais ou particulares que, desde a Comissão Geológica do Império até o advento do Conselho Nacional de Geografia, foram fundados para atender aos imperativos do desenvolvimento econômico (Azevedo, s/d; Thomas, 1976).

A implantação, em 1931, do sistema universitário, condicionado pelo estatuto das universidades brasileiras, pondo em equação e solucionando o problema da formação técnica e científica dos futuros mestres e pesquisadores, vinha resolver o caso da formação dos geógrafos e professores de geografia do País. À Faculdade de Filosofia, Ciências e Letras da Universidade de São Paulo, fundada em 1934, coube iniciar a missão de preparar professores de geografia para a pesquisa de campo, sendo a pioneira e, historicamente, a maior responsável pelo desenvolvimento das investigações e estudos geográficos na fase contemporânea, sob a orientação de pesquisadores e especialistas externos, principalmente franceses, que transmitiram a cultura geográfica dos seus países (Azevedo, s/d).

$\mathrm{Na}$ perspectiva de articulação entre natureza e sociedade, a geografia trouxe a maior contribuição para a constituição da educação alimentar, embora não seja visível uma unanimidade entre os intelectuais na adoção do conceito geográfico. Em torno da tese 'mal de fome e não de raça' articularam-se todos os explicadores da questão alimentar brasileira. 
Quanto a isso, o livro de Messias do Carmo (1937), Política Alimentar Brasileira, avançava na compreensão de que a demonstração da tese 'mal de fome e não de raça' resumia não apenas a dimensão causal da questão alimentar, mas também uma dimensão finalista e, por conseqüência, política. Ao reiterar essa tese, o autor afirmava que pelo menos dois fatos estavam inteiramente provados:

- quase todo europeu podia viver, prosperar e transmitir sua capacidade de trabalho e inteligência nas regiões tropicais;

- o homem cruzado, o mestiço, não era sinônimo de inferioridade, pois, segundo ele, como afirmava Alberto Torres, todo homem era um ser em que o fenômeno da vida reunia as condições e propriedades complexas de adaptabilidade. Neste aspecto, uma das dimensões finalistas estava, a priori, não na definição do tipo racial puro (dado que, no Brasil, segundo Carmo, somos todos mestiços), mas na definição do homem médio como resultado de cruzamentos que viabilizaram a formação étnica brasileira em determinado quadro demográfico.

Disso se depreende que, embora os anos 30 não comportassem mais o debate racial nos moldes antigos, pois já se afirmava o valor do mestiço (Thomas, 1976; Ortiz, 1986), parecia comportar a questão sobre a definição do perfil biofísico do brasileiro em outras bases: a fisiologia da nutrição. Na obra de Oliveira Viana, Raças e Assimilação, de 1933, Carmo (1937) identificou o coeficiente de crescimento regional do Brasil e na obra de Roquette Pinto, Ensaios de Antropologia Brasiliana, também de 1933, encontrou a classificação dos tipos humanos que compunham os diversos quadros demográficos. Com isso, chegava a outra dimensão finalista da tese 'mal de fome e não de raça', voltandose para a determinação do tipo médio de alimentação racional exigida pelo homem local, à luz do método fisiológico na perspectiva da definição de uma política alimentar para o País. Para tal, o uso do método geográfico era necessário, pois as evidências mostravam que não havia um regime normal, mas regimes normais, a considerar, de um lado, os caracteres somáticos fisiológicos, como: raça, idade, sexo, crescimento, desgaste físico ou intelectual e, de outro, os atinentes à antropogeografia nos seus elementos ecológicos e de civilização: clima, produção, meio social, tradições etc.

Recorrendo aos ensinamentos da geografia física de Henrique Morize e da geografia botânica de J. A. Sampaio, Carmo (1937) apontava, a exemplo de Castro, as possibilidades que o meio territorial brasileiro oferecia ao homem em seu processo de adaptação, concluindo que o clima local era favorável em três aspectos: agrícola, higiênico e social. 
Nos anos 30, a sociedade brasileira se voltava para a perspectiva da consolidação de demandas e mudanças sociais, políticas, econômicas e culturais, comprometidas com a reorientação dos rumos do País, momento em que um novo Estado se reorganizava e assumia a tarefa de orientar o próprio desenvolvimento social. Dentro deste quadro, as teorias raciais precisavam ser superadas, pois a realidade social impunha outro tipo de interpretação do Brasil:

A ambigüidade da identidade do Ser nacional forjada pelos intelectuais do século XIX não podia resistir mais tempo. Ela havia se tornado incompatível com o processo de desenvolvimento econômico-social do país. Basta lembrarmos que nos anos 30 procura-se transformar radicalmente o conceito de homem brasileiro. Qualidades como 'indolência' e 'preguiça', consideradas como atributo da raça mestiça, eram substituídas pela ideologia do trabalho (...). O que se assiste neste momento é na verdade uma transformação cultural profunda, pois se busca adequar as mentalidades às novas exigências de um Brasil 'moderno'. (Ortiz, 1986:42-45)

É por essa ótica que se lança luz no entendimento do processo de gênese e constituição da educação alimentar, pois será visto neste estudo que, em última instância, em nível de justificação, as variantes explicativas desenvolvidas pelos intelectuais, no conjunto da produção pioneira desse campo, convergiam para a definição de um novo perfil biofísico do homem brasileiro, apreendido nos meandros do trabalho e da produtividade.

Coutinho (1937:194), no livro Valor Social da Alimentação, demonstrava, por uma síntese teórica e pelo inquérito que realizou com escolares do Rio de Janeiro, que era o valor biológico da dieta o principal determinante da eficiência de um grupo social e não o clima e as características raciais:

São grupos sociais esses, das regiões tropicais, assim subalimentados que se mostram inertes, preguiçosos, incapazes, sem avanço na civilização, o que muitos consideram prova da inferioridade dessas raças, que não são brancas puras, assim como prova da nocividade dos climas quentes.

Nesse ponto, o autor, a exemplo de Castro, refutava a tese da inferioridade da raça assimilada no Brasil, a partir da publicação do livro de Goubineau. Para ele, o que os arianistas atribuíam à raça era, em grande parte, simples conseqüência do ambiente, logo, resultado de fatores socioculturais.

De fato, os intelectuais em foco, ao rejeitarem o quadro de referência de Goubineau, explicitando a tese 'mal de fome e não de raça', aproximavam-se da escola culturalista de pensamento que emergia na última década do século passado, com Franz Boas, professor de antropologia da Columbia University, e ganhava expressão nas primeiras décadas do século 20 no Brasil, com Gilberto 
Freyre, seu discípulo. Vale salientar que emergia, neste período, a escola sociológica durkheimiana (1896), que viria a influenciar significativamente o pensamento antropológico, dado que a sua visão de sociedade, como fato sui generis, orientava o estudo do social em bases radicalmente diferentes da problemática das raçase do meio (Ortiz, 1986). Assim, a antropologia física cedia lugar à antropologia cultural, que estabelecia o meio ambiente como o fator mais importante na evolução social, redefinindo o estatuto desse campo. Sendo Freyre uma das figuras de maior projeção deste pensamento, no Brasil, transformou-se em referência precursora obrigatória no conjunto dos estudos sobre alimentação. ${ }^{12}$

A passagem do conceito de raça para o de cultura suprimia uma série de dificuldades colocadas anteriormente a respeito da herança do mestiço. No entanto, ela permitia ainda um maior distanciamento entre o biológico e o social, o que possibilitava uma análise mais rica da sociedade. Se esta teoria do valor cultural se afastava do biológico, fornecendo aos intelectuais elementos para a justificação da tese 'mal de fome e não de raça', estes, ao produzirem a base cognitiva do campo da ciência da nutrição e, no seu âmbito, a educação alimentar, reconstituíam o biológico como um fator de evolução social em novas bases.

Mendonça (1938), no livro Noções Práticas de Alimentação, realçava a abordagem dos princípios fisiológicos como ponto de partida da investigação em alimentação, reiterando, no capítulo 'Alimentação e Constituição', a tese 'mal de fome e não de raça'. Ele afirmava que, sendo o biotipo determinado pelo conjunto de fatores intrínsecos inerentes ao indivíduo e de fatores extrínsecos dependentes do meio ambiente, era a alimentação o fator extrínseco mais importante na constituição do biotipo humano, desde o momento da sua concepção, e não o clima e a raça. Disso se depreende que, se a doutrina racial de Goubineau não possuía um estatuto de ciência e, além disso, estava fora do lugar, pois eram todos mestiços e não cabia a definição do tipo racial puro entre a população daqui, era pela alimentação que se fazia a valorização eugênica do homem e o aperfeiçoamento da raça.

O que estava em questão era o aperfeiçoamento do conceito de eugenia, em que o alimento se configurava como elemento biológico fundamental. Contudo, sendo o alimento um elemento externo da maior significação, ele não tinha apenas um valor biológico, mas também cultural, e só poderia ser concebido como elemento de aperfeiçoamento racial sob as modificações do complexo ecológico à luz do método geográfico. Sendo o Brasil um país de extenso território, com regiões de climas diferentes, não poderia ter um tipo uniforme de alimentação.

${ }^{12}$ A respeito da obra de Freyre, ver: Mota (1994) e OrLANDI (1993). 
Embora de forma menos elaborada, Botelho (1938), em seu livro Os Pequenos Fundamentos da Bôa Alimentação, assinalava também que a degeneração racial estava na subalimentação do povo. A noção de região era necessária para conhecer a alimentação habitual do País, sob a premissa de que, dentro de cada região, havia uma uniformidade básica alimentar, com pratos alimentares absolutamente característicos para cada estado. Esse autor concebia a região como uma unidade autônoma.

Nesse aspecto, La Blache (1936), ao reagir à tese determinista de Ratzel (segundo a qual os dados naturais exercem influência direta e determinante sobre os fatos humanos), considerou de importância vital a história para avaliar as diversas maneiras pelas quais os homens estão em relação aos fatos físicos. Ele introduziu a noção das descrições aprofundadas como a forma mais acabada do pensamento geográfico. As paisagens de uma dada região eram o resultado da superposição, ao longo da história, das influências humanas e dos dados naturais (Lacoste, 1988). Para o autor, La Blache deu maior peso às 'permanências', a tudo o que era herança duradoura dos fenômenos naturais ou de evoluções históricas antigas, alijando das suas descrições tudo que decorria da evolução econômica e social recente, tudo o que tinha menos de um século e traduzia os efeitos da Revolução Industrial:

Vidal de La Blache instala (com que estilo!) sua concepção de 'Homem-habitante' e essa expulsa para fora dos limites da reflexão geográfica o homem nas suas relações sociais, e com mais forte razão ainda, nas relações de produção. Além do mais, o 'homem vidaliano' não habita as cidades, ele mora sobretudo no campo, ele é sobretudo o habitante de paisagens que seus ancestrais longínquos modelaram e organizaram. (Lacoste, 1988:61)

Vale ressaltar que houve, de fato, como será visto no decorrer desse estudo, uma tendência compartilhada entre os intelectuais que fizeram uso do método geográfico, ao darem maior ênfase às características e descrições do problema alimentar como expressão regional de uma herança histórico-socialcolonial, modelada e organizada pelos ancestrais, que se perpetuava no nível dos hábitos alimentares erroneamente constituídos. Nesse enfoque, a região foi concebida como uma unidade organizacional autônoma, mas estendida ao nacional sem as devidas mediações. O nacional era, em si, a soma dos defeitos e virtudes regionais.

Embora a maioria dos intelectuais tenha adotado a trilha aberta por Castro, quanto ao uso do método geográfico, preservando a fisiologia como ponto de partida na demonstração dessa tese, houve também uma tendência centrada no enfoque individual na construção da racionalidade alimentar. 
Afastando-se do método geográfico, Costa (1938), em seu livro Bases da Alimentação Racional, centrou seu estudo no indivíduo, reiterando, ainda que implicitamente, a tese 'mal de fome e não de raça'. Nesse enfoque, o povo era a soma total dos defeitos e virtudes que se encontrava em cada indivíduo. E, se era formado por indivíduos desnutridos e subalimentados, seria um povo de valor reduzido e de experiência inferior às suas possibilidades: "Hoje, é fato absolutamente provado, a alimentação influi no desenvolvimento dos grupos sociais, traçandolhes o destino. A conquista do poderio econômico, político, moral, material está reservada aos povos que se nutrem melhor" (Costa, 1938:219).

Com isso, o autor queria dizer também que era pela alimentação que se fazia a valorização eugênica do indivíduo e, por extensão, o aperfeiçoamento racial. Não era preocupação desse autor o dimensionamento do instrumental de investigação coletiva do problema alimentar, tampouco a descrição geográfica desse fenômeno. O valor sociocultural da alimentação, inclusive a sua evolução no processo civilizatório, era uma noção que perpassava abstratamente a argumentação em que se acentuavam as dimensões fisiológicas do indivíduo e o valor biológico do alimento como elemento externo definidor do biotipo brasileiro - o homem médio. Este homem, somado a milhões e milhões de outros, constituía um povo, a nação, um grupo social. Assim, adquiria importância, no processo de gênese e constituição da educação alimentar, o indivíduo nas várias fases da vida: a criança, o adulto, o velho. Coerentemente, ganhava expressão, nesta visão, o enfoque técnico no lançamento das bases da alimentação racional, à luz das variáveis fisiológicas (idade, sexo, atividade etc.), situando variáveis sociais, como custo da alimentação e produção de alimentos como problemas do domínio do indivíduo que, utilizando o quintal da casa, poderia cultivar hortas e desenvolver a criação de animais. Assim, tal abordagem difere significativamente da maioria do conjunto da produção que usou o método geográfico, visto que o proceder explicativo esteve à margem das características da organização social brasileira, o que remete à questão das causalidades e das finalidades para o âmbito individual. Desse modo, a conexão entre o biológico e o social se dava no plano da abstração.

Aproximando-se de Costa, Moscoso (1939), em seu livro Alimentação do Trabalhador, centrou sua atenção na determinação das bases científicas da alimentação do indivíduo. Reiterando a tese 'mal de fome e não de raça', ele afirmava que a indolência e a falta de aptidão para o trabalho não tinha como causa o clima e a raça, mas uma alimentação inadequada e insuficiente, que não dava vigor para o trabalho nem defesa para a doença. A variante 'trabalho' adquiria importância como uma dimensão fisiológica do trabalhador, 
desconectada do modo de organização social do trabalho, embora esse autor possa ser considerado o idealizador de um plano de política alimentar para o trabalhador. Nesse enfoque, era a unidade familiar que adquiria expressão como somatório de demandas e possibilidades de cada indivíduo. Quanto a isso, o estudo se volta para a determinação de uma ração-tipo concebida como uma unidade de alimentação.

O que unia os intelectuais em torno da formulação da tese 'mal de fome e não de raça' na decodificação do problema da fome/subalimentação, nos anos de 1934 a 1939, era a perspectiva do aperfeiçoamento do conceito de eugenia como um fator de evolução social de fundo ambientalista, à luz de dois modelos explicativos diferentes: o método geográfico, pelo qual se chegava à conexão entre o biológico e o social, dimensionando o coletivo como meta, e o método fisiológico, pelo qual a conexão entre o biológico e o social foi abstraída no indivíduo. Da condição de degenerado e irresponsável, na visão dos adeptos do arianismo, o mestiço tinha o seu papel reconhecido na formação e no desenvolvimento social brasileiros, não sendo mais um elemento de atraso, mas um elemento capaz de criar a civilização, na medida em que suplantava os conflitos e resistia ao clima e às condições hostis, adquirindo um novo perfil biofísico de homem médio, sob a marca da robustez, da vitalidade e da eficiência, por um processo de revitalização alimentar feita em bases científicas, racionais.

Vale salientar que o conceito de eugenia, que se foi constituindo a partir do movimento higienista dos anos 20 , já se cristalizara na Constituição de 1934 e se reafirmava na Constituição de 1937, quando se estabelecia uma política de controle da entrada de estrangeiros no País, bem como a educação higiênica relacionada aos atributos físicos do novo homem que se configurava em prioridade nacional. Como bem assinalava Carmo (1937:40-42), no livro Política Alimentar Brasileira,

Não será possível pretender leis que permitam a esterilização dos tarados, dos portadores de herança mórbida ou criminal (...) está fora de dúvida, e não comporta mais discussão teórica a necessidade urgentíssima da obrigatoriedade do exame pré-nupcial e da intensificação de uma campanha enérgica de combate à sífilis e à subalimentação, pois, estas três medidas formam a tripeça de um movimento eugênico pelo alevantamento racial.

O entendimento das características do conjunto da produção em foco, no processo de gênese e constituição da educação alimentar, passa, também, pela explicitação das variáveis analíticas que permearam a aplicação do método geográfico e fisiológico em que era traduzida a fome/subalimentação. 


\section{A dimensão fisiológica da alimentação racional: o homem (máquina) e o alimento (combustível)}

A dimensão fisiológica da alimentação se constituiu em categoria analítica fundamental no processo de caracterização do objeto da ciência da nutrição e, no seu âmbito, a educação alimentar. Como parte da arquitetura do método explicativo, a fisiologia era o ponto de partida para a investigação alimentar e pré-requisito para a construção das bases científicas do conceito de racionalidade alimentar, na perspectiva da afirmação do valor social da alimentação e do aperfeiçoamento do conceito de eugenia. Trata-se, então, de reconstituir, neste tópico, a base cognitiva justificadora da configuração da dietética como núcleo instrumental na elaboração do modelo-padrão da alimentação racional a ser incorporado pela educação.

Tal evidência pode ser destacada a partir da obra de Castro (1934), O Problema da Alimentação no Brasil, que trazia como proposição central uma síntese das noções básicas da fisiologia de modo a indicar os elementos científicos necessários à composição da alimentação racional. Ao trabalhar com a idéia de noções, o autor indicava que um conceito de racionalidade alimentar estava em processo de construção, o que fez desse ano o marco da gênese da educação alimentar. Nesse enfoque,

O conhecimento da constituição físico-química da matéria viva, do seu equilíbrio dinâmico, dos seus gastos e necessidades vitais, do conceito geral de nutrição - o estudo enfim do metabolismo orgânico - é o ponto de partida para a investigação da alimentação. (Castro, 1934:9)

O primeiro postulado científico do conceito de racionalidade alimentar, a ser incorporado pela educação, estava na evidência de que o antecedente do fenômeno vital era sempre um fenômeno químico e que a energia potencial dos alimentos era a primeira fase do sistema de transformações que sofria a energia no organismo vivo. Era possível prever as variações desses fenômenos, orientare modificar sua marcha de acordo com as necessidades individuais e o máximo de rendimento vital à luz do estudo da bioenergética, de acordo com as variações que as condições climatéricas imprimiam ao habitante dos trópicos. O clima se constituía, então, como primeiro elemento a compor a noção de meio geográfico nos estudos sobre alimentação.

Como será visto, um dado fundamental está em evidência no período de 1934 a 1939: a existência de uma produção articulada em torno da obrigação de determinar, previamente, o normal e seus verdadeiros limites de variação, enquanto explorava a natureza e os efeitos da fome e da subalimentação, 
colocando a fisiologia como condição obrigatória para chegar à determinação da alimentação racional, constituindo o conceito de racionalidade alimentar.

Para estabelecer a composição precisa de um regime alimentar que pusesse o organismo em estado de equilibrio, era preciso calcular, de um lado, as despesas do organismo vivo e, do outro, o potencial energético dos alimentos sob métodos especiais. As despesas do organismo podiam ser calculadas em virtude do metabolismo basal e do metabolismo de trabalho, considerando também o metabolismo da digestão e as variações em razão da idade, sexo, constituição corporal, estado de alimentação e o clima (Castro, 1934).

Segundo esse autor, os estudos desenvolvidos por Lusk, em 1929, e Dubois, Bennedict e Bootlhy, em 1924, constatavam que a constituição individual, o peso, a idade, o estado de alimentação e os agentes físicos do meio nos limites fisiológicos não alteravam as cifras dos gastos energéticos fundamentais, tomando por referência a constante fisiológica de 39,7 calorias com variação em torno de aproximadamente $10 \%$, estabelecida por Dubois. No entanto, Castro (1934) observava que Almeida, ao determinar, em 1919, as medidas do metabolismo basal em 20 pessoas do Rio de Janeiro, encontrou cifra inferior a 20,4\% (31,6 calorias), comparada com o padrão americano. A explicação para tal fenômeno estava no clima que, segundo ele, era a tradução fisiológica de uma condição geográfica, como já definira Euclides da Cunha. A aclimatação era o recurso de que o organismo lançava mão para conservar íntegros seus atributos vitais.

A fim de documentar suas conclusões sobre o modo como o clima interagia com a fisiologia do homem dos trópicos, Castro (1934) procedeu à determinação do metabolismo basal de 15 habitantes de Recife (PE), adotando a definição indicada por Lusk e Bennedict, segundo a qual o metabolismo mínimo correspondia à quantidade mínima de calor usada pelo animal na manutenção das funções vitais básicas, em repouso absoluto, jejum e estado de neutralidade térmica. O quociente desta cifra energética produzida durante uma hora pela superfície cutânea do animal representava o metabolismo basal. A partir da cifra média de 34,6 calorias obtida em seu estudo, o mencionado autor definiu que o metabolismo basal dos habitantes do Brasil era de $10 \%$ a $30 \%$ menor do que o dos habitantes dos climas frios e temperados ou dos climas quentes, considerando a constante fisiológica padrão de Dubois, 39,7 calorias. Ficava posta a primeira indicação para a determinação da quota de energia da ração alimentar, usando, para isso, as tabelas de Bennedict e Harris para os habitantes da América do Norte, tendo o cuidado de descontar da cifra total encontrada uma porcentagem em média de $15 \%$, o que equivaleria a 33,8 calorias para o homem local. 
Nesse enfoque, o segundo elemento do meio que interagia com o metabolismo orgânico do homem era o trabalho, o que implicava a necessidade de calcular a adicional energética referente às várias ocupações habituais, representadas em calorias despendidas por hora em determinadas atividades de homens e mulheres. A esse respeito, Castro (1934) indicava o uso da tabela padrão de Lusk, publicada em 1929, por considerá-la o estudo mais sistematizado sobre a categoria trabalho. Além disso, outro elemento importante, segundo o autor, era a ação dinâmico-específica do alimento que, na acepção de Rubner, correspondia à transformação que o alimento sofria depois de absorvido para a sua utilização fisiológica como verdadeiro 'combustível'. Num regime misto, a escola americana de Mclester estabeleceu, em 1929, um acréscimo de 10\% ao metabolismo basal somado ao metabolismo de trabalho em consonância com a cifra já fixada por Sherman em 1923.

Com essa equação bioenergética, Castro (1934) chegava a uma primeira definição do biotipo médio brasileiro com idade de 40 anos, pesando $60 \mathrm{~kg}$, com 1,62 m de altura, sapateiro, trabalhando oito horas por dia, que gastava 2.769 calorias diárias, considerando a técnica de cálculo de Dubois: 1.217 calorias de metabolismo basal, mais 720 calorias de energia gasta no trabalho de sapateiro, mais 520 calorias de energia suplementar de repouso relativo às horas não trabalhadas, o que era igual a $30 \%$ sobre o total de energia de trabalho de base, e 251 calorias de energia gastas na ação dinâmico-específica da alimentação, que era igual a $10 \%$ sobre o total das outras energias gastas.

Será visto, adiante, como os intelectuais compartilharam do uso das expressões 'homem-máquina' e 'alimento-combustível' nos estudos fisiológicos da alimentação, nos quais passaram a ganhar ênfase as expressões 'homemcapital' e 'receita-despesa'. Se o conceito cartesiano de máquina viva fornecia elementos para o conhecimento das despesas energéticas do homem brasileiro, o alimento era a fonte das receitas orgânicas e elemento de interação entre o homem e o ambiente. O conhecimento da sua composição química e suas funções fisiológicas permitia classificá-los em: alimentos energéticos, alimentos plásticos e alimentos reguladores. O valor energético era de ordem quantitativa e se encontrava nos alimentos ricos em hidratos de carbono e nas gorduras. $O$ valor plástico e regulador era de ordem qualitativa e se encontrava nos alimentos ricos em proteínas e vitaminas/minerais, respectivamente.

Assim, o valor termoquímico dos alimentos, como medida do calor de combustão realizada na bomba calorimétrica de Bertholot, dava as seguintes cifras em calorias, segundo Castro (1934): 1 g de proteína continha 4,1 calorias, $1 \mathrm{~g}$ de gordura continha 9,3 calorias, e $1 \mathrm{~g}$ de hidratos de carbono continha 
4,1 calorias. A ração energética do homem que executava trabalho mediano no clima característico local devia fornecer as seguintes proporções desses elementos: $20 \%$ a $30 \%$ do total de calorias em matérias protéicas, o que equivalia a $1 \mathrm{~g}$ de proteína por quilo de peso do indivíduo adulto; $20 \%$ a $30 \%$ em gorduras e os $50 \%$ restantes em hidratos de carbono. Para uso, no Brasil, esse autor recomendava duas tábuas de composição de alimentos que foram inclusive muito utilizadas no conjunto das obras em análise. Uma, elaborada em 1922 pelo dr. Alfredo A. de Andrade, quando diretor do Laboratório Bromatológico de Saúde Pública; outra, apresentada em 1933 pela Comissão de Médicos Militares, encarregada da organização de dietas. Com isso, ele chegava à segunda indicação para a determinação da ração alimentar racional.

No entanto, foi no livro A Alimentação Brasileira à Luz da Geografia Humana que Castro (1937) chegou a uma definição de nutrição como processo e as respectivas fases que deveriam compor o seu estudo fisiológico: digestão, absorção, utilização, desassimilação e excreção das substâncias alimentares. Segundo ele,

A nutrição é o total de processos por meio dos quais os sêres vivos recebem e utilizam as matérias exteriores necessárias à manutenção da vida. $\mathrm{Na}$ realidade, os fenômenos vitais não são efeitos de uma atividade puramente interna; são, ao contrário, resultante de uma ação recíproca entre a matéria viva e o ambiente, donde as duas condições essenciais de vida, uma interna, que é a organização celular e outra externa, que é a existência de um meio conveniente. (Castro, 1937:32)

Nesse aspecto, para Castro (1937:47), a velha definição de clima incluía todos os agentes naturais exteriores. No entanto, a concepção moderna de Ratzel, ao reagir contra a amplitude da noção antiga, acabava por se tornar excessivamente restrita, dado que limitava a categoria de clima "às influências que derivam das propriedades sensiveis do ar, isto é, do calor e do frio, da umidade e da secura, e de como se apresentam distribuídas e combinadas estas propriedades". Segundo ele, definições mais completas de clima foram indicadas por Julias Hann e outros pesquisadores, que o definiam como a súmula dos fenômenos meteorológicos que caracterizavam a média da atmosfera em qualquer lugar da superfície terrestre. Dentre esses fenômenos, destacavam-se por sua importância: a temperatura, a umidade relativa e a velocidade do ar.

Desse modo, para Castro (1937), os climogramas constituídos por Taylor e aperfeiçoados por Henrique Morize exprimiam as verdadeiras características de um clima em relação ao homem. Segundo ele, a classificação dos climas brasileiros feita por Morize indicava três grandes grupos: clima equatorial (temperatura anual de $25^{\circ}$ ); clima subtropical (temperatura média anual em 
torno de $20^{\circ}$ e $25^{\circ}$ ); clima temperado brando (temperatura média anual entre $10^{\circ}$ e $20^{\circ}$. No entanto, Castro achava que esta classificação baseava-se exclusivamente na temperatura bruta e, se se tomassem as diversas localidades e zonas e aplicasse a técnica de Taylor, o resultado seria um clima quente e úmido.

Assim, a diminuição do metabolismo de base nos climas tropicais não era proporcional apenas à temperatura bruta, mas, também, à umidade relativa. Castro (1937) estendeu à cidade de Rio Branco, bem como à cidade de Nazaré, em Pernambuco, as determinações do metabolismo basal realizadas com habitantes de Recife (1934), encontrando cifras de 36,2 calorias e 32,7 calorias nas duas cidades, respectivamente. Comparando com a cifra encontrada em Recife (34,6 calorias), esse autor atribuiu a diferença desses resultados à diversidade da umidade relativa no clima das três cidades, já que detinham a mesma temperatura média. Isso, em vez de ser traduzido como expressão de uma manifestação patológica, realçava a expressão de uma verdadeira adaptação do organismo humano às temperaturas elevadas.

Castro (1937) aprimorava, nessa obra, os postulados fisiológicos desenvolvidos sobre o metabolismo basal e chegava a uma definição classificatória da categoria trabalho na determinação das despesas energéticas do homem brasileiro. Considerando que inexistiam no Brasil estudos sistematizados sobre o metabolismo de trabalho, ele adotou de maneira empírica a classificação de atividades do Comitê Interaliado de Alimentação. Nesse aspecto, quatro categorias de atividades foram delineadas como orientação ao cálculo da ração energética: trabalho sedentário (intelectual, alfaiate); trabalho leve (sapateiro, encadernador); trabalho moderado (pintor, carpinteiro); e trabalho pesado (ferreiro, serrador de madeira). Em sua conclusão, ele reafirmava o cálculo de 2.800 calorias como padrão médio da quota diária do homem tropical médio brasileiro, alertando que não bastava para que a ração alimentar fosse 'perfeita' que ela contivesse o total energético necessário às despesas do organismo. Era preciso que esta ração fosse formada por quantidades satisfatórias, em determinadas proporções mútuas, das várias espécies de alimentos: proteínas, gorduras, hidratos de carbono, vitaminas, minerais e água.

Com isso, estavam lançadas por Castro (1937), ao estilo de Escudero (1934), as quatro 'Leis da Alimentação': quantidade, qualidade, harmonia e adequação. Ao definir tais parâmetros de normatividade, o autor prenunciava quatro convenções particulares da linguagem científica na construção do conceito de racionalidade alimentar, às quais iam constituindo, no período em foco, a dietética como núcleo instrumental fundamental, pelo qual se configuravam a ciência da nutrição e suas diversas ramificações disciplinares, inclusive a educação 
alimentar. Era por referência a uma ração normal (média) que os intelectuais chegariam à demonstração da tese 'mal de fome e não de raça', decifrando os contornos biossociais da fome/subalimentação.

Assim, a categoria 'clima' adquiriu expressão nos estudos fisiológicos sobre alimentação. Coutinho (1937), no livro Valor Social da Alimentação, procedeu extensa revisão teórica pela qual trazia à discussão variada gama de fontes bibliográficas americanas e européias que informavam resultados de pesquisas experimentais e ensaios de campo sobre o valor biológico dos alimentos, bem como investigações fisiológicas a respeito do metabolismo basal e suas variações. Segundo ele,

O clima tropical tem sido responsabilizado por todas as más condições dos trópicos. Pelas más condições higiênicas, tendo como resultado diferentes doenças, as chamadas doenças tropicaes (febre amarela, infecções do grupo colityphico, malária, beriberi, etc.), e pela má alimentação deficiente em quantidade e qualidade. Condições sanitárias inferiores e o clima quente sempre sendo o único accusado. (Coutinho, 1937:241)

Registrava ele a existência de duas correntes de pensamento a esse respeito: os que davam ao clima todo o valor, admitindo que ele era o único responsável pelas condições de inferioridade em que viviam as populações tropicais - lassidão, fadiga, apatia, fraca resistência e avanço lento na civilização, assim como as doenças tropicais. E os outros, que julgavam que modificando as condições sanitárias e higiênicas nos trópicos, neles compreendidas as de nutrição como uma das principais, desapareceria o fantasma do clima maléfico. Dessa maneira, Coutinho (1937), em consonância com Castro (1937), assinalava que já era evidente, em 1919, pelos estudos de Almeida, que a ação mais importante dos climas quentes sobre as funções vitais do homem era o metabolismo basal como um recurso de adaptação orgânica às temperaturas elevadas. No entanto, ele foi mais longe em sua revisão teórica, discutindo a influência do clima sobre a puberdade, a etiologia da cárie dentária, a estatura, a longevidade, com vistas a demonstrar que, no Brasil, era a nutrição o fator de eficiência dos grupos sociais e não o clima e a raça.

Como Coutinho esteve voltado para a criança em idade escolar, assinalava que o abaixamento tropical do metabolismo basal, que influenciava a constituição de uma dieta para adultos, tinha pequena influência na dieta da criança. Assim, o número de calorias que uma criança necessitava por quilo era maior que o recrutado por um adulto, porque o seu metabolismo variava com a superfície do corpo e não com a massa. É certo que, em termos práticos, não havia por que adotar os esquemas de cálculo da ração energética indicados por Dubois e Lusk que incluíam, além das despesas de metabolismo basal do adulto, as despesas 
de trabalho e massa corporal. No caso da alimentação escolar, Coutinho adotava as recomendações calóricas dadas em 1923 por Sherman, professor de Columbia, para chegar ao valor energético do escolar nas faixas etárias por ele estabelecidas: o escolar de 8 a 12 anos, 2.316 calorias; de 13 a 15 anos, 2.978 calorias; e de 16 a 17 anos, 3.502 calorias.

O segundo fator a ser considerado na organização de uma dieta era a proteína, que devia perfazer $10 \%$ a $15 \%$ das calorias totais, sendo $50 \%$ de proteína de origem animal. Nas faixas etárias anteriormentte indicadas, Coutinho (1937) recomendava 2,9, 2,6 e 2,4 g de proteína por quilo de peso, respectivamente. O restante do valor calórico devia ser preenchido pelos hidratos de carbono e gorduras. No marco desta especificidade, chegava, a exemplo de Castro (1937), à normatividade das quatro convenções particulares da linguagem científica na construção do conceito de racionalidade alimentar: quantidade, qualidade, harmonia e adequação. Para ele, não importava apenas que o indivíduo recebesse a quantidade de calorias suficientes, era preciso que elas se distribuíssem em certas percentagens pelos diversos alimentos, evitando, assim, que uns fornecessem excesso de calorias em relação aos outros, às vezes de maior valor nutricional. Esse equilibrio nos fornecimentos de calorias regulava a eficiência de uma dieta.

Para isso, era necessário conhecer a composição química dos alimentos e classificá-los conforme as suas funções fisiológicas. Desse modo, Coutinho adotava a classificação proposta em 1925 por Rose, professora de nutrição do Teachers College da Universidade de Columbia, a saber: o primeiro grupo de alimentos continha apenas o leite; o segundo grupo era composto dos grãos - pão e seus derivados e cereais, fornecedores de energia, pouca proteína de segunda classe e pobres em vitaminas e minerais; o terceiro grupo era constituído pelos vegetais e frutas, fontes de vitaminas e sais minerais - substâncias reguladoras; o quarto grupo incluía os ovos, queijo, nozes, carne - alimentos fornecedores de proteína completa; o quinto grupo compreendia as gorduras - alimentos energéticos por excelência; e o sexto grupo era o dos açúcares - fornecedores apenas de energia.

Na mesma trilha de Castro (1937) e Coutinho (1937), Carmo (1937), no livro Política Alimentar Brasileira, também aprofundou a discussão sobre a influência do clima sobre o metabolismo orgânico do homem dos trópicos. Ele adotava a definição climática de Henrique Morize, segundo a qual o clima era um conjunto de fenômenos que estava na inteira dependência de inúmeros fatores, uns fixos e outros variáveis. Os fatores fixos estavam representados pelos grandes acidentes geográficos que perpassavam a grande extensão territorial brasileira. Entre os fatores variáveis de importância na individualização do clima no tempo, destacava-se o 
calor, à conta do qual se formavam os ventos, dava-se maior ou menor abundância de chuvas, produzia-se nebulosidade, processavam-se as variações de umidade e se modificava a pressão atmosférica. Para Carmo (1937:32):

O conhecimento sobre climatologia nos ensina a tirar conclusões quanto à vida dos homens que habitam tão extenso tracto de terra. Vivem os brasileiros nos trópicos, nas terras de maior valor do mundo, sob o regime de sol equatorial e tropical, onde o excesso de humidade possibilita a vida de animais e vegetaes, com toda a pujança. Os alimentos podem ser obtidos todo o ano, com um mínimo de esforço e de trabalho, visto não estar a cultura sujeita a geadas, nem à secas demasiadas, salvo o Nordeste, onde se observa, periodicamente, a estiagem.

Assim, toda a determinação científica sobre nutrição devia ter o seu ponto de partida no conhecimento do metabolismo basal que, em clima como o daqui, apresentava variantes bem apreciáveis. Na visão do autor, o metabolismo basal era a expressão do trabalho mínimo que o organismo era capaz de produzir, quando em intenso repouso de 12 horas, em jejum e equilibrio térmico. Nessas condições, tinha-se o metabolismo mínimo, o qual, dividido pela superfície corporal, determinava o metabolismo basal, considerando, para isso, as variações em função do sexo e do clima. O primeiro passo para o cálculo da ração energética requeria o conhecimento das despesas orgânicas do indivíduo (metabolismo basal, metabolismo de trabalho e metabolismo da digestão).

Para definir o metabolismo médio do homem brasileiro, Carmo (1937) procedeu a uma síntese dos três únicos estudos disponíveis, a saber: os dados fornecidos em 1919, por Almeida, em pesquisa realizada com 43 habitantes do Distrito Federal; os dados fornecidos por Castro, com a pesquisa realizada em 15 habitantes de Recife, em 1934; e os do dr. Vasco Azambuja. Com isso, ele chegava à média de 33,06 calorias de metabolismo basal, cifra aproximada do valor definido por Castro (33,8 calorias). Nisso está outro ponto de consonância com os autores anteriormente citados.

O metabolismo de trabalho era aquele desenvolvido, além do metabolismo mínimo, nos movimentos e diversos gastos energéticos. Nesse aspecto, Carmo (1937) comentava a tabela de Rubner, que dava a média aproximada de calorias por dia por quilo de peso, a saber: repouso completo, 32 calorias; trabalho corporal, 35 calorias; trabalho médio, 41 calorias; e trabalho 'considerável', 48 calorias. Nesse enfoque, outro fator merecia consideração: o metabolismo da digestão como resultante do trabalho de desenvolvimento das substâncias assimiláveis e expressão do metabolismo interno intermediário. O metabolismo da digestão era calculado em $10 \%$ sobre a soma dos dois outros. Assim, para o 
estabelecimento de uma ração normal, que fosse capaz de evitar a subalimentação e não concorresse em certas classes para a superalimentação e o desperdício, tornava-se necessário conciliar certos elementos, como: peso teórico, ${ }^{13}$ idade, sexo, função, clima onde vivia.

O segundo passo, em tal processo, era a escolha qualitativa dos alimentos e suas proporções em proteínas, hidratos de carbono, gorduras e vitaminas e minerais. Nesse enfoque, $1 \mathrm{~g}$ de proteína continha 4 calorias, $1 \mathrm{~g}$ de hidrato de carbono continha 4 calorias e $1 \mathrm{~g}$ de gordura continha 9 calorias. Assim, um plano de alimentação racional e adequada, a ser implementado pela política alimentar, deveria assentar suas bases no conceito de ração normal, que servia de eixo, por sua vez, à prescrição dos regimes nas patologias. Para Carmo (1937:83):

Entende-se como ração normal, o conjunto de alimentos que devem ser ministrados nas 24 horas para manter o equilíbrio funcional do organismo, tanto na vida de relação, como na vegetativa. Tais alimentos destinam-se a fazer face aos dispendios de energia (calor e trabalho) e de matéria (crescimento, entretenimento, reparação, etc.

Nessa visão, o equilibrio na espécie humana era obtido com um regime misto, no qual figurassem as espécies químicas fundamentais. De acordo com as regras da dietética, as proporções mínimas desses variados elementos foram indicadas por quilo de peso nas 24 horas: proteínas, 1 g; glicídios, 5 g; e lipídios, $1 \mathrm{~g}$. Postas estas regras, Carmo (1937) calculou a ração média para um homem adulto médio de 60 quilos de peso e atividade moderada com os seguintes valores: proteínas, 240 calorias; hidratos de carbono, 1.200 calorias; e gorduras, 540 calorias, perfazendo assim um total de 1.980 calorias. As indicações em gramas por quilo de peso não diferem das dos outros autores já mencionados, pois se as cifras forem transformadas em percentuais, as proporções desses três elementos básicos da ração vão-se aproximar.

No entanto, como Carmo estava voltado para a definição das linhas básicas de uma política alimentar para o Brasil, indicou, no seu livro, as recomendações do Bureau de Hygiene da Liga das Nações, destacando alguns pontos do seu relatório no que se referia às recomendações para as demais faixas etárias:

- a necessidade em calorias, nas diversas idades, era calculada sobre a base do adulto, homem ou mulher, vivendo em condições ordinárias, clima temperado e não realizando trabalho muscular profissional ou qualquer outro. A necessidade total do adulto representava 2.400 calorias;

${ }^{13}$ O peso teórico deveria ser obtido em relação à idade, sexo e altura, subtraindo na altura a constante 100. 
- pela atividade muscular deviam ser adicionados à ração de base os seguintes suplementos: trabalho muscular ligeiro - até 50 calorias/hora de trabalho; trabalho muscular médio - 50 a 100 calorias; trabalho muscular intenso 100 a 200 calorias; e trabalho muscular muito intenso - 200 e mais. Desse exercício teórico, Carmo (1937) concluía que 3 mil calorias deveriam formar a base mínima e econômica a ser aconselhada ao povo pela propaganda sanitária que ele denominava educacional.

Por mais que pareça redundante a descrição de tantos elementos de convergência, entre os autores, acredita-se que, no marco do objetivo deste estudo, torna-se fundamental marcar não somente a unicidade de uma produção compartilhada em torno dos estudos fisiológicos da alimentação, mas também destacar o encontro dos intelectuais com os mesmos interlocutores. Dessa forma, Mendonça (1938), no livro Noções Práticas de Alimentação, assinalava que o enfoque bioenergético concebia o homem como máquina em constante processo de equilíbrio energético:

A alimentação precisa levar a todos os recantos do organismo, as calorias indispensáveis à vida em constante despesa e receita. O motor comum gasta e funciona com as calorias procedentes de um único combustível - a gasolina por exemplo. O organismo, o motor humano de alta diferenciação, só funciona com calorias derivadas de diversas fontes. (Mendonça, 1938:15)

Contudo, o autor não desenvolveu nem discutiu pesquisas sobre a influência do clima sobre o metabolismo basal do brasileiro, limitando-se à indicação dos dados relativos à tabela padrão de Dubois para a determinação da ração alimentar. Isso sugere que não havia por parte do autor uma preocupação em determinar as particularidades do homem brasileiro no sentido de ajustar os parâmetros energéticos estabelecidos externamente, o que resultava na adoção de uma média padrão teórica $(39,7)$ acima da média real tal como propusera Castro (33,8 calorias).

Para Mendonça (1938), além das calorias básicas, o organismo precisava de calorias chamadas motoras para a vida de atividade ou vida de relação, essencialmente necessária ao trabalho muscular. $\mathrm{O}$ metabolismo de trabalho era proporcional aos diversos usos da força muscular. Desse modo, ele se voltava para a determinação da alimentação racional da gestante, da criança, do adulto (trabalhador leve, trabalhador braçal, desportistas e soldados) e do velho, caracterizando cada indivíduo (teórico), à luz das recomendações da Comissão Technica de Hygiene da Sociedade das Nações.

A justificação para delimitação das diversas fases da vida se dava, no nível teórico, em face da diferenciação que caracterizava a individualidade do ser humano, sobretudo no plano da alimentação. Esta variava de indivíduo para 
indivíduo conforme o hábito, a constituição, o peso, o sexo, a idade e as condições de vida. A idade adulta foi caracterizada como a segunda etapa da vida, que ia dos 20 aos 60 anos, quando se dava a maior atividade vital, no sentido do trabalho produtivo e da perpetuação da espécie. Era o período de equilibrio anabólicocatabólico, de estabilidade do corpo. Para Mendonça (1938), a percentagem dos sobreviventes nessa faixa etária sobre os nascimentos constituía o indicador do grau de riqueza e adiantamento de um povo. Nesse período da vida, o homem desenvolvia o máximo de trabalho, e por isso, a alimentação precisava proporcionar o valor nutritivo correspondente a esse trabalho. Assim, a ração alimentar racional para o adulto em trabalho leve foi determinada em 1.919 calorias, em trabalho pesado 3.885 calorias e, para o desportista, 4.854 calorias.

Seria muito extensa a descrição detalhada das recomendações feitas por Mendonça (1938) para cada faixa etária e modalidade de trabalho, pois embora ele se diferenciasse dos demais autores constituindo indivíduos teóricos, mantinhase perfeitamente articulado à perspectiva da normatividade das quatro convenções particulares da linguagem científica na construção do conceito de racionalidade alimentar: quantidade, qualidade, harmonia e adequação. Assim, o importante é destacar que o indivíduo-referência no conjunto da produção em foco era o adulto que deveria constituir o perfil biofísico do homem novo, à exceção de Coutinho (1937), que se prendeu especificamente à alimentação do escolar.

Desse modo, Mendonça (1938) também abordou o valor dos alimentos conforme a sua composição e suas funções fisiológicas, ressaltando que, dentro do hábito alimentar da civilização moderna, só se podia manter o equilíbrio nutritivo perfeito com a alimentação mista, daí a importância da ênfase na carne, no leite, nos ovos, nas verduras, legumes e frutas como alimentos essenciais ao equilibrio alimentar. O regime misto tinha outra característica fisiológica, que era a de produzir ora excesso de ácidos durante a combustão, acidificando os humores, ora excesso de valências básicas, alcalinizando o meio. Os alimentos ácidos, segundo o autor, eram as carnes, o ovo, o queijo, as gorduras, as farinhas de cereais, o pão, a aveia, o arroz, a cebola e as nozes, pela grande quantidade de ácidos que produzem durante a combustão. Os alimentos alcalinos eram as papas, leite fresco, vinho, chá, café, legumes e frutas.

Botelho (1938), no livro Os Pequenos Fundamentos da Bôa Alimentação, assinalava também que o organismo, para manter seu calor e para seus movimentos, necessitava de uma quantidade de energia que provinha da queima dos alimentos. O metabolismo mínimo era a quantidade de calor gasta pelo indivíduo em repouso completo em jejum, durante muitas horas, em temperatura agradável. Variava para cada pessoa de acordo com o sexo e a idade. Para ele, 
relacionando-se esse gasto mínimo de cada um com a sua superfície corporal, encontrado facilmente em tabelas quando conhecemos a altura e o peso, encontrarse-ia o que se chama metabolismo basal, e que seria o mesmo que relacionar o trabalho mínimo de cada motor com o seu tamanho. Desse modo, Botelho (1938) também assinalava que se julgava que o metabolismo basal fosse igual em qualquer pessoa, do mesmo sexo, idade e superfície corporal em todos os países do mundo como, no exemplo, os motores de uma mesma marca gastavam o mesmo combustivel em qualquer nação. No entanto, verificou-se que o metabolismo basal do homem brasileiro era $20 \%$ mais baixo do que o dos norte-americanos e europeus, o que seria, segundo o autor, devido ao clima. Havia uma verdadeira adaptação do organismo do homem local ao clima. Com isso, ele chegava também à primeira indicação para a quantidade de energia da ração do homem daqui. Ela deveria ser inferior à dos norte-americanos e europeus, já que seu gasto mínimo para manter o pleno funcionamento do organismo seria também mais baixo.

No entanto, o trabalho provocava um maior consumo de calor, sendo medido em calorias, que era a unidade térmica. $O$ trabalho leve exigia $35 \mathrm{cal} . /$ kg; um trabalho moderado, 45; um trabalho muito forte, 50 . Um indivíduo de peso médio, entre a população local, de $60 \mathrm{~kg}$, necessitaria de 2 mil a 3 mil calorias conforme seu trabalho fosse leve, moderado ou forte, isso tomando por base os valores indicados para o europeu ou norte-americano. No Brasil, quanto mais quente fosse a temperatura ambiente, menos energia o homem local necessitaria para reagir contra ela e manter a temperatura de seu organismo um pouco acima de $36^{\circ}$. E não só por isso necessitaria de menor valor energético em sua ração. Para esse autor, ainda havia outra razão: era que, instintivamente, para se fazer frente ao calor, executava-se as ocupações com uma certa preguiça. Era por causa dessa nossa indolência instintiva, própria a todos os habitantes de zonas quentes (egípcios, hindus), que vinha sempre a comparação irracional entre brasileiros e europeus ou norte-americanos, o que denotava antipático bairrismo, até a comparação entre os daqui mesmo, de nortistas e sulistas. Segundo Botelho (1938:17), Afrânio Peixoto resumia bem, em quatro palavras, a questão: "Calma quer dizer calor". Para ele, isso não impediu a criação, em poucos anos, da maior civilização humana dentro dos trópicos. O que era indubitável, e disso se deveria tirar proveito para a saúde e a economia local, é que precisava-se de menor quantidade de energia e tanto menor quanto se habitasse em zonas mais quentes do Brasil.

Nesse enfoque, o território brasileiro tinha, em rápida visão, duas grandes zonas: a do norte, quente, sem estações nítidas, pois a temperatura era mais ou menos uniforme durante todo o ano; $e$ a do sul, mais temperada, com estações 
mais ou menos marcadas. Assim, na zona do norte e para as estações quentes do sul deveria ser fixado o valor energético de uma ração para um homem adulto médio, em trabalho moderado, em 2.500 calorias. Para as estações frias do sul, entre 2.800 a 3 mil, para o mesmo indivíduo. Como obter essas quotas? Sem dúvida, dos alimentos. Enquanto cada grama de hidrato de carbono e de proteína se queimando dava quatro calorias respectivamente, a mesma quantidade de gordura dava nove calorias.

Dessa maneira, o segundo passo era classificar os alimentos conforme a sua composição química e suas diversas funções fisiológicas em: plásticos, energéticos (combustiveis) e reguladores. As proteínas não eram alimentos destinados à produção de calor, mas à formação do próprio organismo e à sua restauração:

Representam para o organismo, o que as pedras e tijolos representam na construção de um edifício. Cada molécula de proteico é, porém, um monte de tijolos e pedras. E assim como estes só podem ser utilisados quando isolados, um a um, assim também os protídios só podem ser assimilados quando desdobrados em substâncias muito mais simples chamadas ácidos aminados. Estes é que são os verdadeiros tijolos e pedras retirados do complexo monte que é a molécula protéica. (Botelho, 1938:20-21)

A quantidade de proteínas era fixada em relação ao peso teórico de cada pessoa, conforme o sexo, idade e altura. Por exemplo, o homem adulto, de 20 a 40 anos, necessitava de $1 \mathrm{~g}$ de proteína/kg por dia. Assim, o brasileiro de estatura média de 1,65 m de altura, entre 20 a 40 anos, com peso expresso em $60 \mathrm{~kg}$, necessitava de $60 \mathrm{~g}$ de proteínas por dia. Em que alimentos buscar estas proteínas? No leite, queijo, carnes, ovos, leguminosas e cereais. As proteínas de origem animal deveriam perfazer mais de $50 \%$ da quota da dieta. As gorduras deveriam entrar na proporção da quantidade de protídios numa relação adipoprotéica que devia ser igual à unidade. As fontes dos hidratos de carbono eram os feculentos e açucarados que provinham dos vegetais (cereais, leguminosas, raízes e tubérculos). Eram alimentos combustíveis. Queimavam-se com facilidade, tornando-se assim os mais rápidos estimulantes contra a fadiga. Assim, o adulto médio de $60 \mathrm{~kg}$ deveria receber $65 \mathrm{~g}$ de proteínas e de gorduras, que perfaziam 260 calorias das proteínas e 585 de gorduras, respectivamente, resultando num total de 845 calorias. Faltava então pouco mais de 1.600 calorias a serem preenchidas pelos hidratos de carbono para chegar às 2.500 calorias propostas como ótimas (exceto nas estações frias do sul). Com estas proporções, Botelho (1938) chegava à quota que tornava a alimentação suficiente em energia e proteína e permitia uma perfeita utilização dessas substâncias pela harmonia em que entravam na ração. A alimentação era, pois, suficiente e harmônica. 
Além disso, foram acrescidas as vitaminas (A, B1, B2, B3, C, D e E) e minerais (cálcio, fósforo e ferro), visto que eram essenciais como substâncias reguladoras e de defesa do organismo.

Tal padrão podia ser aplicado ao trabalhador empregado no comércio que exercesse moderada atividade. Os intelectuais, em movimentos muito leves, precisavam de quotas menores de hidrato de carbono, devendo dar preferência aos sais minerais e vitaminas. Já para o soldado e o marinheiro, cuja atividade era igual à do trabalhador braçal, devia ser aumentada a quota de hidrato de carbono em torno de 500 a 600 gramas. Para que um tipo de ração atingisse o 'ideal', era preciso, segundo Botelho (1938), que atendesse às condições de idade, sexo, desenvolvimento físico, gênero de vida e meio do indivíduo a que ela era destinada. No entanto, quando se organizava um tipo de ração, ele era feito para coletividades e não se podia levar em conta a constituição individual de cada um, isto é, os biotipos isolados. A ração era feita para grandes grupos. Contudo, era possível, com base no tipo de ração média, dizer alguma coisa sobre sua aplicação a indivíduos de outras idades, pois

Quando se diz que uma alimentação é racional? - A alimentação é racional quando compreende a ingestão de alimentos suficientes no quantum de energia para que cada biotipo preencha sua plena atividade social e que esses alimentos, postos em proporção harmônica para sua perfeita utilização, contenham todas as substâncias necessárias à própria vida. (Botelho, 1938:11)

Costa (1938), no livro Bases da Alimentação Racional, assinalava que, assim como o motor dos automóveis necessitava de gasolina para queimar, necessitava o corpo humano dos alimentos, como rezavam as leis da bioenergética. O fim era o mesmo: queimar para produzir calor, a fim de que a máquina humana pudesse exercer bem as suas funções. $\mathrm{O}$ alimento era, portanto, o combustível que o organismo da população local queimava para viver. Com isso, o autor tentava distinguir nutrição de alimentação. Nesse aspecto, o autor definia o metabolismo como o processo pelo qual a substância alimentar era ingerida, utilizada e eliminada com produção de calor. Para Costa (1938:30), "O equilíbrio da vida humana é o equilîbrio entre o calôr que gastamos e o calôr que recebemos dos alimentos. Trata-se de um verdadeiro orçamento. E, como nos orçamentos comerciais, é preciso que a despesa seja igual à receita para não haver prejuízo".

O autor, a exemplo de Mendonça (1938), não analisou o efeito do clima sobre o metabolismo, apenas sintetizou os princípios fisiológicos da nutrição. Coincidentemente, ele se voltava também para a definição das bases do padrão alimentar do adulto, da criança, do escolar e do idoso. Sem buscar detalhes 
sobre as variações orgânicas do metabolismo basal, ele discutiu as pequenas diferenças quantitativas entre os gastos energéticos do homem e da mulher e definia um padrão alimentar para um homem com peso de $70 \mathrm{~kg}$ chegando a um total de 2.800 calorias, distribuídas em três grandes refeições diárias, que ele considerava como um padrão médio para alimentação de adultos com atividade leve. Para os homens de atividade moderada (carpinteiros, carregadores, carteiros, copeiros), aconselhava um aumento para 3 mil calorias. Para os homens de atividade intensa (lavradores, limpadores de rua, capinadores etc.), ele aumentava para 3.500 calorias. Para os de atividade muito intensa (escavadores, rachadores de lenha, britadores, quebradores de asfalto nas cidades, trabalhadores do eito), a alimentação podia chegar, de acordo com a natureza $e$ a intensidade do trabalho, até 4 mil a 5 mil calorias por dia. Esta era, portanto, a versão quantitativa da ração alimentar racional.

Evidentemente, isso não era suficiente para explicar o fenômeno da alimentação e da nutrição, o que levou Costa (1938) à definição do alimento como substâncias que, vindas do exterior para a intimidade do organismo, iam servir eficientemente à nossa nutrição. Nesse aspecto, ele tentava distinguir nutrição de alimentação. A nutrição se efetuava na intimidade do organismo. A alimentação, essa era feita aqui fora, na sala de jantar, na saleta do almoço, na cozinha, no quintal, no recreio da escola. Só a alimentação feita de acordo com a ciência alimentar conduzia a resultados satisfatórios. Para isso precisavam ser classificados os alimentos essenciais de acordo com a composição química e suas diversas funções fisiológicas em: proteínas, hidratos de carbono, gorduras, vitaminas, sais minerais e água. As proteínas foram divididas em animal e vegetal em virtude da diferença na sua utilização biológica, sendo recomendado $1 \mathrm{~g}$ por $\mathrm{kg}$ de peso/dia para o adulto, sendo $70 \%$ de origem vegetal e $30 \%$ de origem animal. Os hidratos de carbono eram substâncias combustíveis que existiam de preferência nos alimentos de origem vegetal, que deviam perfazer $50 \%$ do valor calórico da dieta (400 a $600 \mathrm{~g}$ ). As gorduras, além de importante fonte de energia, representavam uma garantia para a continuidade das nossas trocas nutritivas, sempre que estas ficavam abaladas pela diminuição de um ou de outro princípio alimentar. É que as gorduras constituíam um material de reserva de importância incalculável. Costa calculava que $35 \%$ do valor calórico da dieta deveria ser fornecido pelas gorduras, que equivaleria a $50 \mathrm{~g}$. Assim, um grama de proteína produzia 4 calorias, um grama de hidratos de carbono produzia 4,1 calorias, e um de gordura produzia 9,3 calorias. Os minerais mais indicados foram o cálcio, o fósforo, o ferro e o iodo. Como substâncias reguladoras, as vitaminas mais indicadas foram as vitaminas B1, B2, B3, B4 e a vitamina C. 
É evidente, portanto, a aproximação de Costa (1938) com os outros autores anteriormente mencionados. Segundo ele, para ser eficiente e boa, a alimentação tinha de ser mista, e a mais variada possível. Era uma tendência natural do homem comer de tudo. A harmonia alimentar estava em garantir os alimentos em proporções adequadas do ponto de vista científico, sendo traduzida como: quantidade suficiente e presença dos mais variados alimentos nas proporções certas.

Moscoso (1939), no livro Alimentação do Trabalhador, desenvolveu também a visão do equilíbrio entre receita e despesa energética, pois isso era inerente aos fenômenos vitais que caracterizavam o plano biológico do homem em relação com uma dada unidade de trabalho. Dessa forma, o homem foi caracterizado ora como máquina ora como capital:

O homem é utensílio de trabalho ou capital, capaz de produção; esse trabalho é o preço ou o prêmio do seu valor (...). Este capital deve, pois, ser bem amparado, para garantir rendimento compensador (...) A alimentação rege-se pelos princípios de economia, não admite esbanjamento nem usura, nas trocas orgânicas qualquer das duas formas é prejudicial (...) A máquina humana não para, o seu trabalho é ininterrupto, mesmo em sossego, em repouso durante o sono, está funcionando e portanto, gastando-se e consumindo energia. É óbvio, portanto, a necessidade de compensarmos continuamente o seu uso, facultando-lhe permanente $e$ duradoura integridade, dando-lhe elementos para o suprimento e também força para o movimento, para a ação. (Moscoso, 1939:3-4)

Para ele, qualquer indivíduo, em repouso completo e em jejum absoluto durante 12 horas, despendia certo número de calorias em relação à idade e à superfície corporal (função da altura e do peso). Era o denominado metabolismo basal para o qual Dubois estipulava 39,7 calorias por hora e por metro quadrado para o homem e 37 calorias para a mulher. Desse modo, Moscoso (1939) também se referia à pesquisa apresentada por Almeida, em 1919, na qual demonstrara que o metabolismo basal entre a população daqui era inferior $20 \%$ em relação ao padrão norte-americano e europeu. Tal redução era vantajosa porque aliviava a carga de calor a ser despendida, já que o organismo tinha que lutar contra o meio externo. A exemplo dos demais autores anteriormente mencionados, este chegava à primeira indicação para a determinação das despesas energéticas do homem.

O trabalho demandava determinado número de calorias conforme a intensidade. Era o metabolismo de trabalho. A tabela de Lusk foi adotada como referência para o cálculo da adicional energética de trabalho. Desse balanço teórico, Moscoso (1939) indicava, de acordo com a recomendação da Liga das Nações, o valor de 3 mil calorias por dia para um homem de altura média cujas atividades não caracterizassem trabalho intenso nem tampouco vida sedentária. 
Voltando-se para a alimentação do trabalhador, definiu o tipo médio brasileiro, adotando as indicações estipuladas por Lobo e Silva, Roquette Pinto e Brow (altura média de $1,65 \mathrm{~cm}$ para o adulto e peso de $60 \mathrm{~kg}$, sendo a superfície corporal 1,66, de acordo com a tabela de Dubois). Dadas as características biotipológicas do trabalhador brasileiro, cumpria garantir por princípio a quantidade de alimentos necessária à cobertura das despesas energéticas de toda ordem e, com isso, assegurar os princípios nutritivos, sobretudo pela composição e uso de uma ração mista. Assim, o autor estimava em 18\% a máxima eficiência de trabalho com uma ração adequada.

Nessa perspectiva, os alimentos foram analisados em seu valor, quantidade e vantagens, formas de uso e combinações que possibilitavam aumentar o valor nutricional das refeições, com ênfase no uso da carne, do leite, dos ovos, legumes, verduras e frutas, pois

A ração deve proporcionar diariamente uma série de substâncias - energéticas - protetoras - construtoras e ativadoras. A ração só é adequada e completa quando encerra todas essas substâncias em quantidade suficiente $e$ perfeitamente equilibradas. Proteínas de diferentes qualidades estão associadas em muitos alimentos em quantidade variável, alguns são pobres, como as frutas e os legumes, outros são ricos, como o leite, os ovos, o queijo, todas as espécies de carne-gado-peixe-aves, também as leguminosas, embora em menor quota. Os cereais não tem grande porção de proteínas, mas como são consumidos em elevada quantidade tornam-se fontes de apreciável importância. (Moscoso, 1939:31-32)

Em consonância com Sherman, o autor propôs $1 \mathrm{~g}$ de proteína por quilo de peso, o que equivalia a $10 \%$ sobre o total de calorias. Os hidratos de carbono eram importantes como combustivel para a produção de calor e de trabalho muscular. Eram rapidamente queimados, transformados e transportados ao ponto de exigência de força e energia vital. A quantidade necessária era de seis a oito vezes maior que a da proteína. Quanto às gorduras, era necessário haver a relação adipoprotéica igual a um, isto é, tanta gordura quanta proteína. Os minerais foram considerados como parte da constituição dos tecidos, do estabelecimento do equilibrio físico-químico, como estimulantes dos órgãos e funções glandulares, como reguladores do ritmo cardíaco, respiratório e da digestão, destacando-se: o cálcio, o fósforo, o ferro. Como fatores acessórios, foram destacadas as vitaminas A, D, E e as vitaminas B1, B2, B3, B4, além da vitamina C. É interessante notar que todos os autores forneciam em suas obras uma lista de alimentos equivalentes.

Assim, a ração alimentar devia representar uma unidade de alimentação que, segundo a Bureau of Home Economics, comportava: 3 mil calorias, $70 \mathrm{~g}$ 
de proteína, sendo $1 / 3$ de origem animal. "Um dos principais motivos da inclusão deste modelo é realçar os alimentos imprescindíveis e insubstituíveis em uma ração adequada, além de servir de norma como ração equilibrada, adequada e suficiente". (Moscoso, 1939:77)

Chega-se finalmente, com Moscoso, a uma síntese dos pontos centrais que deram organicidade ao conjunto da produção sobre alimentação e nutrição no período de 1934 a 1939. O primeiro ponto a merecer análise diz respeito à assimilação, por parte dos intelectuais, dos princípios da bioenergética desenvolvidos a partir de Lavoisier e Laplace, como primeira indicação para a determinação do valor energético da ração alimentar racional (normal) - um atributo quantitativo. $\mathrm{O}$ segundo ponto diz respeito à necessidade de classificar os alimentos não apenas em sua composição química, mas também em suas diversas funções fisiológicas, como a segunda indicação para a determinação da ração - um atributo qualitativo, por meio do qual tornou-se possível chegar aos parâmetros de harmonia e adequação alimentar. Em síntese, por que a fisiologia se constituiu como ponto de partida para os estudos sobre alimentação, definindo o homem médio brasileiro como base da determinação da ração alimentar racional média a servir de norma para o deciframento do patológicoa fome/subalimentação?

Isso leva a considerar, de início, que a ciência é também uma produção cultural. Por meio dela os homens desenvolvem a sua própria produção, partilham uma representação do mundo. A ciência forma uma linguagem comum que fornece pontos de referência comuns a todos os praticantes. Sem essa linguagem comum é impossivel compreender a objetividade de um microscópio ou a descrição dos sistemas orgânicos.

A esse respeito, em consonância com o que orienta Le Goff (1994), é pertinente remeter a Lavoisier e Laplace, bem como a Quetelêt, para a análise dos pontos anteriormente levantados, de modo a situar os elementos de rupturas e continuidades operados pelos intelectuais ao elegerem a fisiologia como ponto de partida para os estudos sobre alimentação e nutrição.

Partindo dessa premissa, a reflexão passa inicialmente pela química, que foi proeminentemente uma ciência francesa. Seu verdadeiro fundador, Lavoisier (1743-1794), publicou o fundamental Tratado Elementar de Química no próprio ano da revolução. No entanto, foi no século XIX que a química deu um salto revolucionário: Lavoisier descobriu que a respiração era uma forma de combustão, estabelecendo a relação entre a produção de calor e utilização de oxigênio do organismo (Hobsbawn, 1981). Com isso surgia o período físicoquímico da nutrição humana. 
Os princípios da bioenergética de Lavoisier traziam embutido o postulado de que os seres vivos estavam sujeitos às leis gerais da natureza e que suas manifestações eram expressões físico-químicas. Laplace foi colaborador de Lavoisier nas pesquisas sobre a respiração e sobre o calor animal, primeiro êxito das pesquisas sobre os fenômenos biológicos, no momento em que os métodos de experimentação e da medida eram creditados em física e em química. Como adepto da fisiologia, Laplace desenvolvia a visão determinista que tinha como conseqüência a redução da qualidade à quantidade que está aplicada na identidade essencial do normal e do patológico. Nesta visão, o estado fisiológico era concebido como um simples resumo de quantidades, simples sistemas de fatos físicos e químicos e, assim, esse estado não tinha qualquer qualidade vital e não se podia chamá-lo de são, nem de normal, nem de fisiológico (Canguilhem, 1990).

Para Landmann (1984), nisso estavam postos dois princípios universais do corpo: a matéria e o movimento. René Descartes, no início do século XVII, estendeu a mesma interpretação mecânica criada do mundo físico (por Galileu) aos seres vivos. Segundo Rossi (1989), Descartes concebeu o corpo humano como máquina, governada pelas leis da física, que podia ser montada, desmontada e reconstruída se as suas partes fossem compreendidas. A adoção do modelo máquina à explicação integral da realidade física e biológica em termos de matéria e movimento comportava, assim, uma modificação do conceito de natureza. Ela não aparecia mais composta por formas e essências com qualidades inerentes, mas por fenômenos quantitativamente mensuráveis.

Ancoradas nesse postulado, a fisiologia experimental, a patologia e as pesquisas biométricas em fisiologia, como instâncias definidoras do normal e do patológico, sofreram acentuadas críticas no início do século XX quanto ao caráter determinista que projetavam em relação à doença, à cura e à saúde.

No campo das pesquisas biométricas, Canguilhem (1990) destaca as críticas de Maurice Halbwachs, em 1912, às idéias de Quetelêt. ${ }^{14}$ Para ele, o

\footnotetext{
${ }^{14}$ Foi Quetelêt que, na Bélgica, iniciou o movimento biométrico. Ao estudar em 1843 as variações da estatura do homem, ele constatou a existência de um polígono de freqüência que apresentava um máximo correspondente à ordenada máxima e uma simetria em relação a essa ordenada. Esse polígono de freqüência tendia para uma curva em sino semelhante à curva binomial de Gauss. A distribuição dos resultados de medida aquém e além do valor médio garantia que a média gaussiana era uma média verdadeira. Dentre um grande número de homens cuja estatura variava dentro de limites determinados, aqueles que mais se aproximavam da estatura média eram os mais numerosos. A esse tipo humano Quetelêt deu o nome de homem médio. Isso levava ao reconhecimento de que não havia na variação individual referente à estatura nenhum outro sentido a não ser o de um acidente que confirmava as leis do acaso, em que os efeitos de uma multiplicidade de causas não sistematicamente orientadas tendiam a se anular por compensação (CANGUILHEM, 1990).
} 
interesse que a concepção de Quetelêt apresentava consistia no fato de identificar, em sua noção de média verdadeira, as noções de freqüência estatística e de norma, pois uma média que determinava desvios, tanto mais raros quanto mais amplos fossem, era uma norma. No entanto, Quetelêt, de modo algum, apresentava a média como fundamento empírico da norma, em matéria de caracteres físicos humanos. Ao contrário, ele explicitava a regularidade ontológica como algo que se expressava na média, e era nisso que residiam as críticas a ele dirigidas por Halbwachs (Canguilhem, 1990).

Realmente, a crítica fundamental em torno da visão de Quetelêt estava no fato de que ele não tinha razão quando considerava a distribuição da estatura humana em torno de uma média como um fenômeno ao qual se pudesse aplicar as leis do acaso, pois não se podiam identificar efeitos orgânicos constantes regidos pelas leis do acaso. O determinismo estava em admitir que os fatos físicos que dependiam do meio e os fatos fisiológicos inerentes aos processos de crescimento se entrecruzavam de modo independente um do outro na constância desse processo. No entanto, na espécie humana a estatura era um fenômeno inseparavelmente biológico e social. Mas, se era verdade supor que o corpo humano era, em certo sentido, produto da atividade social, não era absurdo supor que a constância de certos traços, revelados por uma média, dependesse da fidelidade consciente ou inconsciente de certas normas de vida. Desse modo, na espécie humana, a freqüência estatística não traduzia apenas uma normatividade vital, mas também uma normatividade social (Canguilhem, 1990).

É por essa ótica que se pode entender o uso da fisiologia como ponto de partida para os estudos sobre alimentação no período de 1934 a 1939. Os intelectuais, ao adotarem compartilhadamente as expressões 'corpo-máquina' e 'alimento combustivel', preservavam de fato os postulados da bioenergética desenvolvidos por Lavoisier e Laplace, bem como a biometria de Quetelêt, submetendo-os, porém, a um processo de reinterpretação, em que o homem brasileiro passava a ser concebido como capital, porque era capaz de produzir, sendo o trabalho o prêmio do seu valor, na expressão de Moscoso (1939). Como capital, esse homem precisava ser qualificado em sua resistência física e robustez por uma alimentação cientificamente racional que assegurasse rendimento compensador. Assim, o alimento não mais podia ser concebido como combustível porque as suas funções não se reduziam a esta dimensão fisico-química, mas em suas qualidades fisiológicas como construtores, reparadores e reguladores dos diversos órgãos vitais no adequado funcionamento orgânico. Era por essa ótica que o alimento passava a ser concebido como elemento de interação entre 
o homem e o meio, não obstante a diferença entre os intelectuais na elaboração de uma concepção biossociológica de alimento, como será visto no transcorrer deste trabalho.

Assim, aproximando-se de Bennedict, Lusk, Dubois e Almeida, entre outros, para a determinação do metabolismo basal do brasileiro, eles se alinhavam a pesquisadores que estudavam o metabolismo basal em suas relações com o clima e a raça e davam os primeiros passos em direção a uma fisiologia comparada que marcaria a ruptura com o determinismo do conceito de bioenergética e de biometria. Bennedict, por exemplo, constatava que não mudou o metabolismo basal dos americanos do norte que se deslocaram para as regióes subtropicais. Porém, constatou que o metabolismo das chinesas que sempre viveram nos Estados Unidos era mais baixo que a norma americana. Disso era possível supor que o fator climático não exercia efeito direto sobre o metabolismo, e que só progressivamente modificando o modo de vida, o clima tinha uma ação durável sobre o metabolismo basal (Canguilhem, 1990).

Assim, só a fisiologia comparada possibilitava uma experimentação que estabelecesse comparações entre grupos e subgrupos humanos, levando em conta a complexidade da vida, dos gêneros de vida e dos níveis de vida. Era nessa perspectiva que fazia sentido o uso da fisiologia nos estudos sobre a alimentação brasileira. Na medida em que não se afirmava nos laboratórios, a fisiologia não apenas permitia estabelecer previamente uma normatividade vital (o metabolismo basal médio, o homem médio e a ração alimentar média) e seus verdadeiros limites de variação, mas também, aproximando-se da geografia humana de La Blache (1936), assegurava as condições para o conhecimento de uma ecologia do homem, como afirmava Castro (1935:48): "Estudar o trabalho agrícola, analisar a paisagem cultural, sem conhecer a paisagem natural é querer estudar aritmética sem estudar os números".

Com isso, depreende-se que a forma e as funções do corpo humano não podiam ser traduzidas apenas enquanto expressão de condições impostas pelo meio, mas a expressão de um modo de vida socialmente determinado pelo meio, - que remetia necessariamente à multiplicidade das interações entre natureza e cultura na fixação das normas orgânicas. Assinala Canguilhem (1990:126) que: "Um traço humano não seria normal por ser freqüente, mas seria freqüente por ser normal, isto é, normativo, num determinado 'gênero de vida'... ( ) no sentido que lhes foi dado pelos geógrafos da escola de Vidal de La Blache". De fato, os "gêneros de vida' de La Blache traduziam a possibilidade de invenção de técnicas coletivas que definiam, em certa medida, a normatividade vital do homem num dado meio geográfico e social. 
Portanto, a definição do metabolismo basal médio do homem brasileiro, sob a influência do clima, indicava a existência de uma constância fisiológica normal como produto de uma normalização entre funções e órgãos cuja harmonia (aclimatação) não era oferecida gratuitamente e sim conseguida em condições definidas. As condições brasileiras asseguravam uma instância demográfica em que a uniformidade das características humanas traduzia não a inércia de um determinismo geográfico (lassidão, fadiga, indolência), mas a estabilidade de uma particularidade fisiológica construída por um esforço coletivo real.

Disso parece ficar claro, também, que o uso da categoria trabalho como dado fundamental nos estudos fisiológicos para a definição das despesas energéticas do homem brasileiro não pode ser traduzido apenas como uma medida de redução desse homem às leis quantitativas da bioenergética em que o corpo era concebido como uma máquina, governada pelas leis da físico-química, que poderia ser montada, desmontada e reconstruída se as suas partes e funções fossem compreendidas. O que distinguia os estudos fisiológicos da alimentação no período de 1934 a 1939, da fase físico-química, era exatamente a perspectiva de reposição ao homem da qualidade negada, não no sentido de substituir o componente quantitativo pelo qualitativo, e sim de aproximar os pólos de oposição, como será visto.

Nesse aspecto, a definição da estatura do homem médio brasileiro (1,65 m) como base para a determinação da ração alimentar racional média se afastava também da biometria de Quetelêt, na medida em que se assentava nos princípios da fisiologia comparada pelos quais a estatura devia ser concebida como um fenômeno simultaneamente biológico e social. Significa dizer que os estudos sobre alimentação, assim concebidos, tinham um alcance diferente dos postulados deterministas-normativos da fisiologia restrita ao âmbito do laboratório, bem como da biometria.

No Brasil, um dos adeptos da biometria foi Roquette Pinto, cuja obra Ensaios de Antropologia Brasiliana foi publicada em 1933. Neste livro, o autor dimensionava a constituição física e a capacidade vital dos brasileiros, tomando por base de estudo cerca de duas mil fichas obtidas com rapazes de todos os estados, filhos e netos de brasileiros, de $20 \mathrm{a} 22$ anos, todos sadios e sujeitos às mesmas condições de vida. Em vez de fazer uso das fichas e determinar as diferentes médias aritméticas, ele preferiu fazer a análise dos tipos, realizando a 'seriação dos caracteres', de acordo com a sua freqüência, conforme se praticava em toda a biologia. Entre os quatro tipos principais, vale destacar os Leucodermos (brancos): altura ao redor de 1,63 m e 1,69 m, dentre os quais se achavam os mais numerosos entre os tipos acima da média geral (1,65 m). Com isso, o autor 
afirmava que o mestiço não era fisicamente nem moralmente degenerado, devendo ser educado e não substituído. ${ }^{15}$ Foi exatamente a média de $1,65 \mathrm{~m}$ de altura que os intelectuais em sua maioria adotaram como base do cálculo da ração alimentar racional média do homem brasileiro, visto que Roquette Pinto se constituiu em interlocutor privilegiado no conjunto da produção sobre alimentação.

Portanto, a qualidade vital era reposta ao homem, não apenas pelo cálculo das despesas energéticas do organismo, cuja fonte de receita era o alimento reduzido à sua dimensão química quantitativa, mas também pelo conhecimento da interação dos nutrientes dos alimentos e suas diversas funções fisiológicas, de cujo caráter qualitativo era possível chegar à definição de harmonia alimentar e adequação, como pré-requisitos do equilibrio vital e da robustez. Dessa forma, Carmo (1937:41), por exemplo, reiterava a definição de Pende, segundo a qual "o homem normal será aquele que reunir todos os atributos anatômicos, funcionais e psíquicos, tomados separadamente, mas formando um complexo harmonioso". $\mathrm{O}$ que produziu o conceito de racionalidade alimentar foi a definição da normatividade de quatro convenções particulares da linguagem científica quantidade, qualidade, harmonia e adequação-, as quais constituíram, finalmente, a dietética como núcleo instrumental fundamental (ancorada na fisiologia) por meio da qual seria decifrado o fenômeno patológico - a fome/subalimentação. Como assinalava Carmo (1937:88), "o ideal da dietética é reconduzir, o mais rápido possível, ao regime misto que é o normal". A quantidade foi definida pela suficiência calórica da ração racional para repor as perdas energéticas do organismo. A qualidade foi definida pela variabilidade de alimentos, e o seu teor de nutrientes, o que permitia operar com esquemas de substituição e equivalência. A harmonia foi definida pela proporcionalidade entre os nutrientes e o valor calórico total e, finalmente, a adequação foi definida pelo respeito à individualidade.

Em última instância, a fusão da fisiologia comparada com o método geográfico de La Blache estava na mira da arquitetura de um método único, pelo qual a educação alimentar ia-se configurando. Dessa maneira, a descontinuidade operada pelo novo paradigma a ser proposto estava na ruptura com a ciência de Galton (1875) e a antropologia física (1859) que, ao estender e aperfeiçoar o método de Quetelêt, e a doutrina racial de Goubineau, sustentavam as teses deterministas de meio e de raça que adquiriram expressão no Brasil da Velha República.

Coincidentemente, para Gesteira (1945), o aperfeiçoamento racial, conforme preconizava a ciência de Galton, dependia de uma seleção conjugal

${ }^{15}$ Ver RoQuetTe Pinto (1982). 
efetuada com critério, com método, idéia essa que devia ser incutida com intensidade quase religiosa no cérebro de todos os indivíduos e no espírito da opinião pública. No entanto, o autor, como idealizador da puericultura ${ }^{16} e$ catedrático da cadeira de puericultura e clínica da primeira infância da Faculdade Nacional de Medicina, advogava a eugenética de Pinard, por ser menos ousada e mais modesta e prática nos seus meios de ação do que a eugenia de Galton, cujo escopo era elevado demais para o puericultor. Na visão de Gesteira (1945), a puericultura era a parte principal da eugenia, não no sentido da sua universalidade - o da seleção da raça e do seu aperfeiçoamento. Ao contrário, ela tinha como proposição um plano de higiene alimentar e de educação das mães. Era, portanto, nas fronteiras desses campos que se iam delineando o objeto e o método definidor da ciência da nutrição no período de 1934 a 1939.

Fome e subalimentação: a norma é não ter regime algum entre pobres e ricos

A aproximação da fisiologia comparada com o método geográfico de La Blache, no percurso de caracterização inicial do objeto da educação alimentar, forneceu aos intelectuais os elementos para a configuração de uma espécie de biogeografia da situação alimentar brasileira em que a fome e a subalimentação foram decifradas em suas diversas formas de expressão. Dessa forma, é digna de nota a diversidade de terminologias utilizadas pelos explicadores da situação alimentar, no período de 1934 a 1939, momento em que o objeto ainda não apresentava contornos nítidos e precisos e o método explicativo adquiria uma arquitetura particular.

La Blache (1936) assinalava que a geografia humana era um dos ramos que havia nascido recentemente do velho tronco da geografia. Para a maior parte dos autores da antiga geografia, a idéia de região era separada de seus habitantes, e o exotismo se traduzia menos pelos meios de alimentação e aspecto físico dos homens do que pelas montanhas, desertos e rios que os rodeavam. A geografia humana se opunha a esta geografia descritiva da qual o homem era excluído. Nesse aspecto, a geografia humana aportava uma concepção nova e explicativa das relações entre a terra e o homem, concepção gerada por um . conhecimento das leis físicas que regiam nossa esfera terrestre e das relações entre os seres viventes que a povoavam.

\footnotetext{
${ }^{16}$ A cadeira de puericultura e clínica da primeira infância foi criada na Faculdade de Medicina da Universidade do Brasil em 1937 pela Lei n² 586, de 9 de novembro desse ano. (Ver Brasil, 1938).
} 
Nessa perspectiva, para analisar as relações entre a terra e o homem, a primeira questão que se colocava dizia respeito ao modo como a espécie humana estava distribuída na superfície terrestre, à delimitação dos espaços geográficos (regiões), à densidade demográfica e às características dos agrupamentos humanos, os movimentos migratórios. Desse modo, a ênfase recaía inicialmente nos modos de ocupação dos espaços. O segundo ponto no conhecimento das relações entre a terra e o homem estava na caracterização e análise das suas diversas formas de civilização, as formas de adaptação ao meio, os instrumentos e os materiais coletivamente construídos, os meios de nutrição e as características das práticas alimentares dos diversos grupos humanos, os materiais de construção e as características dos diversos tipos de habitação, elementos resultantes do processo de evolução das civilizações em que se davam fenômenos de estagnação $e$ isolamentos, de contatos por invasão e oposição de gêneros de vida e pelo desenvolvimento do comércio marítimo. Nisso residia a explicação das características regionais do progresso civilizatório pelo qual se delineavam os diversos gêneros de vida. Ganhava expressão na relação entre o homem e a terra o fenômeno da circulação, com os seus diversos meios de locomoção terrestres e marítimos e, finalmente, a configuração das raças e os meios de difusão das invenções. Havia, para La Blache (1936), uma relação entre os diversos gêneros de vida e o avanço da civilização, que culminava, enfim, com o surgimento das cidades como uma organização social de maior envergadura. Elas representavam um estágio de civilização que muitas regiões não atingiriam jamais.

Tais postulados e categorias analíticas perpassaram em grande medida o estudo de Castro (1937), no livro A Alimentação Brasileira à Luz da Geografia Humana, a partir da argumentação de que, uma vez fixadas as bases fisiológicas da ração alimentar racional (normal), era possível fixar os hábitos alimentares do povo, apurando, estatisticamente, a composição dos regimes alimentares e destacando os erros capazes de influenciar na evolução social. "Assim, partindo da fisiologia, ciência teórico-especulativa, chegamos à higiene, ciência práticaaplicada, em cujas soluções trabalham simultaneamente os princípios científicos de várias disciplinas básicas" (Castro, 1937:28).

Nesse enfoque, a fome e a subalimentação foram decifradas como duas modalidades de expressão da alimentação coletiva, trazendo à tona, no cenário brasileiro desse tempo histórico (1934 a 1939), que a norma era não ter regime algum entre pobres e ricos. Em verdade, a tendência explicativa que aplicou o método geográfico não se orientou pelo uso de um único meio de abordagem da alimentação coletiva, mas o inquérito alimentar já ia adquirindo forma e 
expressão como instrumento de investigação, ao mesmo tempo em que se iam constituindo os parâmetros de normatividade da alimentação racional.

De fato, Castro (1937) reconhecia a existência de documentos históricos, acentuando os defeitos da alimentação brasileira, mas eles eram cientificamente imprecisos, dado que traduziam mais a sensação de quem se alimentava mal, sem apontar onde estavam os defeitos, ressentindo-se, assim, de um pensamento lógico sobre o porquê de a alimentação ser deficiente. Considerando os resultados do rastreamento da produção sobre alimentação e nutrição, no âmbito do período em foco, os inquéritos alimentares tomaram impulso como instrumento sistematizado de investigação, com a publicação de Castro (1935), As Condições de Vida das Classes Operárias no Recife. O inquérito realizado pelo autor sobre as condições de vida de 500 famílias de classes operárias de Recife, por intermédio da Diretoria de Saúde Pública de Pernambuco, foi exaustivamente comentado em seu livro Alimentação e Raça (1936). O estudo da distribuição das populações em classes sociais e profissões, feitos à luz da demografia, era de capital importância para a avaliação da capacidade econômica de um povo; porém, as indicações obtidas ainda seriam mais úteis e precisas se fossem cotejados os dados estatísticos e econômicos de índole puramente social com os dados de indagação biológica das classes sociais. Um dado importante nesta perspectiva era o de que não bastava saber a quantidade de homens que produziam, mas também a sua qualidade. Assim, o inquérito visava verificar o padrão de vida das classes operárias da cidade do Recife, estabelecendo os valores médios dos salários e dos custos de sua subsistência, isto é, a distribuição proporcional dos seus gastos e, particularmente, aqueles referentes à alimentação e à sua composição média habitual.

Nesse enfoque, como as antigas aristocracias e o feudalismo impunham a existência de servos e escravos, o regime capitalista da época implicava a existência de assalariados, encarregados dos trabalhos manuais em todos os países. Na Europa, o proletariado apareceu e desenvolveu-se ao lado das classes burguesas. No Brasil, com a abolição da escravidão, novos elementos vieram se incorporar a essa classe, que, nos centros urbanos, com a industrialização progressiva daqueles dias, constituía o grosso da população (Castro, 1936).

Em verdade, foi na trajetória de ascensão da República Velha que ocorreram mudanças significativas na estrutura e na composição social brasileiras. A instituição da divisão do trabalho, em conseqüência do desenvolvimento das forças produtivas, acarretou mudanças das velhas camadas sociais e o aparecimento de novas camadas. A estratificação social representada pelo predomínio do senhor/escravo foi-se diluindo com o aparecimento de outros 
grupos socioeconômicos mais complexos. Da dinâmica agrária, surgiram o capital industrial e os demais fatores favoráveis e desfavoráveis ao surgimento e desenvolvimento da indústria. Do oeste paulista, por exemplo, saiu a maior parte de capitais para a industrialização de São Paulo. O desenvolvimento desigual da produção agrária de exportação nas regiões brasileiras promoveu, nos momentos de crise, o deslocamento de parte das oligarquias agrárias para as cidades, assim como grande parte dos trabalhadores livres que já sofriam crescente processo de marginalização, após a abolição da escravatura, pela política de incentivo à imigração externa. Assim, a indústria se tornou realidade nas primeiras décadas do século XX, sob a liderança de Jorge Street, industrial que liderou o Centro Industrial do Brasil, centrando-se na reivindicação de direitos e rebatendo críticas das oligarquias agrárias, que acusavam os industriais de obterem lucros exorbitantes e de serem responsáveis pelo aumento do custo de vida (Carone, 1975a; Carone, 1975b; Carone, 1977).

No âmbito desse dinamismo, Carone (1975a) e Fausto (1976) descrevem e analisam o surgimento, a composição, as formas de organização, os interesses, os conflitos e as reivindicações das diversas classes sociais brasileiras em formação e, com isso, assinalam campos bastante divergentes de visão de mundo e de sociedade: oligarquias agrárias, burguesia, classes médias (alta, média e baixa, com formação diversa) e classes operárias. A classe média, por exemplo, encontrava explicação para o problema do aumento do custo de vida e da escassez de alimentos na simples ganância de especuladores, que podia ser debelada por uma ação enérgica do Estado, ao passo que, para a classe operária, a questão da especulação era mais complexa e estava ligada à estrutura socioeconômica.

Em meio a essa transição, Castro visualizava a existência do desequilíbrio alimentar das classes operárias, caracterizado por um regime insuficiente, incompleto e desarmônico. Era insuficiente, por não ter o total de calorias necessárias; incompleto, por seu déficit de proteínas, cálcio e ferro e, além disso, era deficiente em vitaminas, dado o baixo uso de legumes, verduras e frutas; era desarmônico porque continha um excesso de hidrato de carbono em proporção às gorduras e ainda em proporção aos demais elementos de utilização nutritiva. Segundo o autor, o regime médio habitual da totalidade das famílias estudadas era equivalente a 1.645 calorias, quando um trabalhador necessitava, em média, de 3 mil a 4 mil calorias para suas necessidades fundamentais de trabalho. Em $100 \%$ das famílias, tal regime era composto de feijão, farinha, charque, café e açúcar, sendo o pão utilizado por $80 \%$ das famílias. Os demais alimentos (carne verde, milho, arroz, leite e derivados, verduras, frutas, gorduras) eram consumidos 
por pequeno número de famílias; contudo, as famílias gastavam, em média, $71,6 \%$ dos seus salários com a alimentação, enquanto $9,6 \%$ das despesas eram com habitação, 9,3\% com água e luz, e 9,3\% com outras, quando os estudos oficiais procedidos nos Estados Unidos estabeleceram que o operário de salário mínimo devia despender $55 \%$ em sua alimentação. Estatísticas argentinas, publicadas pelo Departamento Nacional do Trabalho, indicavam para o operário de Buenos Aires uma quota alimentar de 52,7\%. Donde Castro deduzia ser entre os brasileiros esta porcentagem de $71,6 \%$ excessivamente elevada, demonstrando que os salários daqui estavam muito abaixo do mínimo. Assim,

Diante desta exposição fica evidenciada a péssima qualidade da alimentação operária, sendo seu regime impróprio sob todos os aspectos. Só há uma maneira de alimentar-se peor do que esta; é não comer nada. É por isto, que esta gente não fala em alimentar-se, mas enganar a fome. Infelizmente a fome não se deixa enganar, apenas ilude-se sua sensação consciente, mas na intimidade profunda de cada célula perduram indefinidamente os seus efeitos. (Castro, 1936:104)

Com isso, o autor queria dizer que não se afirmava a dimensão socioeconômica e cultural da alimentação negando o biológico, pois, nesse nível, as leis também eram rigorosas, adaptando-se às leis sociais até certo limite, que, uma vez ultrapassado, o organismo lançava mão do último recurso: a doença e a morte. É evidente que, nesta conexão biossocial, a teoria do contágio perdia força explicativa. O coeficiente de mortalidade em Recife $(27,9)$ era mais elevado do que em São Paulo (15,3), Rio de Janeiro (18,8), México (17,1), Paris (14,5), Londres $(11,8)$ e Nova York $(17,1)$, quando $18 \%$ dessa mortalidade geral tinha como causa mortis a tuberculose que, segundo Escudero, era uma doença da nutrição (Castro, 1936). O coeficiente de mortalidade infantil de Recife atestava também um índice eloqüente da deficiência nutricional. Portanto,

Maior importância que o contágio tem o terreno, na etiopatogenia da tuberculose, e a melhor maneira de tornar êsse terreno predisposto é alimentar mal o organismo. A tuberculose é uma das maneiras disfarçadas de se morrer de fome; fica-se tuberculoso procurando fugir à fome, alimentando-se de si mesmo (...) verificamos que $58 \%$ dos óbitos se dão antes dos 30 anos, antes da maturidade, que é o período da vida de maior rendimento e portanto de mais alto valor do capital humano. (Castro, 1936:105-106)

Vale ressaltar que o ano de 1935 já configurava uma nova etapa na vida social econômica e cultural brasileira, na medida em que, a partir de 1930, o Estado se reorganizava e incluía em sua agenda a questão social das massas trabalhadoras urbanas, redefinindo as relações de trabalho e definindo um novo tipo de relações entre o Estado e a classe operária; instituindo a carteira de 
trabalho, em 1932 (Brasil. Leis e Decretos, 1933); criando o Departamento Nacional do Trabalho, em 1934 (Brasil. Leis e Decretos, 1936); e vinculando os sindicatos ao Ministério do Trabalho, em 1934. Muitos dos direitos acenados para o operariado e os trabalhadores do comércio só seriam cumpridos, de fato, tempos depois da sua criação, como o do salário mínimo que, embora tivesse sido finalmente assegurado com a Constituição de 1937, só foi instituído em 1940. No elenco de direitos estavam: a jornada de trabalho de oito horas, férias remuneradas, estabilidade no emprego, indenização por dispensa sem justa causa, convenção coletiva de trabalho, a regulamentação do trabalho das mulheres e de menores, assim como os Institutos de Aposentadorias e Pensões, que garantiam assistência àqueles grupos.

O Estado, ao instituir novas relações de trabalho no interior das reformas econômicas, substituía, por um lado, o modelo anacrônico das relações sedimentadas na República Velha, onde a questão social era colocada como questão de polícia, e, por outro, reconhecia a existência das massas operárias, ao tempo em que visava ao seu disciplinamento e controle político por instrumentos de representação profissional dos sindicatos oficiais, apolíticos, como fica caracterizado na lei (Brasil. Leis e Decretos, 1936).

No entanto, a caracterização da dinâmica específica da acumulação do capital, embora constitua a chave explicativa no processo de desnudamento das transformações vivenciadas pela sociedade brasileira, no período em foco, não esclarece por si só o conteúdo cultural das relações sociais estabelecidas nesse processo. Assim, o que está em evidência é que, no plano cultural, o ano de 1935 foi um marco na incorporação de um novo conceito de medicina social, pelo qual as massas trabalhadoras passaram a ser reconhecidas pelo Estado em sua substância corpórea e mental, sendo a alimentação o substrato fundamental potencializador da sua vitalidade. A medicina social compreendia um conjunto de práticas que incluíam vários domínios do conhecimento (a higiene, a clínica, a sociologia, a pedagogia etc.), visto que não bastava curar, havia todo um enfoque sanitário que buscava a proteção do corpo e da mente do trabalhador. Vinculavam-se estreitamente as legislações social e sanitária, na perspectiva da construção de um trabalhador forte e sadio com capacidade produtiva ampliada.

Foi nesse contexto que Castro (1937) ampliou, no livro A Alimentação Brasileira à Luz da Geografia Humana, o debate sobre a situação alimentar da classe operária urbana, configurando o método geográfico como guia orientador de um objetivo prático: o estudo higiênico do problema. Confrontando os resultados do inquérito que realizou em Recife (1935) com os de São Paulo, 
apresentados nesse mesmo ano por Paula Souza, Horaces Davis e Almeida Júnior, Castro concluía que a alimentação, tanto do Norte como de São Paulo, era sempre inadequada, mesmo em classes de boa situação econômica, como indicava o inquérito de Almeida Júnior com famílias de professores, médicos, funcionários públicos e pequenos comerciantes. Isso levava o mencionado autor à dedução de que em todo o Brasil a alimentação era falha, cuja premissa causal imediata era o salário reduzido. Se, por um lado, os trabalhadores de São Paulo, mesmo em circunstâncias de razoável abundância de empregos, não se encontravam em condições satisfatórias de habitação e vestuário, por outro, apesar dos baixos preços dos alimentos, despendiam com gêneros uma proporção da sua renda maior que a considerada normal entre os operários dos países de civilização mais antiga.

É verdade que ele não indicava ainda uma terminologia clara na caracterização do desequilíbrio alimentar, mas chegava à constatação da existência de duas modalidades de defeitos que, no nível do consumo, podem ser traduzidas nos termos fome e subalimentação: em algumas regiões brasileiras, as falhas da alimentação eram de ordem quantitativa global (fome), como no Nordeste, tendo como causa básica o modo de organização econômico-social em que se afirmava a monocultura da cana-de-açúcar, que arrastava as populações desta região à miséria. Nas regiões mais favorecidas, as falhas residiam nos déficits qualitativos (parciais), caracterizando o estado de subalimentação qualitativa. Com isso, Castro queria frisar que

esta alimentação tem pesado dolorosamente na economia da nação, paralizando, roubando mesmo, a maior parte do seu capital humano, provocando discretamente a maior parte dos obstáculos que aparecem como obra do clima. Clima que permitiria, pela riqueza de produtos cultiváveis entre nós, pelo aproveitamento racional das nossas reservas naturais de nutrição, uma alimentação bem melhor, bem mais equilibrada. (Castro, 1937:133)

Com efeito, iam-se configurando, no período de 1934 a 1939, os contornos de uma normatividade social, na relação homem/alimento, que demandava a definição de uma nova racionalidade no cenário cultural. Como será visto, vaise apresentando no conjunto da produção em foco a constatação de que, se os pobres se alimentavam mal por falta de dinheiro, pobres e ricos comiam mal por ignorância completa do que era comer bem. Para Castro (1937), os erros habituais do modo brasileiro de se alimentar tinham suas raízes no processo de organização econômico-social do País, a partir do momento em que o colonizador português perdia as características da sua boa tradição alimentar ao chegar às terras virgens da América. As condições do meio começavam por impossibilitar a cultura do 
trigo, base quantitativa da sua alimentação, deslocando-a para a farinha de mandioca, de cultura ameríndia, alimento muito mais pobre e incompleto do que o trigo, com proteína de mais baixo valor biológico, quase sem vitaminas e de baixo coeficiente de digestibilidade. Disso resultava o rebaixamento da produção alimentar do Brasil.

O novo momento trazia à tona a exigüidade da base econômica em que se assentava a vida brasileira. Tornara-se patente a incompatibilidade substancial entre o novo ritmo de existência e progresso material atingido pelo País e sua modesta categoria de mero produtor de um punhado de matérias-primas destinadas ao comércio internacional. O problema consistia em sustentar o ritmo do desenvolvimento adquirido com a produção de uns poucos gêneros que, embora de grande expressão comercial, mostravam-se insuficientes para a função que deles se exigia. Apresentava-se, então, a perspectiva de estagnação e decadência. Disso resultavam as primeiras iniciativas de uma economia nacional, voltada para o País e para as necessidades próprias da população; uma organização destinada a mobilizar e coordenar os recursos e o trabalho em função precípua dos indivíduos e da comunidade nela enquadrados e não a servir antes a interesses estranhos (Prado Júnior, 1978).

O progresso dessa nova economia em germinação era condicionado sobretudo pela constituição e ampliação de um mercado interno, isto é, o desenvolvimento do fator consumo, pouco significativo no conjunto do sistema anterior, em que prevalecia o elemento produção. Aos poucos, a produção interna, tanto agropecuária como industrial, poderia ir fazendo frente, em proporções cada vez maiores, às solicitações de consumo. Apesar do crescimento da população, a tendência era para o declínio e mesmo desaparecimento da importação de vários itens que nela ocupavam posição de destaque; assim ocorria com os gêneros alimentares e com grande número de manufaturas, sobretudo de bens de consumo. Na agricultura se assistia a uma diversificação progressiva de atividades e, a par dos poucos gêneros exportáveis que dantes representavam a massa da produção brasileira, aparece toda uma gama de artigos de consumo interno. $\mathrm{O}$ consumo de cereais (exceto o trigo), de hortaliças, de derivados animais (leite, manteiga, ovos), de vinhos e frutas de mesa européias, gêneros esses adquiridos, em sua maior parte, em princípios do século XX, no estrangeiro, tornava-se, na sua quase totalidade, atendido pela produção nacional. Tal desenvolvimento vinha acompanhado de transformações estruturais, entre as quais se destacava o grande crescimento da população urbana em virtude do progresso industrial, que se constituía de núcleos de elevado nível econômico e grande potencial de consumo, bem como a remodelação, ainda que modesta, do aparelhamento 
comercial e de distribuição que se ia adaptando às novas contingências de um grande mercado interno. Foi, portanto, depois de 1930 que todo esse processo de transformação se acentuou (Prado Júnior, 1978).

No âmbito das reformas estruturais e da saúde pública, os inquéritos alimentares se constituíam em instrumentos de investigação do complexo ambiente cultural - o homem e o meio - cujos resultados conferiam destaque à concepção higiene/educação. Em que pesasse o reconhecimento da primazia das variáveis econômicas, incluindo o salário como indicador real da precária situação alimentar, as classes pobres e as classes abastadas desconheciam os princípios básicos de alimentação e higiene.

Se, para os intelectuais que adotaram o método geográfico, a geografia francesa fornecia suporte metodológico para a compreensão da alimentação, como elemento significativo na formação e evolução social brasileiras, caracterizando os diversos gêneros de vida regionais e desmistificando a versão da fatalidade climática, as produções dos norte-americanos, no campo da fisiologia comparada e da antropologia cultural, foram apontadas, em todo o conjunto da produção, como referências teóricas da maior contribuição para a demonstração da baixa exatidão do determinismo climático, bem como da doutrina racial de Goubineau, que impingia às 'raças inferiores' o atraso social de uma nação. As produções dos norte-americanos, voltadas para a definição dos parâmetros de normatividade fisiológica necessárias à construção do conceito da ração alimentar racional (normal, média), tiveram entrada franca no Brasil, não apenas por intermédio do professor e médico argentino Pedro Escudero, mas também pela aproximação dos intelectuais em foco com estas produções. Não seria o caso aqui de listar todos os interlocutores norte-americanos recrutados nesse processo, mas o de registrar que eles marcaram posição definitiva na produção brasileira, na medida em que, no âmbito do intenso diálogo travado pelos intelectuais com as produções externas e internas, aqueles interlocutores solucionavam, no nível cognitivo, o dilema interno - a reposição da qualidade negada ao homem brasileiro.

Como assinalava Castro (1937), McCollum, por exemplo, mostrava como indivíduos considerados de raça inferior, como a raça amarela, transportados para a Califórnia e bem alimentados, conseguiam ter filhos com uma estatura média bem mais elevada do que nos seus países de origem, do Oriente. Tal desempenho também se verificava nos testes de inteligência, em que os descendentes desta raça se sobressaíam em relação aos americanos. Ficava, então, desvalorizado o preconceito de raça, "que a ingenuidade de uns e a má fé de outros ainda tentavam manter de pé, num momento em que é impossível se 
admitir a pureza racial de um povo" (Castro, 1937:118). Com o preconceito de raça, também foi banido do seu prestígio dominador o outro preconceito o de clima. O clima tropical não era mais nem menos apto à vida humana do que o clima frio. Para Castro (1937), se tivesse que tomar partido, seria para afirmar que o homem era naturalmente um animal dos climas quentes adaptado a outras formas de clima. Por um mecanismo técnico de aclimatação, o homem se diferençava de outras espécies e, quanto a isso, a aclimatação era muito mais uma adaptação inteligente dos seus hábitos do que uma adaptação inconsciente de sua fisiologia individual. Portanto:

No Brasil, mais do que a herança racial e a ação amolecedora do clima, agia como estôrvo à nossa evolução social, impedindo que ele tomasse velocidade como entre os norte-americanos, certas causas de fundo social e econômico, como a rareza do elemento humano diluído em excesso em desmedidas extensões, como a falta de meios de defesa contra o cortejo das chamadas doenças tropicais, a febre amarela, o paludismo, as disenterias, doenças mal conhecidas e mal estudadas que pareciam males irremoviveis, características dos maus ares tropicais, até o dia em que foram dominadas, através do conhecimento de sua patologia pelos métodos profiláticos. (Castro, 1937:124)

As conseqüências dessa alimentação defeituosa, monótona, à base de farinha de mandioca, de conservas e alimentos secos, velhos e estragados, que os senhores ricos faziam vir de Portugal, desdobraram-se em vários aspectos sobre a vida orgânica e psíquica do brasileiro, dando-lhe esse tipo médio de homem fraco e subnutrido, com um peso abaixo do normal, com uma incapacidade crônica para o trabalho, com um índice de longevidade assustadoramente curto e, ainda por cima, com um índice de mortalidade infantil dos mais altos do mundo.

Tais indicadores foram extensivamente explorados por Coutinho (1937), no livro Valor Social da Alimentação, sob a premissa de que a dieta nos colégios de uma cidade constituía-se em expressão da dieta habitual de sua gente. Realizando um inquérito alimentar nos colégios do Rio de Janeiro, ele assinalava que a determinação quantitativa de calorias, proteínas, hidrato de carbono, gordura, sais minerais e vitaminas revelava erros graves. Não havia, entre os escolares, a subnutrição quantitativa (fome), mas a má nutrição como resultado de uma distribuição mal orientada dos alimentos, em que havia excesso de uns em prejuízo de outros, imprescindíveis. As dietas constituíam, em geral, pequenas quantidades de leite e vegetais - alimentos protetores, segundo palavras de McCollum. Uma criança que não recebia tais alimentos e o ovo, em proporção suficiente, era malnutrida. Resultava, dessa deficiência, um excesso de carne e cereais que não forneciam os pequenos elementos da nutrição em quantidades suficientes. 
Quanto a isso, é importante ressaltar que, segundo Coutinho (1937), tal inquérito por ele realizado datava de 1931, quando seu mestre e professor Osório de Almeida sugeriu que ele estudasse os 'regimes alimentares' de alguns estabelecimentos escolares do Rio de Janeiro. Além disso, Coutinho relatava que, pelo que ele conhecia do assunto, só havia, em 1931, o inquérito iniciado pelo Ministério da Educação, então dirigido pelo dr. Francisco Campos; contudo, esse inquérito, embora orientado pelo dr. Carlos Sá, não teve maiores efeitos, representando, portanto, apenas uma tentativa de investigação honesta nesse campo, pois o governo, por intermédio do Ministério da Educação, já demonstrava dar alguma importância à alimentação. De fato, isso indica que antes de 1935 os inquéritos ainda não haviam adquirido a sistematização necessária para assegurar a exatidão científica das investigações coletivas.

Diferentemente de Castro (1937), Coutinho usou o termo má nutrição como um estado no qual o metabolismo do indivíduo estava alterado em conseqüência de uma dieta defeituosa (deficiência de um ou mais fatores nutritivos), enquanto subnutrição era o estado em que se encontrava o indivíduo que recebia uma dieta pobre em todos os fatores nutricionais. Assim, má nutrição era em toda a sua extensão um termo qualitativo e subnutrição, quantitativo. A diferença terminológica destas definições estava no fato de serem a má nutrição e a subnutrição duas modalidades de expressão de estados nutricionais alterados, isto é, manifestações biológicas da fome e da subalimentação que se projetavam na célula, enquanto os termos fome e subalimentação, por si só, pareciam expressar muito mais um determinado nível de consumo.

Para Coutinho (1937), a má nutrição era a modalidade mais grave, porque exigia uma observação cuidadosa, na medida em que era um estado latente de deficiência de um ou mais fatores nutricionais que não apresentavam sintomas de imediato, passando, portanto, despercebida. Em sua extensa revisão bibliográfica, o autor constatava a magnitude desse fenômeno, mesmo nos países mais adiantados, como Estados Unidos, Inglaterra, Dinamarca, Austrália etc., e concluía o quanto era deplorável a falta de critério satisfatório para diagnosticar a má nutrição. Por se constituir a má nutrição em defeitos leves, não se dava muita importância; no entanto, era um fenômeno de importância social muito maior do que os próprios casos de doença declarada, dado que tais defeitos iam minando ocultamente a vitalidade de um povo. Eram defeitos suficientes para diminuir a energia e a capacidade de um agrupamento humano, transformando povos capazes e ativos em apáticos e indiferentes. Um grupo social vivendo em estado de má nutrição era susceptível de apresentar uma porcentagem elevada de cáries dentárias, fertilidade diminuída, ao passo que aumentava o seu 
coeficiente de mortalidade infantil. O coeficiente de morbidez das afecções respiratórias (resfriados, pneumonias, tuberculose etc.) acarretaria o maior aumento. O tempo de vida, o peso e a altura ficavam reduzidos. Era no percalço desses efeitos da má nutrição que Coutinho buscava afirmar o valor social da alimentação, assunto que, para ele, interessava tanto ao sociólogo, como ao legislador e ao político.

No entanto, esse autor se aproximava de Castro, quando assinalava que nesse estado de má nutrição e mesmo de subnutrição, de miséria alimentar, viviam as populações tropicais, a gente dos países coloniais e subcoloniais:

É aos agrupamentos humanos neste estado de miséria que muitos sociólogos $e$ anthropologistas consideram biológicamente inferiores. Attribuem à mestiçagem, às outras raças que não a branca, aquella inferioridade. Inferioridade resultante de factores sociaes e não genéticos ou de raça. (Coutinho, 1937:22)

Como se viu, estava demonstrada a pouca exatidão da teoria racial de Goubineau sobre a desigualdade das raças, adquirindo vigor explicativo a teoria do valor cultural de Franz Boas (professor de Columbia University). Não só a alimentação, como também as condições higiênico-sanitárias precárias influenciavam desfavoravelmente tais grupos sociais, reduzindo a sua eficiência.

Em verdade, Franz Boas, em uma das suas produções, desenvolveu com rigor de detalhes a relação entre raça, linguagem e cultura, por uma extensa abordagem do método antropométrico, confrontando diversas investigações antropométricas da população dos Estados Unidos e de outros países e destacando as variações nos indicadores de crescimento e desenvolvimento de imigrantes em diversas circunstâncias socioculturais: altura, peso, índice cefálico, entre outros. Com isso, o autor aprofundava o entendimento da relação entre a antropologia física e a antropologia cultural na desmistificação das teses raciais (Franz Boas, 1940). A referência usada por Coutinho (1937) e os demais intelectuais em foco foi: Franz Boas (1929).

Para Coutinho (1937), no entanto, o cultural se limitava ao econômico, na medida em que toda a sua argumentação girava em torno do baixo poder aquisitivo da população atingida pela má nutrição. Quanto a isso, o hábito alimentar não adquiriu força explicativa como fator determinante da má nutrição. Embora ele estivesse imbuído da perspectiva de mostrar o valor social da alimentação, mediante a investigação da alimentação coletiva, a exemplo de Castro, acabou por se prender muito mais ao enfoque eugênico da alimentação, distanciando-se dos complexos fatores da organização social. Desse modo, a insuficiência de salário como fator determinante da má nutrição era muito mais 
um dado conjuntural, até porque os escolares do Rio de Janeiro, estudados por Coutinho, eram de classes abastadas.

Nesse aspecto, se nos países de elevado nível econômico (Estados Unidos, Inglaterra, Canadá etc.) havia alta proporção de indivíduos malnutridos, em países como o Brasil tal proporção devia ser excessiva. A esse respeito, Coutinho (1937) indicava a existência de duas classes sociais: classes pobres e classes abastadas. Embora seu estudo estivesse voltado para os escolares de classes abastadas do Rio de Janeiro, ele considerava que tal observação revelava o quanto era inferior o nível nutricional do brasileiro. Por um exercício de abstração, ele deduzia das classes abastadas que as condições alimentares e higiênicas das "nossas classes pobres eram miseráveis, resultado de seus salários insufficientes" (Coutinho, 1937:26). Tinham estas classes, como sustento, a farinha, o charque ou bacalhau, três alimentos pobres; no entanto, os mais acessiveis aos seus bolsos, aos quais acrescentavam às vezes o feijão, que já era 'um luxo', e o toucinho.

Nesse enfoque, não eram apenas as endemias rurais as responsáveis pelo estado de inércia, pouca capacidade de trabalho e produtividade em que vivia o brasileiro, especialmente o trabalhador rural. E muito menos culpa tinha o clima. O operário das cidades, embora recebesse um salário superior ao do homem do campo, também vivia em miséria alimentar. Para essa argumentação, Coutinho (1937) se fundamentava nos inquéritos realizados em São Paulo, por Souza (1935) e Davis (1935), bem como o de Castro (1935), realizado em Recife. Quanto a isso, é interessante notar que, embora Castro (1937) e Coutinho (1937) enfocassem classes sociais diferentes em seus estudos, o processo de generalização obedecia à mesma lógica, considerando o uso da noção de região. Era por referência a uma região estudada que a situação alimentar global do País podia ser inferida.

No conjunto da produção, o termo 'classe' foi usado pelos intelectuais como categoria descritiva para acentuar a existência de duas classes sociais diferentemente designadas: 'classes pobres' e 'classes ricas'. Ao que tudo indica, tais classes eram representadas por um agrupamento humano que se encontrava na mesma situação, cuja relação entre as classes se dava apenas no plano da produção e do consumo. Se, no plano da produção, elas se diferençavam, marcando a desigualdade entre pobres e ricos, no plano do consumo alimentar elas se igualavam pela ignorância, daí o desregramento que marcava o desequilibrio da ração.

Porém, vale antecipar que, no conjunto da produção em foco, Coutinho (1937) foi o autor que mais relativizou a importância e a eficácia de uma 
campanha de educação alimentar, na medida em que deu maior ênfase ao fator econômico como causa determinante da má nutrição. Nesse aspecto, ele se aproximou dos estudos de Sherman, realizados em 1932, e de Jones, em 1933, que mostravam que nos Estados Unidos as famílias que possuíam maior orçamento gastavam maior percentual de dinheiro com a alimentação, sendo a proporção de cereais da dieta uma razão inversa das condições econômicas das famílias. Assim, era "verdade que uma melhor orientação dietética, um conhecimento mais exato dos valores alimentares, farão essa gente distribuir com mais acerto o dinheiro destinado à compra de alimentos" (Coutinho, 1937:33). As melhoras dietéticas resultantes de uma boa orientação, no entanto, seriam leves. Só com a elevação do nível econômico das populações seria possível produzir boa nutrição, o que não era possível, segundo ele, com aquela organização social. Com isso, estava posto no plano da causalidade o debate em torno de duas categorias centrais no processo de constituição da educação alimentar: a pobreza e a ignorância.

Para o autor, somente as classes ricas e remediadas superalimentadas, mas não bem alimentadas, seriam beneficiadas com a campanha da boa alimentação, embora junto às classes proletárias se produzissem resultados leves. Contudo,

Seria aconselhável a creação de cursos dietéticos desde as classes primárias, cursos que, bem orientados, dariam às crianças um sentido real da alimentação e dos seus verdadeiros valores. Desapareceriam muitos preconceitos alimentares, às vezes tão fortes, no que diz respeito à mistura de certos alimentos, também muita noção errada sobre nutrição. (Coutinho, 1937:334-335)

A esse respeito, Roquette Pinto, no prefácio ao livro de Castro (1936), Alimentação e Raça, assinalava que os trabalhadores brasileiros davam muito mais do que se esperava, à vista do pouco que consumiam. "Não faltam, porém, estudiosos para afirmar que o brasileiro 'não sabe comer', alimenta-se mal por ignorância". Para Roquette Pinto, em certa medida, isso era verdade, mas ele pensava que o trabalhador aqui não comia como devia porque não podia. $\mathrm{A}$ ignorância agia como fator indireto. Por causa dela, ele não sabia criar e defender a riqueza. Entregava tudo, sem revolta, nem protesto; não cobrava, por causa da educação escravagista que lhe deram, o que tinha direito de receber para não viver na miséria.

Isso indica que era exatamente por meio de diferentes enfoques que o objeto da educação alimentar ia sendo concebido, bem como o arcabouço teóricometodológico pelo qual esse campo afirmava sua base cognitiva. Foi com o livro de Messias do Carmo (1937), Política Alimentar Nacional, que a educação alimentar passou a ganhar maior expressão e significado, tendo por base mesmo 
a delimitação do instrumental de investigação. $O$ inquérito alimentar foi por ele aperfeiçoado, sob a premissa de que nenhuma campanha de alimentação poderia ser eficiente, sem que previamente fossem procedidos inquéritos para um conhecimento minucioso de três elementos importantes: a população, a produção $e$, por fim, o modo pelo qual o povo se alimentava. Com esses três conhecimentos é que poderia ser programada uma política de alimentação visando racionalizar a produção, para tornar bem acessível o padrão de vida do povo e aconselhar as melhores normas de aquisição dos gêneros alimentícios dentro dos preceitos de higiene alimentar. A preocupação era, então, estabelecer os detalhes da metodologia dos inquéritos sobre alimentação popular, de modo a instrumentalizar um plano de política alimentar. Dessa forma, ele alertava que tratava de temas gerais, deixando detalhes da alimentação popular para outro trabalho. Com isso, não estava em questão o deciframento dos contornos da fome e da subalimentação em suas diversas manifestações, mas a dimensão política desse problema como instância definidora dos ingredientes normativos de um plano para combatê-lo.

Para isso, organizou um plano de inquérito dividido em dois tipos: diretos e indiretos, que pudessem ser aplicados a todos os meios. Os primeiros deviam ser aplicados por especialistas in loco, indo surpreender as pessoas em seus hábitats, nos meios coletivos; os segundos deviam ser aplicados por meio dos ambulatórios, das escolas, das associações, das fábricas etc. Qualquer dos dois contava com folhas impressas, contendo de forma metódica os dados que se desejava obter.

Os inquéritos indiretos foram divididos em três tipos:

- popular;

- para pessoas de preparo geral;

- para pessoas de preparo científico.

No primeiro, deviam ser coletados apenas dados imediatos; no segundo, era importante descer a detalhes informativos sobre consumo de leite, facilidade de plantação de hortas para maior consumo de vegetais; no terceiro, para pessoas de preparo científico, deviam ser pedidos todos esses informes e as observações e sugestões pessoais. Ao lado dos informes de nutrição, deveriam ser solicitados os dados antropológicos mais importantes, como idade, cor, cabelo, altura, peso etc., aí juntando-se as características familiares, compreendendo os antecedentes mórbidos, sobretudo em relação a moléstias da nutrição, como diabetes, obesidade etc. Nessa abordagem, o inquérito devia ser antecedido de uma palestra ilustrativa, em linguagem bem simples e acessivel, dando a conhecer a necessidade de serem fornecidos dados exatos, para que fosse possivel, em troca, apontar 
conselhos e esclarecimentos sobre as melhores normas de alimentação sadia e barata. Condenar o desperdício em bebidas alcoólicas, em prejuízo da alimentação, $e$ aconselhar o emprego desse dinheiro em frutas, verduras e leite.

A importância da tomada desses dados biométricos resultava da necessidade de se estabelecer, conjuntamente com o problema geral da alimentação, os subproblemas de conhecimentos do homem, dos chamados biotipos brasileiros, a fim de que se pudesse estudar, o mais intimamente possível, os fenômenos e epifenômenos que condicionavam o complexo nacional de melting pot, em cuja clivagem poder-se-ia surpreender um dia o tipo eugênico médio, nunca o ideal, inatingivel, porém aquele possuidor da menor soma de defeitos e o maior conjunto de atributos. Quanto a isso, segundo Carmo (1937), havia observação muito oportuna de Oliveira Viana, acerca da tomada de dados antropométricos. Um bom caminho nesses questionários, verdadeiras fichas pelas quais indiretamente se procede a um meio recenseamento e à ampla apreciação sobre os tipos brasileiros, era dar certa elasticidade e liberdade aos informes, usando mesmo denominações sem caráter técnico rigoroso, quais sejam, ao lado das cores: 'branco e preto', que eram fundamentais, empregar também 'pardo, moreno, caboclo' etc., assim como na dos cabelos não deixar de mencionar 'lisos', 'crespos', 'enrolados' e os característicos 'pretos, 'castanhos' e 'louros', bem como anotar as tonalidades dos olhos - negros, castanhos e azuis. Esses poucos dados, combinados entre si e com os biométricos - altura, peso e perímetro torácico - dariam, ao juízo de quem ia fazer a crítica das fórmulas propostas, elementos mais do que suficientes para um julgamento antropológico rudimentar. Ressaltava ainda o autor a importância dos alistamentos eleitorais que traziam dados, como: nome, filiação, estado civil e profissão; as carteiras profissionais, as dos estudantes, os passaportes e tantos outros documentos obrigatórios a que os indivíduos não se poderiam furtar.

Na perspectiva de testar o método indireto, Carmo (1937) realizou pessoalmente um inquérito na Escola Cristo Redentor, na Penha (Distrito Federal), com 180 crianças divididas em duas turmas, para as quais foi desenvolvida previamente uma palestra explicativa. Prêmios foram instituídos para os alunos que levassem as melhores respostas, situação em que o autor revelava ter assistido com surpresa a um sucesso que não esperava. O êxito havia sido completo, pois as fórmulas foram desenvolvidas com respostas aos três itens que ele tinha em vista: informações sobre o salário, o modo de alimentação e dados antropométricos e censitários.

Para Castro, os resultados do inquérito deixavam claros, com base nas regras de Sherman, que havia um grande empirismo na compra de gêneros. Em 
muitas fichas preenchidas, a quantidade de gêneros comprados excedia quase o dobro do esperado, havendo mesmo desperdício de gêneros, dado que eles eram comprados e não utilizados. Assim, as principais causas de erro eram: o desperdício, o empirismo e a compra de grande quantidade de provisão que ficava em estoque. Dentro desses três itens podia ser organizada a campanha de higiene alimentar:

- de economia doméstica;

- de organização de cardápios de acordo com a regra de Sherman;

- para impedir armazenagens em lugares obscuros, dando lugar à adulteração e à contaminação dos alimentos.

Além disso, ao testar o instrumento de pesquisa, o autor verificou que havia desencontro nas informações prestadas, daí a necessidade do controle do seu uso em investigações coletivas.

Com esse enfoque de Carmo (1937), fica evidente que o inquérito alimentar como instrumento técnico a serviço do método geográfico comportava um verdadeiro meio de recenseamento do perfil alimentar e do padrão de vida do povo. Nesse percurso, adquiriam expressão as orientações da Sociedade das Nações, como instituição que se voltava para a definição de parâmetros técnicos normativos e uniformizadores de pesquisa coletiva para uso universal, delimitando, por exemplo, a base de ação que poderia conduzir a pesquisas de caráter prático com populações juvenis (pré-escolar, escolar e adolescentes), à luz dos indicadores: idade, sexo, aparência física, peso e altura, associados a um exame clínico complementar, o que permitiria uma separação entre normais e desnutridos. Pesquisas complementares mais profundas, visando estudar os dados obtidos no primeiro tipo, incluíam dados sobre a alimentação da criança, dados econômico-sociais das famílias e exame médico completo.

Nesse aspecto, é interessante notar que, embora Mendonça (1938) tenha também desenvolvido a noção de região, no livro Noções Práticas de Alimentação, não desenvolveu inquéritos coletivos sobre alimentação. Com base nos inquéritos alimentares já disponiveis, argumentava ele que em todas as regiões brasileiras havia erros fundamentais de dietética - o maior deles era o da subalimentação, freqüente nos habitantes das zonas rurais e na população pobre dos centros urbanos. O baixo nível de pobreza anônima e, algumas vezes, as crenças errôneas transformadas em hábitos representavam perigosos motivos de erros de alimentação. Para Mendonça, as causas da subalimentação qualitativa estavam na ignorância, no analfabetismo e mesmo em conhecimentos negativos das classes abastadas. Nos centros urbanos das grandes cidades, os erros dietéticos não eram de menor vulto, não obstante as condições de vida serem mais favoráveis 
pela civilização, hábitos e costumes. Isso ainda não havia eliminado os erros de alimentação, mesmo nas classes ricas e abastadas que, por falta de conhecimentos dietéticos, privavam-se de alimentos úteis, como o leite. Era entre os pobres, no entanto, que os erros de alimentação se mostravam mais elevados e de maior significado social.

Nesse aspecto, Mendonça distinguia dois tipos de subalimentação. A quantitativa global era resultante das condições de pobreza. A unilateral (qualitativa), porém, constituía um dos mais importantes fatores de desprestígio e inferioridade biológica, dado que se tornava um imperativo de diminuição física, reduzindo a vitalidade racial.

Tal modalidade de subalimentação, que privava o indivíduo de determinadas espécies de alimentos, era a forma mais grave de depauperação do indivíduo e da raça, visto que perturbava o crescimento, diminuía a resistência orgânica, criava a constituição mórbida e fazia nascer débeis e incapazes que se extinguiam na terceira geração. Já a insuficiência global (quantitativa) de alimentos era a de menor gravidade, porque caracterizava a fome que levava o homem às revoluções, às guerras e ao crime, em defesa da espécie. Na zona dos sertões, o indivíduo chegava, às vezes, ao máximo da subalimentação unilateral (qualitativa), com o consumo exclusivo de carne seca, peixe seco, rapadura e farinha de mandioca. Essa alimentação sem vitaminas era a principal causa da pequena resistência e incapacidade de trabalho dos habitantes dessas zonas. Em tais regiões, era escasso o consumo de verduras e frutas.

Como problema eugênico, esse fenômeno era de perigosa conseqüência social, porque depauperava o homem, reduzia a capacidade de trabalho, diminuía a longevidade e debilitava as gerações subseqüentes. Isso se expressava nos índices da média de vida no Rio de Janeiro, que era de $23,1 \%$ com uma mortalidade de $42,5 \%$ até os 9 anos, $47,4 \%$ até os 19 anos, $60,0 \%$ até os 29 anos e $85,8 \%$ até os 59 anos. Tal realidade indicava que, se de um lado, o homem representava capital que produzia e acumulava, de outro, o Brasil apresentava características desfavoráveis quanto a isso, pois a riqueza e o progresso de um país eram a conseqüência, segundo Mendonça (1938), da porcentagem de sobreviventes na faixa de 20 a 60 anos.

Desse modo, os intelectuais, ao descartarem as teses racistas que, fundadas em atributos genéticos, ancoravam critérios de seleção social, concebiam a fome e a subalimentação como fenômeno universal e fator de degeneração racial, na medida em que, embora de modos diferentes, tal fenômeno atingia pobres e ricos, inclusive. Disso resulta que o trabalhador era também concebido em sua universalidade, pois trabalhador era todo aquele que produzia. 
Diferentemente de Coutinho, Mendonça (1938) deu maior ênfase ao hábito alimentar do que ao fator econômico. Como fenômeno ecológico, o hábito alimentar era decorrência do processo de adaptação do homem ao meio em que vivia, caracterizando um processo natural (e não cultural). Sob essa ótica, a alimentação de cada povo dependia sobretudo das possibilidades do meio natural, da região em que habitava. Nas regiões úmidas, a alimentação era predominantemente à base de folhas, enquanto nas regiões secas predominavam os produtos animais. Quanto a isso, eram as possibilidades de alimentação nas diversas regiões da terra que criavam os hábitos que dominavam e não podiam ser modificados por processos rápidos de dietética, sem prejuízos para a saúde. Isso só seria possível se houvesse modificações nas condições do meio, como fenômeno natural e econômico. $\mathrm{O}$ longo trabalho de adaptação criava o tipo de alimentação ótima de cada povo, inerente ao que o solo produzia.

A despeito disso, Mendonça reconhecia que em todas as regiões do Brasil havia erros de dietética que só poderiam ser solucionados pela adoção de um padrão dietético racional, pautado em regras para bem comer. A título de demonstração, procedeu, em 1938, ao mapeamento dos hábitos alimentares brasileiros por região:

- região Amazônica-Equatorial, onde predominava a cozinha indiática à base de produtos de mandioca, como a farinha-d'água, a tapioca, e o tucupi, o cupuaçu, o bacuri, a bacaba e o assaí, sendo muito usada a caça de moquém pela gente dos seringais;

- região dos sertões tropicais, seca, com características da cozinha sertaneja, rude, primitiva e variável, conforme as condições locais, à base sobretudo de carne seca, requeijão e rapadura;

- região do litoral-tropical úmida, em que a cozinha recebeu as influências imigratórias, sobretudo na cozinha baiana. No litoral Nordeste era grande o uso do coco da praia e do açúcar de cana;

- região do Centro-Sul - subtropical, cuja cozinha era variável, à base de produtos regionais, de origem agrícola (cozinha mineira); e

- região do extremo-Sul - temperada, com as características da cozinha gaúcha, em que a carne e o mate eram os alimentos predominantes.

Com isso, o autor fortalecia a tese de que, no Brasil, comia-se mal porque não se sabia comer. A desarmonia alimentar, constatada em todas as regiões, residia na falta de conhecimentos gerais sobre a matéria. Por isso, precisava-se saber comer. Devia-se conhecer o teor nutritivo dos alimentos. A melhoria do padrão alimentar, o ensino nas escolas e a divulgação dos conhecimentos necessários constituíam o meio mais seguro para atingir as vantagens da alimentação, do duplo ponto de vista do indivíduo e da coletividade nacional, pois: 
A arte de saber comer não é a de comer bem, é satisfazer as necessidades do organismo, dentro das possibilidades de cada um (...). A parte principal na alimentação do pobre, particularmente o trabalhador braçal, é saber aproveitar o máximo de valor nutritivo, com o mínimo de dispêndio, mantendo a harmonia alimentar e satisfazendo as necessidades calóricas do organismo. (Mendonça, 1938:82)

Muito próximo de Mendonça quanto ao enfoque sobre o hábito alimentar esteve Botelho (1938), no livro Os Pequenos Fundamentos da Bôa Alimentação. Sua perspectiva era falar, 'por alto', como se alimentava o povo. Comparando a composição da alimentação usual com o que era preconizado como alimentação racional evidenciava-se a falta de alimentos essenciais e outros erros básicos da alimentação. Contudo, ele não realizou inquéritos alimentares, pois frisava que se poupava desse trabalho "ingrato" de descrever sobre o próprio déficit alimentar, voltando-se muito mais para a descrição geográfica dos hábitos alimentares regionais.

Quanto a isso, reiterava um dos postulados de Pedro Escudero: "nada tem resistido tanto à corrente da civilização como a arte de comer" (Botelho, 1938:5). Enquanto a própria arte de vestir passava por mudanças, a de comer persistia nos mesmos moldes antigos, sendo os avanços muito remotos. No Brasil, perseveravam, na maioria dos territórios, os remanescentes hábitos alimentares luso-africanos que, se pelo lado português eram incompatíveis com o clima, pelo africano, atentavam contra a própria civilização. Tal problema era meramente de educação. Evidencia-se, então, no conjunto da produção em foco, a existência de uma tendência que explicava a formação e a persistência dos hábitos alimentares por um processo histórico linear e contínuo, desqualificando a dietética popular e acentuando a noção de resistência à mudança.

Botelho (1938), todavia, argumentava que o problema do 'capital-alimento' estaria bem resolvido em conseqüência da valorização do homem como 'capital' da nação. Seria pela alimentação racional que se melhoraria, não só sob o ponto de vista individual ou biológico, mas, ainda, sob o ponto de vista coletivo ou econômico-social, o que não tinha substituto: o homem brasileiro sadio.

A exemplo de Castro, Carmo e Mendonça, Botelho (1938) também adotou a noção de região para conhecer a alimentação habitual do Brasil. Nesse aspecto, a região era concebida como unidade autônoma, sendo o País dividido em quatro regiōes, sob a premissa de que dentro de cada uma havia uniformidade básica alimentar com pratos alimentares absolutamente característicos para cada estado. Ei-las: 
- primeira região - Vale Amazônico - caracterizado pelo uso do peixe, sendo o pirarucu fresco, ou em conserva, o prato habitual. A mixira, que era a conserva na sua própria gordura do peixe-boi, era prato freqüente na mesa dos habitantes desta região, além da farinha-d'água, o tucupi e o tacacá;

- segunda região - Norte e Nordeste - caracterizada pelo uso da carne, especialmente a de cabrito, seca ao sol ou ao vento. Além disso, o milho e o leite tornavam substancial a alimentação. No litoral, as frutas aumentavam o valor da alimentação;

- terceira região - Sul - onde havia o predomínio da carne fresca em forma crescente de churrascos e a carne seca com angu de milho, feijão e farinha, que constituíam a base da alimentação das classes mais abastadas; $e$

- quarta região - estados centrais - caracterizada pelo uso da carne fresca, sobretudo de vaca e de porco. O leite e derivados, o milho e os legumes tornavam a alimentação mais saudável.

Nesse ponto, vale assinalar que, embora a tendência explicativa que fez uso do método geográfico tenha-se orientado em maior ou menor grau em torno de um eixo comum - as características da organização social -, ela se diversificou na eleição das categorias de estudo da fome e da subalimentação, priorizando diferentemente, mas de modo complementar, quer por estudos teóricos (como Botelho), quer por investigações empíricas (como Castro, Carmo e Coutinho), aspectos como: economia, monocultura, salário, pobreza, hábitos alimentares, ignorância.

Afastando-se desse enfoque, Costa (1938), no livro Bases da Alimentação Racional, não esteve voltado para a realização de inquéritos alimentares coletivos, nem para o uso do método geográfico, fazendo rápidas referências aos erros de alimentação no sertão e nas cidades, à luz dos inquéritos realizados em São Paulo e em Recife. Por referência aos resultados de tais estudos, reiterava que o Brasil se alimentava mal. A maioria comia erradamente, nutriase mal, quando era fácil se alimentar bem, desde que se aprendesse, na escola, a comer. Conhecendo, como já conheciam na época, as bases científicas da alimentação, era fácil começar em cada casa brasileira um trabalho de reeducação alimentar. Para ele,

Comêr carne seca e farinha, como faz o sertanejo, não é alimentar: é matar a fome e não satisfazer à vida. O sulista, este consome uma porção maior de carne, de proteína (...). De que vale um excesso de churrasco com farinha, sem alimentos que contenham vitaminas, sais e gorduras? É apenas e sempre apenas matar a fome. Não é alimentar-se racionalmente. (Costa, 1938:214-215)

Se o trabalhador brasileiro alimentava-se mal, as pessoas abastadas não sabiam comer. Abusavam quase sempre das proteínas, das gorduras e dos hidratos 
de carbono, engordavam, envelheciam, tornavam-se improdutivas. Dois males se somavam para a maior deficiência nacional: o pauperismo e a ignorância. $\mathrm{O}$ pauperismo era limitado aqui, como no resto do mundo: só o sentiam as grandes massas trabalhadoras, cujo rosto suava no cansaço de todos os dias e cujas mãos produziam o que o País gastava. Mas a ignorância era geral: os que podiam e os que não podiam comer bem comiam sempre mal.

Nesse enfoque, tais erros vinham de muito tempo. Afinal, herdamos pratos indígenas, africanos, portugueses, quase todos inadequados às nossas condições. Diferentemente de Mendonça e Botelho, Costa deu ênfase ao processo histórico de modificação da alimentação dos povos, situando cada etapa que modificou esse ou aquele hábito como resultado do processo civilizatório: "Civilizar é modificar os velhos hábitos, para melhor, é receber o que de novo e de bom a inteligência dos homens for criando" (Costa, 1938:39). Após passar pelas Idades Primitivas e a Idade Média, com suas influências na alimentação de cada povo, voltou-se o autor para o desenvolvimento urbano-industrial, nos meados do século XX, que impingiu modificações significativas na alimentação para melhor e para pior, e, neste último caso, as mudanças não eram sentidas pelo povo, a exemplo da substituição do pão integral completo pelo pão branco. $\mathrm{O}$ desenvolvimento urbano-industrial operou deslocamentos no modo de vida das populações urbanas e rurais e nos sistemas produtivos que, entre outras coisas, encareceu os produtos agrícolas. Foi assim, então, que se difundiu o hábito de comer cereais (arroz, trigo, feijão, milho, aveia etc.) para suprir a falta e o alto custo dos alimentos de maior valor nutritivo.

Sorre (1955), ao recuperar esse percurso de mudanças na alimentação desde o século XVIII, nos marcos do método geográfico, assinala que em algumas gerações se consumou uma verdadeira revolução alimentar e de alcance profundo, de modo que não se pode calcular a extensão de suas conseqüências. Dois fatores teriam concorrido para isto: a rápida elevação dos níveis de vida e a irradiação das influências urbanas. Tal revolução começou nas cidades, onde o mercado reunia os produtos da terra, graças ao progresso dos transportes. Essa revolução se propagou primeiro lentamente, depois com velocidade acelerada no transcurso das últimas décadas daquele século. À medida que se atenuavam as diferenças de região a região, suprimia-se o que distinguia a alimentação das classes. Além disso, uma multiplicidade de alimentos novos foi introduzida. Nos países da Europa central e oriental, seus efeitos maiores se registraram nas cidades. A alimentação campesina não sofreu transformações em todas as partes, ainda que em certos casos assimilasse os progressos da alimentação urbana, pois os mercados das cidades estenderam o seu raio de compras graças à maior facilidade 
de transportes. Assim, persistia nesses países o regime alimentício tradicional. Os regimes não urbanos ainda marcavam a diversidade regional nos países da Europa ocidental, sobretudo na França. Neste país, a alimentação das populações rurais mostrava sinais de arcaísmo até o final do século XVIII, com seu predomínio de pão preto e papas como alimentos básicos, em detrimento das verduras. A despeito disso, a França foi o primeiro país onde se generalizou o uso do pão branco. Assim, tudo que no passado era elemento de diversidade se atenuava progressivamente ante a generalização dos regimes alimentícios urbanos. Ao tempo em que se elevava a proporção de homens que viviam nas cidades, a propagação dos níveis de vida se estendia, e os ambientes rurais assimilavam cada vez mais os ambientes urbanos - sem considerar as diferenças de suas necessidades.

As substâncias protéicas passaram a ocupar importante lugar na alimentação urbana. Quanto a isso, Sorre (1955) compara a porcentagem de calorias animais nos Estados Unidos (39,2\%), país altamente urbanizado, com a da China do Norte, país rural e vegetariano (apenas 1\%). No ano de 1930, na França, por exemplo, o coeficiente de proteínas animais (considerando as proteínas totais iguais a 100, nas populações rurais) alcançava 193 nos meios urbanos. Para o autor, dentre todas as transformações que haviam ocorrido na economia rural e da técnica agrícola, desde o século XVIII, levando à ampliação da área e à transformação dos mercados, a urbanização tem de ser posta em primeiro plano, a considerar a evolução do consumo anual de proteína por pessoa no período de 1930 a 1934 em quilogramas: Argentina, 120,8; Nova Zelândia, 103,8; Austrália, 91,5; Canadá, 65,4; Reino Unido, 63,7; Dinamarca, 62,4; Estados Unidos, 61,9; Estônia, 53,4; Alemanha, 51,1; Suíça, 47,3; Países Baixos, 45,6; França, 43,5 etc. Essas mesmas observações podiam ser feitas a propósito dos glicídios.

Outra causa que tinha estimulado esse fenômeno eram os progressos da indústria, que oferecia ilimitados recursos na oferta de alimentos processados e na alimentação feita fora de casa, liberando a mulher que trabalhava fora dos afazeres domésticos. Quando não se comia no restaurante, o recurso apressado aos produtos preparados liberava de toda preocupação a mulher em relação a sua casa. O consumo de alimento puro, desembaraçado de impurezas, às vezes subștâncias de grande valor nutritivo, completava o que existia de artificial nesse gênero de alimentação.

De fato, segundo Hobsbawm (1977), em 1848 a população mundial ainda consistia de homens do campo. Mesmo na Inglaterra, a primeira economia industrial, a população da cidade não era mais numerosa do que a do campo 
até 1851. A partir do fim da década de 1870 , a situação havia-se modificado substancialmente, mas, com algumas poucas exceções, a população rural ainda prevalecia em grande número sobre a urbana. Nesse aspecto, é importante mencionar que parte crescente da agricultura tinha em comum, por todo o mundo, uma sujeição à economia industrial mundial. Suas demandas multiplicavam o mercado comercial para produtos agrícolas - a maior parte alimentos e matérias-primas para a indústria - tanto internamente como internacionalmente. Sua tecnologia tornava possível trazer regiões, outrora inacessíveis de forma efetiva, para as fronteiras maiores do mercado mundial, por intermédio da estrada de ferro e do vapor. As convulsões sociais, que sucederam a transferência da agricultura para um modelo capitalista, fizeram com que os homens perdessem os laços tradicionais com a terra de seus ancestrais, especialmente quando estes descobriram que não ganhavam praticamente nada dela, ou pelo menos ganhavam muito pouco para manter suas famílias. Simultaneamente, a demanda insaciável de trabalho por parte das indústrias e ocupações urbanas, a diferença crescente entre o campo atrasado e a cidade avançada, com seus estabelecimentos industriais e ocupações urbanas, atraíamnos de qualquer maneira.

Assim, migração, urbanização e industrialização andavam juntas, processo esse que se acentuou no século XIX, quando os países mais atingidos (Estados Unidos, Austrália, Argentina) tinham uma taxa de concentração urbana não superada em nenhum outro lugar, exceto na Inglaterra e nas partes industrializadas da Alemanha. Esse mundo, no entanto, não consistia apenas de fábricas, empregadores e proletários ou da transformação gerada pelo enorme progresso de seu setor industrial. Por mais espantosos que fossem esses fatos, não eram suficientes para medir o impacto do capitalismo. A cidade e o fenômeno de urbanização constituíam, sim, os mais impressionantes símbolos do mundo industrial, e quanto mais as cidades cresciam, mais se intensificava o 'cortiço' e a superpopulação. Porém, "A promessa do marechal-de-campo não tinha a intenção de promover todos os soldados a marechais" (Hobsbawm, 1977:229). Os baixos salários dos trabalhadores e o fenômeno de exclusão geravam a pobreza e a miséria e, por conseguinte, a fome e as doenças. ${ }^{17}$

No Brasil, o panorama da segunda metade do século passado já diferia muito da primeira metade, a começar pelo crescimento demográfico. Se, em 1825, a população era de 5 milhões, em 1890 passou a ser de 14.333 .915 (Prado Júnior, 1978). A modernização do País já se fazia sentir por meio das

${ }^{17}$ A este respeito, ver BRESCIANI (1992). 
estradas de ferro, do sistema bancário, da introdução da maquinaria e do relativo desenvolvimento industrial. Isso não significa que houvesse alterações estruturais naquele período. Ao contrário, afirmava-se a cultura cafeeira, acentuando a dependência agrícola da economia brasileira que, baseada na monocultura, permanecia submissa a flutuações dos mercados consumidores (Pinto, 1990). Segundo Fausto (1976), no entanto, a partir de 1890, a cidade de São Paulo começou a crescer em ritmo acelerado, pois sua população passou de 64.934 habitantes, nesse ano, para 239.820 em 1900, registrando aceleração de $268 \%$, em dez anos. Ainda em 1890, essa cidade já contava com 121 estabelecimentos que se utilizavam da energia mecânica, dos quais 52 eram realmente industriais. Com isso, se intensificava o processo de urbanização, dando surgimento aos bairros operários, local de instalação de fábricas e moradia de trabalhadores. Isso se deveu tanto à consolidação daquela cidade como grande mercado distribuidor, como ao fluxo de imigrantes externos, via política de imigração subvencionada pelo Estado. No fim do século passado, a capital de São Paulo já concentrava 10,5\% da população do estado, índice que chegou a 12,9\%, em 1920. No início do século XX, São Paulo passava a ser a segunda cidade brasileira, embora ainda distante dos 688 mil habitantes da Capital Federal.

O Rio de Janeiro, diferentemente de São Paulo, reuniu também contingentes de população em proporção superior às limitadas necessidades do setor industrial e dos serviços, mas isto se deu mediante a atração exercida pela Capital da República sobre os migrantes internos de todo o País, o que não significa dizer que a entrada de estrangeiros pelo porto do Rio de Janeiro não tenha mantido um fluxo significativo. Entre 1800-1900, esta cidade recebeu imigração líquida de 70.298 estrangeiros, superada apenas por São Paulo (412.297). Entre 1900-1920, o total chegou a 85.590 pessoas, índice somente inferior ao do estado de São Paulo, com a cifra de 274.250 (Fausto, 1976); mas, a partir de 1920, o cenário começava a mudar. Essas duas cidades receberam grandes contingentes das migrações do norte e nordeste do País. O número de operários crescia de 275.512 em 1920 (dos quais 136.135 eram brasileiros, sobre 93.130 estrangeiros) para 420 mil em 1930, sendo sua maior concentração em São Paulo e no Rio de Janeiro - pólos de maior dinamismo econômicoindustrial (Carone, 1975a).

O fenômeno industrial, contudo, se acelerou durante a Primeira Grande Guerra (1914-1918). O censo de 1920 indicava que os estabelecimentos industriais somavam 13.336, dos quais 5.936 tinham sido fundados no qüinqüênio 19151919. A sensivel modificação foi a transferência para o primeiro lugar das indústrias de alimentos, que passava de 26,7\% em 1907, para 40,2\% em 1920 (Prado 
Júnior, 1978). Isso se devia ao aparecimento no cenário de uma nova indústria que tomava vulto durante a Primeira Grande Guerra: a de congelamento de carnes. Nesse ponto, as indicações de Sorre (1955) sobre a revolução alimentar que se processou em maior ou menor grau nos diversos países do continente, incrementando sobretudo o consumo de carne no início do século XX, encontra ressonância nas argumentações de Prado Júnior (1978), quando assinala que o crescimento da indústria alimentícia no Brasil, notadamente a da carne de procedência americana, se fez sentir durante a Primeira Grande Guerra, estimulada pelo crescente consumo dos países beligerantes. Nessa perspectiva, tais indústrias não visavam ao mercado interno, mas ao aproveitamento da matéria-prima abundante no País e à exportação de carne para a Europa que, em 1918, chegava a 60.509 toneladas. Segundo Fausto (1976), os ramos têxteis e de alimentação representavam cerca de $60 \%$ do valor da produção industrial em São Paulo, o mesmo ocorrendo no Distrito Federal. As atividades agrícolas, no entanto, ainda eram as predominantes, pois, em 1920, abrangiam $69,7 \%$ da população ativa.

O processo de modificação dos hábitos alimentares descrito por Costa (1938) pode ser, assim, ilustrado por um dos fatos de mudança polêmico no modo brasileiro de se alimentar. Com o fenômeno da urbanização e industrialização do País, teve início, como assinala Coradini (1982), a substituição do seio pela mamadeira, em meio à sofisticada tecnologia de propaganda adotada pela indústria Nestlé - uma das maiores indústrias multinacionais, que também se instalou aqui em 1921, passando a exercer o domínio sobre a produção, a industrialização e a comercialização do leite e derivados.

A tomar por base as reflexões de Costa (1938), tais modificações nos hábitos alimentares eram possíveis, mas ainda não visíveis no Brasil, conforme a visão dos demais explicadores, segundo os quais persistia, na década de 30 , um regime arcaico/tradicional, não condizente com os novos tempos, cuja deficiência alimentar era caracterizada exatamente pela quase ausência de carne, leite, ovos, verduras, legumes e frutas, tanto nas populações rurais como nos centros urbanos. Para Costa (1938), contudo, se a história mostrava que a alimentação sofria modificações após um período de tempo, reorientando hábitos e civilizando, era possível o Brasil corrigir os erros alimentares que há muito o acompanhava. A falta de educação alimentar constituía, então, para ele, um dos males do Brasil, país de homens desnutridos, ao contrário dos Estados Unidos, cujo povo era composto pelos satisfatoriamente nutridos. Quanto a isso, o Brasil já dera o primeiro passo oficial para a solução do problema, com 
a instituição da Campanha Nacional pela Alimentação da Criança, em 1935, dirigida pelo professor Olinto de Oliveira, realizada pela Divisão de Amparo à Maternidade e à Infância. ${ }^{18}$

Ao tratar do valor social da alimentação, Costa recuperou, além das palavras do orientador da pediatria brasileira, Olinto de Oliveira, os esforços dos mestres Austregésilo de Ataíde, Afrânio Peixoto, Annes Dias e dos pesquisadores Hélion Póvoa, Barros Barreto, Afrânio do Amaral e Paula Souza, que não se cansavam de trazer a advertência e o conselho da experimentação às novas gerações de médicos, para que situassem o problema e procurassem resolvê-lo dentro do quadro das maiores necessidades do País. Nesse ponto, vale destacar que, embora Costa (1938) não tenha feito uso do método geográfico, visava promover um deslocamento do enfoque sobre a alimentação do plano do interesse individual para a coletividade, na medida em que, como problema eugênico, a alimentação influenciava no desenvolvimento dos grupos sociais, traçando-lhes o destino: "A alimentação é um dos principais fatores de felicidade social" (Costa, 1938:122).

A esse respeito, Moscoso (1939), no livro Alimentação do Trabalhador, salientava que os erros da alimentação do trabalhador eram simplesmente uma modalidade, uma amostra da viciosa alimentação geral, em todas as classes e meios. Aproximando-se de Costa (1938), não realizou inquérito nem desenvolveu o método geográfico, referindo-se a um trabalhador teórico, à luz dos inquéritos realizados em São Paulo - pólo mais dinâmico da economia. Com isso, Moscoso atestava que a alimentação não era nem razoável nem racional. Não era razoável porque havia desequilibrio no uso do orçamento doméstico, e não era racional porque havia desequilibrio entre 'receita e despesa' orgânica. Enquanto a subalimentação quantitativa expunha o trabalhador pobre aos riscos de má nutrição nas diversas regiões do País, a subalimentação qualitativa era generalizada, igualando pobres e ricos pela ignorância.

Com relação a isso, Moscoso se aproximava dos demais autores, quando reiterava que o País dispunha de todos os alimentos úteis, só faltava educação. Se o desregramento era muitas vezes quantitativo, era constantemente qualitativo e provocava sempre a desnutrição. A flagrante subalimentação carencial das classes abastadas contrastava com as menos protegidas, vítimas da subalimentação global, como no trabalhador urbano e nas incultas populações rurais - era a miséria orgânica e absoluta. A alimentação do trabalhador era

${ }^{18}$ A Diretoria de Proteção à Maternidade e à Infância foi criada em 1935, pelo Decreto $\mathrm{n}^{2} 24.278$, de 22 de maio de 1934, com a extinção da Inspetoria de Higiene Infantil da Saúde Pública (BRASIL, 1935). 
pobre em calorias necessárias à tarefa cotidiana, pobre em proteína, vitaminas e minerais, portanto, inadequada ao clima e à profissão. $\mathrm{O}$ trabalhador comia pouco e mal - feijão, farinha, carne seca, acompanhados da cachaça - não tinha energia, não podia produzir, não tinha resistência, tornava-se doente, transformando-se em um peso morto para o Estado:

É o uso monótono e constante da farinha, do feijão, do arroz, às vezes da carne seca, com o abuso nocivo da cachaça. O trabalhador não usa legumes, não se utiliza de frutas, não toma leite e não come ovos, embora possa encontrá-los ao alcance, sem grande esforço, oferecidos pela uberdade do solo nacional a troco de um diminuto trabalho ou mesmo sem ele pela sua espontânea fertilidade. É o lastimável contraste entre a pujança da terra e o depauperamento orgânico do homem, conduzindo ao enfraquecimento da raça, resultantes da ignorância, da falta de educação e do descaso público na orientação de uma política alimentar para a solução do problema. (Moscoso, 1939:85)

A exemplo dos demais autores mencionados, Moscoso (1939) destacava que era a subalimentação qualitativa a forma mais grave, porque, sem caracterizar a fome, matava lentamente os seus descendentes. Nessa modalidade de alimentação

Alguns tinham abundância de proteínas - carne, peixe, ave, etc. -, esporadicamente; fartura de gorduras - banha, toucinho, carne de porco, lingüiça, etc.; mas sempre excesso de hidratos de carbono - batata, mandioca, farinha, massas, etc. -, com deficiência constante e quasi absoluta ausência de alimentos protetores, fornecedores de minerais indispensáveis e vitaminas necessárias - leite, ovos, manteiga, legumes e frutas. (Moscoso, 1939:84)

Era essa a flagrante subnutrição carencial das classes abastadas (como evidenciou Coutinho nos escolares do Rio de Janeiro), em contraste com as vítimas de subalimentação global (fome). Com isso, Moscoso (1939) demonstrava a tese assinalada pelos demais autores descritos de que a indolência e a falta de aptidão para o trabalho não tinham como causa o clima e a raça, mas a alimentação insuficiente.

Além disso, frisava também que eram esses graves e antigos defeitos que vinham influenciando sobre a raça e passando de geração a geração. Em sua essência, o mal provinha da monocultura da cana, imposta com um só intuito: aproveitar a vastidão do solo para a produção de açúcar, que garantia alto lucro nos mercados estrangeiros, deixando limitadas as alternativas alimentares que contribuiriam para a formação de hábitos mais saudáveis. Assim, a alimentação mantinha os traços característicos da cozinha afro-ameríndio-lusitana dos tempos coloniais, perdurando no brasileiro o modo de comer muito e errado ou pouco e também errado: 
É certo que o advento de outras culturas foi trazendo aos poucos modificações na alimentação, introduzindo o uso de outros produtos - batata, arroz, milho, carne -, sem, contudo, alterar a monotonia habitual e permitir melhor nutrição. Assim, continua e permanece ainda hoje a alimentação brasileira, como reminiscência dos tempos de colônia, de difícil e lenta modificação. Perdura o brasileiro neste modo de comer muito e errado ou pouco e também errado. (Moscoso, 1939:83)

No entanto, de acordo com ele, o operário nacional não tinha a mais rudimentar idéia sobre regras de boa alimentação, tampouco o Estado cuidava metódica e resolutamente de educá-lo, a fim de proporcionar-lhe a prática e os meios de adoção de uma alimentação conveniente. Quanto a isso, reiterou o enfoque que apontava a ignorância como o elemento fundamental (a despeito da ação da pobreza) que confinava todas as classes sociais, desde as mais pobres às mais abastadas, do citadino ao sertanejo, ao incrível desconhecimento dos rudimentares princípios de alimentação. A falta de educação alimentar implicava erros na organização do cardápio e distribuição das refeições.

A inconveniência do horário das refeições resultava da falta de ensino da boa alimentação, que também incapacitava as donas de casa no exato conhecimento da economia na aquisição, na conservação dos alimentos úteis e indispensáveis, na obtenção do melhor rendimento e no modo do seu preparo, com a preservação das substâncias neccessárias à nutrição (Moscoso, 1939).

Sob essa ótica, a indústria moderna facilitou o árduo encargo das donas de casa e contribuiu para modificar a alimentação, mas, ao mesmo tempo, proporcionou um grande número de produtos conservados que nem sempre guardavam suas vantagens nutritivas, garantindo lucros e vantagens apenas aos fabricantes. Além disso, a mecanização complexa, mas de fácil e leve manuseio, reduziu a capacidade de trabalho, exigindo menor robustez e estimulando a intromissão do sexo feminino nas fábricas, oficinas, laboratórios etc.

Com efeito, esse é um importante dado, visto que, segundo Carone (1975a), em 1912, por exemplo, dos 10.204 operários, de 31 fábricas têxteis de São Paulo, 67\% eram mulheres. Conforme indica Fausto (1976), as mulheres, em 1919, eram majoritárias na indústria têxtil no estado de São Paulo $(55,2 \%)$ e representavam significativa parcela no Distrito Federal (42,7\%). Ao mesmo tempo, constituíam maioria no ramo de vestuário e toucador, na Capital da República $(55,15 \%)$, e um contingente significativo, embora mais reduzido, no estado de São Paulo $(38,1 \%)$. Era certo que, para os homens, o trabalho feminino se transformava em ameaça de concorrência. Quanto a isso, numa assembléia da União dos Operários em Fábricas de Tecidos do Rio de Janeiro, em que se 
discutia a situação de uma fábrica onde os tecelões estavam sendo substituídos por mulheres, um operário se insurgia contra esse processo, aludindo que, em vez de ensinar o trabalho às mulheres, para logo em seguida substituí-los, deveriam fazer com que elas compreendessem que os seus lugares eram em casa, cumprindo o papel de educadoras daqueles que futuramente seriam os substitutos dos homens na luta pelo pão, pois o papel de uma mãe não consistia em abandonar seus filhos em casa e ir para a fábrica trabalhar, trazendo às vezes conseqüências irreparáveis, quando seria melhor que somente o homem produzisse, de forma a prover as necessidades do lar.

O trabalho à máquina, portanto, imprimiu mudanças nas atividades profissionais, refletindo nos hábitos alimentares. Esse processo alterou as exigências alimentares, configurando distintas formas de esforço físico, como promoveu o deslocamento dos trabalhadores, retendo uma pequena parcela na agricultura e encaminhando a maior parte para a indústria, o comércio, a burocracia e as profissões liberais (Moscoso, 1939).

A localização das indústrias em lugares afastados impôs grandes distâncias entre a residência do trabalhador e o local de trabalho. Conseqüentemente, desaparecia o hábito e a vantagem da alimentação em domicílio, que passava a ser feita no próprio estabelecimento ou calçadas adjacentes, com o recipiente malprovido e frio, ou tomada nos restaurantes próximos, onde a refeição era cara e, portanto, tinha que ser reduzida, mal-escolhida, além de malpreparada e malservida (Moscoso, 1939).

Além disso, a tentação da vida moderna era também um dos motivos da escassa ou imperfeita alimentação, visto que aguçava o desejo ou a exibição de conforto e prazer, dado pelos múltiplos objetos oferecidos à prestação, que desequilibravam os orçamentos domésticos, aumentando as despesas e reduzindo a quota destinada à alimentação. Quanto a isso, Moscoso (1939) reforçou que só a educação podia conduzir ao caminho certo da realidade. As variações de consumo dos diversos alimentos dependia do salário e sua utilização racional na parte destinada à alimentação. Para ele, as estatísticas feitas em vários países demonstravam que, à medida que a receita crescia, a despesa absoluta com a alimentação aumentava, mas a proporção destinada à alimentação diminuía. As residências mais confortáveis eram mais caras, diminuindo a proporção destinada à alimentação.

O número e a idade das pessoas da familia do trabalhador tinham grande influência na alimentação, visto que, quanto maior fosse a família, maior seria a despesa com a alimentação. Sendo a receita total a mesma e a despesa com as demais necessidades fixas, o único meio era reduzir a parte referente à 
alimentação, com grave prejuízo para a saúde. Essa situação era agravada se a família fosse composta de crianças que, obviamente, ainda não contribuíam para o aumento da receita total (Moscoso, 1939).

Para Fausto (1976), de modo geral, a visão do empresariado industrial brasileiro correspondia ao perfil traçado por Hobsbawm, quanto ao empregador inglês de meados do século XVIII. Os empresários achavam que a menor folha salarial como pagamento do maior número de horas se traduzia no mais baixo custo do trabalho por unidade de tempo. Antes da instituição do salário mínimo, "A remuneração da mão-de-obra era estipulada, dentro da conjuntura do mercado de trabalho, segundo os cálculos de cada empregador ou empregadores, de cada setor econômico, sem que, em todo o período, fosse estabelecido um salário mínimo por força da lei" (Carone, 1975a). De acordo com este autor, os salários se mantinham baixos no decorrer do tempo: segundo a categoria, um trabalhador em São Paulo, em 1886, ganhava a média de $2 \$$ a $4 \$ 000,{ }^{19} \mathrm{em}$ 1907, no Rio de Janeiro, 6\$000; em 1918, em São Paulo, entre 5\$ e 6\$000 e 3\$ a $5 \$ 000$ no Recife. Por isso, os dados indicados por Fausto (1976), para a indústria têxtil, não diferem muito dos anteriores, dado que, em 1919, o salário médio dos homens e mulheres no Distrito Federal era, respectivamente, $6 \$ 720$ e $5 \$ 165$ (mil réis por dia), e, em São Paulo, 5\$729 e 3\$738.

Assim, as condições de vida do operariado eram o reflexo do sistema de trabalho. Esse operariado se localizava sobretudo no Brás, Bexiga, Barra Funda, em São Paulo; Jaboatão e São José, no Recife; zona sul da cidade do Rio de Janeiro, os quais se constituíam em "antros fétidos que servem de habitação a milhares de famílias" (Carone 1975a:195). Os aluguéis eram caros, o custo de vida era alto, daí os salários serem insuficientes para o sustento da família, e ser necessário o trabalho de mulheres e crianças. Disso resultava, na visão do autor, a abundância de mão-de-obra facilmente manipulável pelos empregadores e à qual eram impostas condições de trabalho aflitivas nas fábricas, onde, sem condições higiênicas e de segurança, se propagavam doenças, ocorriam mutilações, às vezes mortes.

Além disso, o que talvez seja mais importante, a mecanização, conjugada com a disciplina, era a solução para a produtividade e, dessa maneira, a diferenciação de funções, como a necessidade de disciplina, impunha, no interior da indústria, uma nítida hierarquia social (Fausto, 1976).

${ }^{19}$ A unidade monetária herdada pelo Brasil de Portugal foi o mil-réis: Rs. $1 \$ 000(1.000 \$ 000=$ um conto de réis), substituído pelo cruzeiro, de igual valor, por força do Decreto-Lei n² 7.491, de 5 de outubro de 1942 (PRADO JúnIoR, 1978:anexos). 
Assim é que, para Moscoso (1939), outros múltiplos e complexos fatores econômico-sociais influíam sobre a alimentação do trabalhador - meios de transporte, produção, impostos, dificuldade de aquisição, preços de venda, oferta e procura, horas de funcionamento do comércio etc. Com isso, ele relativizava a tese da ignorância, advertindo que a garantia de uma adequada alimentação não estava somente no fato de como fazê-la, era também ter os meios de obtêla. Para ele, a melhoria da alimentação do trabalhador não seria conseguida simplesmente determinando-se o que devia comer e o modo de fazê-lo. O poder de aquisição aumentava com a elevação da receita ou com a baixa dos preços. Surgia, daí, o conflito entre o consumidor e o produtor, que tinham interesses contrários para a manutenção de um bom padrão de vida. Assim, o problema era de propaganda, mas era também econômico-social. A melhoria da alimentação do trabalhador só podia ser obtida com um conjunto de medidas tendentes à solução de várias questões do complexo problema.

Com Moscoso, chega-se a uma composição articulada e unitária na produção intelectual do período de 1934 a 1939, que foi a de analisar o processo formador dos hábitos alimentares e os defeitos deles decorrentes, muito mais nos limites de acesso aos alimentos impostos pela monocultura, que restringia o campo de opções geradoras de hábitos adequados, não obstante as diferenças evidenciadas no enfoque estabilidade/mudança. Isso sugere que, no campo da normatividade social, o indicador 'salário', que diferençava os pobres dos ricos, parecia se constituir em algo mais flexível, conjuntural, passível de ser minimizado por um ato pedagógico que possibilitaria a restauração do equilibrio no orçamento doméstico. Se isso é verdadeiro, adquiria maior significação na caracterização inicial do objeto da educação alimentar a ignorância, como categoria causal/ explicativa da subalimentação quantitativa (fome) e da subalimentação qualitativa. A ignorância se constituía como esfera de normatividade social, justificadora da má-formação de hábitos, igualando pobres e ricos, num país em formação e carente de recursos e, desse modo, embora os hábitos errôneos caracterizassem uma ordem estrutural, de mudança mais difícil do que o salário, podiam ser abolidos por uma ação pedagógica que devia não somente ensinar a comer, mas também a economizar.

Nesse nível explicativo, a formação e a persistência dos hábitos errôneos caracterizavam uma perspectiva dualista de estabilidade/mudança, em que o velho e o novo se configuravam polaridades no processo civilizatório brasileiro. Ao mostrar como os velhos hábitos alimentares do passado colonial eram atuais e permanentes na década de 30, os intelectuais, em sua maioria, delineavam uma história linear e contínua que não previa um terreno de rupturas no tempo 
sobre o modo brasileiro de se alimentar. Daí que, nessa tendência, não estava em questão o surgimento, em fins do século passado, de um parque urbanoindustrial que insistia em se consolidar na década de 30, com o Governo Vargas. Esse aspecto foi tratado muito mais como possíveis acréscimos (tentações da vida moderna) aos erros do passado, e menos como parte de uma história descontínua e contraditória do processo cultural civilizatório. Disso resulta então que, embora estivesse em questão a base cognitiva de pobres e ricos na relação com o alimento, o hábito alimentar, tal como foi concebido, acabava por traduzir muito mais uma relação de corporeidade entre essas classes, materializada no plano imediato da produção e do consumo, do que uma relação propriamente cultural, determinada historicamente no contexto de uma cultura global como amálgama dos diversos setores da vida social, no qual as classes se constituíam e afirmavam diversas e contraditórias visões de mundo.

Éverdade que o trabalho humano exige uma série de atos físicos, corpóreos, sem os quais o homem não conseguiria produzir um novo objeto com novas propriedades. Mesmo com a introdução da máquina, o homem não foi abdicado em sua materialidade, como sujeito da produção, mas revelado inequivocamente. Contudo, a materialidade corpórea humana não se reduz ao objeto de trabalho, mas no processo de transformação da natureza, a sua concretude se revela com a própria atividade subjetiva na produção de idéias, códigos e regras culturais e valores que modelam os usos e comportamentos corporais, hábitos e práticas que possibilitam individualizar uma dada classe social (Vásquez, 1990; Boltanski, 1989).

Nesse aspecto, para Da Matta (1991), o social e o cultural são instâncias diferentes, descartando a visão que considera os dois fenômenos como partes de una mesma coisa. A cada sociedade corresponde uma tradição cultural que se firma no tempo e se projeta no espaço, podendo ser reificada e, desse modo, a cultura sobrevive à sociedade que a atualiza num conjunto de práticas concretas. Assim, pode haver cultura sem sociedade, embora não possa existir sociedade sem cultura. Nessa perspectiva, o hábito alimentar, como um dos modos de expressão da cultura global, não se traduziria apenas por uma relação de corporeidade no âmbito das classes pobres e das classes abastadas, materializada no plano imediato da produção e do consumo, dado que é possível perguntar: como se constitui e se projeta no tempo a relação entre as classes sociais e o alimento, à luz da produção e instituição de idéias e códigos culturais no plano da arte de alimentar a vida (música, dança, pintura, artesanato etc.), da literatura, do sexo, dos rituais festivos e religiosos, dos diversos espaços de trabalho públicos e privados, dos meios de comunicação, dos espaços comerciais e de consumo coletivo, dos espaços de organização política etc., no âmbito rural e urbano? 
O urbano-industrial foi constituído por Costa (1938) e Moscoso (1939) como uma categoria descritiva no enfoque das modificações que as práticas alimentares sofreram no tempo, no âmbito das civilizações, na medida em que, ao caracterizar esse fenômeno também como um processo linear e contínuo, não levava em conta a especificidade das forças motrizes da sociedade brasileira e os dinamismos socioculturais nos quais o urbano-industrial era, em si, apenas um aspecto na formação e evolução das práticas alimentares.

À parte as diferenças na constituição da base cognitiva da educação alimentar, a verdade é que a conexão entre o biológico e o social foi operada por uma tendência majoritária de intelectuais que fizeram uso do método geográfico, tendo o inquérito alimentar como instrumento de investigação coletiva. Disso decorre que, no período de 1934 a 1939, o objeto e o conhecimento no processo de constituição da educação alimentar se aproximavam não apenas por uma dimensão de causalidade, mas só adquiriam significado em sua dimensão finalista, utilitária, consubstanciada num projeto de política alimentar para o Brasil.

\section{Educação alimentar e política alimentar: a caminho da racionalidade nacional}

A dimensão política do conhecimento sobre alimentação e nutrição, no período de 1934 a 1939, estava no reconhecimento, por parte dos intelectuais, de que o problema alimentar era uma questão de Estado. Nisso reside a explicação finalista pela qual é possível responder à questão: com que objetivo essa modalidade de conhecimento se produziu, ao tempo em que explicita os seus destinatários. Era por referência à configuração de um plano de política alimentar que a ciência da nutrição em formação adquiria feição instrumental na perspectiva da aplicação imediata e pragmática dos dados fisiológicos e de natureza social na solução do aspecto higiênico do problema: a determinação da alimentação racional nas várias regióes brasileiras a ser implementada pelo Estado.

No âmbito dessa produção intelectual, foi a partir do ano de 1937 que o conhecimento projetou tal objetivo. Para isso, Castro (1937), no livro A Alimentação Brasileira à Luz da Geografia Humana, tomou por base a ração alimentar média de 2.800 calorias, anteriormente constituída como padrão que satisfazia às necessidades do brasileiro, em toda a extensão nacional. Em todo o território, o homem médio necessitava de uma alimentação com as mesmas características desse padrão único que ele havia determinado. No entanto, tal uniformidade quanto ao potencial energético e a composição bioquímica desaparecia, ao construir a ração alimentar, pelo agrupamento racional das substâncias usadas como alimentos. Era nesse ponto que se impunha previamente 
um zoneamento do território, dividindo-o em várias regiões, correspondendo cada uma delas a um tipo de alimentação usual, e característico, pois o padrão racional deveria se aproximar do regime usual do povo. Assim, "Cada tipo corresponde a uma determinada região territorial, e representa o resultado da experiência humana, adaptando suas necessidades aos meios regionais de subsistência que o 'meio' apresenta com maior ou menor abundância" (Castro, 1937:149).

Desse modo, o autor dividiu o País em cinco regiões geográficas e construiu cinco regimes-padrão para uso nessas diversas regiões. Em sua crítica dos regimes propostos, ele alertava que não estava definindo um regime ótimo, e sim, mínimo. As condições econômicas do povo da zona I (Amazonas, Acre e Pará), por exemplo, e a produção local exígua de leite não permitiriam de nenhum modo um consumo médio mais elevado do que 250 gramas diárias desse alimento. Na zona II (Zona da Mata do Nordeste), o regime mantinha essa mesma quantidade de leite, sendo mais elevada a quantidade de albuminas (66\%), bem perto dos $70 \%$ desejados. Além disso, para essa zona, a taxa de frutas era o dobro da zona I, dada a sua maior riqueza natural. Já para a zona III (Zona do Sertão do Nordeste), onde havia escassez de carne, a quota de albuminas era preenchida com o milho, cujo valor biológico baixo era corrigido com uma quota de 500 gramas de leite, pois era intensa sua produção na região. Como as fontes naturais de legumes verdes eram escassas, nessa zona seca do sertão, a quota de legumes era menor nesse tipo de regime. Na zona IV (Zona do Centro), a quantidade de leite era maior do que nos três anteriores, seguida do milho, feijão e toucinho, alimentos habituais de Minas Gerais. Finalmente, para a zona V (Zona do Sul), era mantida a mesma taxa de leite e carne, substituindo o milho, e a farinha, pelo pão de trigo, o arroz e a batata. Castro (1937) explicava que não havia acrescido o trigo nos demais padrões dietéticos, primeiro, pelo fato de o trigo ser um produto de importação que drenava uma grande reserva econômica brasileira, devendo esse alimento ser substituído por similares nacionais, e, segundo, o trigo em forma de pão constituía um alimento caríssimo, racionalmente inacessível às possibilidades econômicas das classes pobres. Como a zona $\mathrm{V}$ era produtora de trigo, possibilitava a inclusão desse alimento no seu padrão dietético.

Com isso, fica evidente que o conhecimento produzido valia não apenas pela tentativa de aplicação de um método que individualizasse o campo científico em formação, mas também pelos resultados que de imediato pudesse apresentar. Era nesse aspecto que o novo paradigma em construção se diferençava dos estudos parciais e isolados de natureza ensaísta e literária. Se a fome e a subalimentação eram concebidas à luz do método geográfico como um fator de desequiliırio biossocial, a solução do problema estava com a ciência da nutrição, 
enquanto campo formador dos princípios de uma nova racionalidade que ajustaria as necessidades alimentares dos indivíduos às suas condições salariais $e$ às contingências da produção local, restaurando o equilibrio vital e social. Por essa ótica, ver-se-á que o conhecimento só podia ser canalizado para a configuração de uma política alimentar compensatória como mecanismo de adaptação e ajuste social para o qual a educação alimentar se configurava como instrumento de primeira grandeza, corrigindo os hábitos alimentares errôneos.

Castro (1937) considerava essencial o conhecimento do custo dos vários regimes, dado que tal conhecimento ressaltava na fixação dos salários mínimos (o salário mínimo já havia sido assegurado na Constituição de 1937), na determinação das quotas proporcionais das despesas familiares, no levantamento dos índices do custo de vida, na determinação dos salários nominais e reais etc. No entanto, os dados obtidos não permitiam o conhecimento completo das condições econômicas da alimentação em cada região, não sendo possivel fixar o custo de cada padrão alimentar. Assim,

Com tantas incógnitas, com tanta cousa por estudar, por saber, por pesquisar, não é possível apresentar-se, no momento, soluções definitivas ao problema alimentar brasileiro. O mais que se pode fazer honestamente, é apontar onde, ou melhor, por trás de que obstáculos se ocultam estas soluções. (Castro, 1937:165)

Quanto a isso, resguardadas as diferenças, os contornos da política alimentar foram delineados em torno dos seguintes eixos compartilhados:

- o Estado já acenava, em fins da década de 30, com especial atenção para o 'capital' assunto da alimentação, de interesse para a saúde e para a economia;

- no conjunto dos meios a serem adotados para a solução do problema alimentar, a educação alimentar era o premente e inadiável 'meio' mais prático e mais eficaz para iniciar a luta contra o apavorante flagelo da má alimentação; e

- a educação alimentar estava fundada nos seguintes objetivos: eugênico garantia a saúde perfeita, prevenia as doenças e dava robustez; social - reduzia a mortalidade, permitia maior procriação, prolongava a vida; e econômico assegurava a aptidão para o trabalho.

Tais postulados traziam em sua justificação três desdobramentos:

- no plano macrossocial, o fenômeno da alimentação estava diretamente vinculado à economia, incluindo-se aí o modo de produção de alimentos e o uso da terra, o preço dos alimentos, e o salário do trabalhador para adquirilos nas diversas regiões brasileiras;

- no plano microssocial, o equilibrio entre 'receita e despesa' orgânica, que mantinha a saúde do trabalhador e sua família, estava diretamente vinculado ao equilíbrio entre 'receita e despesa' no uso do orçamento doméstico, ambas as variáveis que deveriam ser atacadas pela Educação Alimentar; $e$ 
- ao Estado cabia viabilizar o conjunto de 'meios' para garantir o acesso do trabalhador aos alimentos, e ao trabalhador cabia aprender a comer e a economizar. A utilidade da educação alimentar estava na divulgação do valor dos alimentos para racionalizar o seu consumo de acordo com as exigências fisiológicas, ensinando a selecioná-los, conservá-los e prepará-los, com base em um cardápio racional que garantisse o uso racional do orçamento doméstico e corrigisse os erros e defeitos da alimentação.

De fato, a projeção pelos intelectuais de um plano de política alimentar com tais características a partir do ano de 1937 não se dava no vácuo, a considerar os acontecimentos políticos e culturais deflagrados no horizonte desse tempo histórico. O Estado Novo era caracterizado, por Vargas, de Estado Nacional. Os cinco primeiros anos desse regime corresponderam à progressiva, mas definitiva, consolidação do poder do Estado. Dessa forma, a maioria das reformas de natureza administrativa e política desse período dava continuidade àqueles que haviam sido apontadas em 1930. Uma vez tornado constitucional o estado de emergência, foram institucionalizados os instrumentos necessários para sua consecução: o Departamento de Informação e Propaganda (1939), o Código de Imprensa, publicado em dezembro de 1937, tornando ilegal qualquer referência desrespeitosa às autoridades públicas, e a Hora do Brasil, emissão radiofônica diária e obrigatória, por intermédio da qual eram divulgados os programas governamentais e as palavras do presidente. Além disso, uma das medidas de efeitos políticos imediatos foi a determinação da dissolução dos partidos políticos proibindo quaisquer símbolos, gestos e uniformes identificadores (Sola, 1990).

Como assinala Pecaut, quer se tratasse de 'organizar cientificamente' a sociedade ou de colocar o Estado a serviço da 'nacionalidade', os intelectuais da época fizeram-se porta-vozes de uma opinião já formada, colocando-se ao lado de agentes já construídos, procurando ocupar, com eles, uma posição de elite à margem das elites oligárquicas tradicionais, apostando no Estado:

O projeto do regime pretendia-se mais 'cultural' do que mobilizador, e a definição do 'cultural' confundia-se com a dos intelectuais. Tratava-se de construir o sentido de 'nacionalidade', de retornar às 'raízes do Brasil', de forjar uma 'unidade cultural'. Era sempre evidente, para os responsáveis pelo assunto no regime que 'cultura' e 'política' eram dois termos inseparáveis e que cabia a eles fundi-los no quadro do nacionalismo. (...) Assim, a cultura nacionalista oferecia um terreno de encontro entre os 'intelectuais do regime' e os outros. Além disso, não faltavam tentativas de aproximação dirigidas a estes últimos, visando a suscitar uma 'cultura de consenso', não no sentido de uma cultura para uso do povo mas sim de uma cultura das elites. Getúlio Vargas não foi o último a elogiar o fim dos homens 'letrados' satisfeitos com a sua torre de marfim, assim como dos homens de ação debruçados sobre as tarefas práticas. (Pecaut, 1990:69-70) 
Era nessa simbiose entre homens de pensamento e ação que os explicadores da situação alimentar dirigiam suas falas ào Estado, atribuindo ao conhecimento uma dimensão finalista centrada no esboço das linhas fundamentais da política alimentar, na qual a educação alimentar se constituía como instrumento dotado da maior eficácia. É certo que nem todos o intelectuais explicitaram com o mesmo rigor esta dimensão do conhecimento, mas deixavam transparecer um objetivo prático compartilhado que sinalizava nessa direção. Em maior ou menor grau, dirigiam as suas falas ao Estado. No processo de constituição da educação alimentar, a caracterização inicial do objeto, no período de 1934 a 1939, fornecia não apenas a base cognitiva desse campo, mas, ao mesmo tempo, indicava que tal base era necessariamente social, pois era somente nesse campo de normatividade que adquiria significado. Isso ficava bem evidente também nas palavras de Carmo (1937:153) quando afirmava que "uma política alimentar (...) haveria de ter suas bases, não nas pesquisas de laboratório, mas, principalmente, numa campanha de educação do povo". É digno de nota que, nesse processo, iam-se particularizando diferentes destinatários da ação educativa.

Nessa perspectiva, Coutinho (1937), no livro Valor Social da Alimentação, elegeu o escolar como destinatário sobre o qual a educação alimentar deveria exercer a sua função corretiva:

Seria aconselhável a creação de cursos dietéticos desde as classes primárias, cursos que bem orientados dariam às crianças um sentido real da alimentação $e$ dos seus verdadeiros valores. Desappareceriam muitos preconceitos alimentares, às vezes tão fortes, no que diz respeito à mistura de certos alimentos; também muita noção errada sobre nutrição. (Coutinho, 1937:334-335)

Em consonância com Coutinho, Costa (1938), no livro Bases da Alimentação Racional, também elegeu o escolar como destinatário da educação alimentar, visto que:

A nutrição, em muitos paizes, é uma das ciências aprendidas desde a escola primária. E agora repito novamente que devemos fazer tudo para que no Brasil também isto aconteça, afim de que as nossas crianças aprendendo, nas aulas de nutrição, os novos esclarecimentos desta ciência, possam não só formar o espírito no conhecimento das grandes verdades da alimentação, como também levar essas verdades às suas casas e dizê-las aos pais. Assim, em poucos anos todos saberiam, crianças e adultos, como fazer uma bôa alimentação. (Costa, 1938:96)

A diferença é que Coutinho (1937) se dirigia ao escolar das classes abastadas do Rio de Janeiro, e Costa (1938), ao escolar brasileiro teórico. Nisso residiam diferentes interpretações da realidade. Coutinho construiu os 'modelos dietéticos' a ser incorporados pelos escolares do Rio de Janeiro, pela educação 
alimentar, com os respectivos custos: 8 a 12 anos, 2.316 calorias, equivalente a $2 \$ 100$ mil-réis; 13 a 15 anos, 2.978 calorias, equivalente a $2 \$ 500$ mil-réis; e 16 a 17 anos, 3.502 calorias, equivalente a $2 \$ 800$ mil-réis. Costa extrapolou para o Brasil os resultados dos inquéritos levados a efeito, no Rio de Janeiro, que mostravam terem os escolares cariocas uma dieta insuficiente. Definia ele o escolar brasileiro como entidade abstrata, cujas necessidades alimentares variavam em razão da idade, chegando, assim, a um exemplo de menu (sem valor calórico definido) para um escolar de 8 a 12 anos que devia ser aceito como padrão. Tais autores comungavam, no entanto, das mesmas perspectivas. A alimentação do escolar interessava a todo o Brasil e já preocupava os homens mais esclarecidos, visto que, em 1935, já havia sido criada a Campanha Nacional pela Alimentação da Criança. No âmbito das medidas de puericultura, a higiene alimentar se apresentava como medida fundamental, na qual a educação alimentar já se configurava como instrumento pedagógico eficiente, pois:

A organização e marcha dos trabalhos, na Escola de Saúde ou nas classes de saúde, converge toda para um fim imediato: a saúde da criança; emprega sobretudo um instrumento, a higiene; e olha, mais longe, para um objetivo longínquo: a higiene da nossa gente, pela educação. Neste particular, a higiene alimentar está colocada em situação de relevo. Não basta dar de comer, é preciso ensinar a comer. É um enorme programa, cujo desenvolvimento levará benefício á população inteira. (Almeida Júnior, 1934:546)

Veloso (1940), ao reconstituir o percurso desse movimento de puericultura, assinalava que, comparando a situação do Brasil com a assistência à maternidade e à infância de outros países, como a Itália, a Alemanha, os Estados Unidos, a Argentina etc., pagava-se aqui o maior tributo em matéria de mortalidade infantil. Só no Rio de Janeiro, onde as obras assistenciais mais tinham-se desenvolvido, havia, naquela época, nada menos de 250 mil crianças a necessitar de amparo por parte do Estado. De um lado, a ignorância completa das mães; de outro, pobreza e miséria, determinando a falta de alimentos, principalmente leite, eram as principais causas da ruína do binômio mãe e filho, no Brasil. Nessas circunstâncias,

o nosso 'capital demográfico', o nosso capital humano, com expressão da própria economia nacional, se acham a um câmbio, a bem dizer, vil, indigno mesmo dos nossos fóros de povo civilisado, em doloroso e flagrante contraste com os progressos do século XX, 'século da eugenia, da medicina preventiva, dos exames periódicos de saúde, da higiene e, também, e sobretudo, da puericultura, com créches, lactários, pupileiras, escola-hospitais, clinicas escolares, preventórios, asilos, sanatórios, e colônia de férias para crianças' tudo isso que constituem hoje motivo de orgulho patriótico de dezenas de nações da terra. (Veloso, 1940:210) 
Veloso registrava que vinha afinal, em fins de 1937, o Estado Novo, e com ele a Constituição de 10 de novembro. O problema da assistência à infância passava a ser estudado cientificamente e defendido com excepcional sentido patriótico. Logo em seguida vinham as primeiras medidas asseguratórias do êxito do grande movimento libertador, a era da nova criança brasileira: criavase, na Universidade do Brasil, a cátedra de puericultura, confiada a Martagão Gesteira; lançava-se a pedra fundamental do Instituto Nacional de Puericultura, sob os auspícios do Ministério da Educação; preparava-se a primeira turma de puericultores, após rigoroso curso de aperfeiçoamento; e finalmente, coroando todas essas medidas, acabava de ser criado o Departamento Nacional da Criança:

Ao mesmo tempo, juizes, educadores, médicos, higienistas, pediatras, jornalistas, senhoras da nossa sociedade, num movimento, exaltadamente patriótico, transmitem a todas as camadas sociais do País - através do rádio, da imprensa, do livro, do cinema, da tribuna e da cátedra - a flama de entusiasmo e amôr à grande causa comum, ensinando a todos que o futuro da nossa querida Pátria, que a sua grandeza e progresso estão diretamente na dependência da nossa maternidade e da nossa infância. Cremos pois, no Estado Novo Brasileiro e nas intenções patrióticas e humanas de quem, nesta hora, o dirige - Getúlio Vargas. (Veloso, 1940:314)

Quanto a isso, a constatação evidenciada por Pecaut (1990:73) é sugestiva, quando assinala que:

O Estado e os intelectuais compartilhando o desdém pela representatividade democrática e a nostalgia por uma administração do social que tomasse o lugar da política, foram levados a agir como sócios a serviço da identidade nacional. Se os intelectuais aderiram a uma 'ideologia de Estado', o Estado aderiu a uma ideologia da cultura, que era também a ideologia de um 'governo intelectual'. Além disso, o Estado não conhecia outra expressão da opinião pública exceto a representada pelos intelectuais.

Segundo ele, o ensino representava um dos campos no qual foi mais sistemático o esforço do regime para criar a mentalidade do 'homem novo'. Como dizia Lourenço Filho (s/d), se a Revolução de 30 experimentou reforçar os laços da nacionalidade, não era por demais dizer que em 1937 esses laços se consolidavam. A Constituição de 1934 já consagrava o princípio da existência de 'diretrizes nacionais da educação'. A de 1937 reafirmou-o. A Comissão Nacional de Ensino Primário, para o estudo das questões básicas de sua organização, orientação e articulação em todo o País, veio definir uma política que, sem demora, devia ser executada:

Não será de admirar, que só desde então se tivesse reconhecido ao Estado, de modo claro, a prerrogativa de educar, e que as organizações políticas cuidassem da educação popular, intensa e extensamente. A educação não 
deve ser vista como direito ou dever do Estado: é uma função natural, um processo de vida para a coordenação e defesa da Nação que êle representa. (Lourenço Filho, s/d:104)

Assim, a considerar as obras de Coutinho (1937) e Costa (1938), fica visível que eles não delimitaram um plano de política de alimentação escolar, mas sinalizavam para o Estado, e quem mais se interessasse, os defeitos da alimentação, e que somente a educação alimentar se constituía no meio mais eficaz de correção, instituindo uma nova racionalidade. Nesse aspecto, Costa (1938) destacava que só a boa alimentação dava aos povos os claros e largos destinos. Para ele, a resolução do problema da alimentação popular, entre a população brasileira, devia ser a maior preocupação dos homens de ação pública, e repetia o que tinha afirmado em outras publicações: a necessidade de serem incluídos cursos de alimentação no currículo das escolas primárias. A criança que aprendia a se alimentar certo, que formava o seu espírito encarando com seriedade os problemas alimentares, na sua expressão social e individual, seria um adulto sempre atento a essa questão e já iria trabalhando, mesmo durante a infância, para os melhores destinos do País, pela influência sadia e pelos conselhos úteis que levaria, da escola, ao espírito dos pais. No entanto, os médicos deviam ser aparelhados dos métodos de pesquisa que assegurassem um rendimento maior aos seus estudos. A criação de um Instituto Nacional de Alimentação, com filiais nas diversas zonas do vasto território brasileiro, deveria, para ele, ser incluída entre as medidas a se tomar no País. Então seria feito o estudo das condições de deficiência alimentar do povo local, a pesquisa do valor nutritivo dos alimentos daqui, a organização das dietas adequadas e a assistência alimentar, direta e gratuita, às classes pobres.

Diferentemente de Coutinho e Costa, Mendonça (1938), no livro Noções Práticas de Alimentação, elegia o adulto como destinatário dos princípios gerais de higiene dietética e corporal (trabalhador em atividade leve, trabalhador braçal, e os desportistas e soldados), a serem veiculados pela educação alimentar. No entanto, ele não esteve empenhado, como Castro (1937), em determinar o padrão dietético regional desses trabalhadores, mas, apenas a título de demonstração, caracterizou a alimentação habitual de quatro regiões brasileiras, de onde se deduz que a ração alimentar racional (média) anteriormente construída podia ser estendida a todas as regiões para um adulto teórico. Aliás, a esse respeito, Castro já havia argumentado que o padrão dietético médio teoricamente definido, à luz da fisiologia, satisfazia as necessidades do homem brasileiro em toda a extensão nacional. Tal uniformidade só desapareceria ao construir a ração alimentar pelo agrupamento racional dos alimentos locais. Significa dizer que as diferenças e a concreticidade do homem brasileiro estavam nas características 
do meio social em que se situavam e não nas suas características e necessidades biológicas. Estender ao nacional a ração alimentar média fundada num escolar (Costa, 1938), ou num homem teórico médio (Mendonça, 1938), era uniformizar muito mais as diferenças sociais e econômicas que, em última instância, determinavam o acesso aos alimentos preconizados do que as diferenças biológicas, dado que o padrão racional era estimado pela média dos atributos físicos e necessidades médias dos grupos populacionais.

Assim, Mendonça (1938) definia os princípios gerais e específicos da higiene alimentar a serem veiculados pela educação. Entre outros:

I. Fazer boa mastigação. A refeição bem mastigada e feita lentamente, soffre melhor digestão, porque sendo bem triturada, melhor se submette aos succos digestivos (...).

II. Evitar os líquidos durante as refeições. A água e as bebidas tomadas durante as refeições, diluindo o succo gástrico, enfraquecem e difficultam o acto da digestão no estômago.

III. Fazer pequeno repouso após as grandes refeições, não só corporal, como também intelectual. O esforço intellectual reduz a irrigação sanguínea ao nivel do apparelho digestivo e retardam a digestão.

IV. Fazer três a quatro refeições ao dia, com intervallo mínimo de 4 horas.

$V$. Evitar as refeições demasiadas e os pratos muito condimentados, que são de diffícil digestão.

VI. A quantidade da alimentação, isto é, o valôr calorico total, é indicado conforme as condições de vida. (Mendonça, 1938:79)

Para os desportistas e soldados:

I. A alimentação deve ser predominantemente mas não absolutamente vegetariana nos dias que precedem a prova desportiva ou a campanha militar. Esta alimentação defende o organismo contra acidose e portanto contra a fadiga e o desanimo, porque augmenta os valores alcalis dos humores.

II. A alimentação vegetariana deve ser rica em substâncias crúas, saladas, verduras e fructas.

III. Os alimentos de origem animal devem ser principalmente o leite e o ovo, sendo reduzida a quantidade de carne.

IV. Com o fim de evitar a retenção líquida, deve ser reduzida a quantidade de sal.

$V$. Serão abolidas as bebidas alcoólicas e o fumo.

VI. Serão evitados os excessos sexuais.

VII. Somno sufficiente e distrações moderadas.

VIII. Funcção intestinal regulada pela alimentação e sem medicamentos. (Mendonça, 1938:86-87)

Como será visto, a educação alimentar ia-se configurando na interface da higiene alimentar, na perspectiva de uma intervenção preventiva de tudo o 
que pudesse impedir o livre desenvolvimento das capacidades vitais na criança, necessárias ao aperfeiçoamento eugênico da raça, bem como da restauração das capacidades produtivas do adulto.

Quanto a isso, embora Botelho (1938), no livro Os Pequenos Fundamentos da Bôa Alimentação, não tenha também delineado um plano de política alimentar, afirmava que, no Brasil, havia necessidade urgente de inaugurar essa política, por dois motivos: o primeiro era que a maior fonte de riqueza do País era o alimento. Estava-se em plena fase agropecuária. Tinha-se, pois, e de fácil aquisição, o alimento. Regular a sua distribuição nacionalmente era um problema a ser resolvido, dando a uns estados o que faltava, inversamente ao que em outros existia em abundância. O segundo motivo resultava por um contraste do primeiro. A despeito dessa grande produção de alimentos, num país em que carne, leite, ovos, cereais, legumes e frutas existiam, a população, mesmo a minoria rica, comia mal. Com Botelho, a educação alimentar começava a adquirir um caráter de universalidade, na medida em que ele indicava os lineamentos gerais de uma campanha universal que julgava devia ser feita:

I. Creação de refeitórios municipais ou cosinhas ambulantes que atendessem, em particular, às merendas escolares racionais;

II. Creação de cooperativas alimentáres nas coletividades (escolas, fábricas), de que resultasse o embaratecimento dos gêneros essênciais ou das rações racionais;

III. Creação de cosinhas experimentais de que resultasse o emprêgo economico de nossos numerosos produtos ainda não utilizados;

IV. Criação de cursos, para senhoras, de economia alimentar doméstica;

$V$. Ensino da alimentação racional ao povo, sob fórma de verdadeira campanha, pelas suas cátedras que eram o jornal, os cartazes, o rádio e o cinema;

VI. Ensino das noções elementares de nutrição nas escolas primárias e secundárias.

VII. Ensino nas faculdades de Medicina, em cadeira especialisada, da 'Ciência da Nutrição';

VIII. Órgãos de governo que regulassem a distribuição dos alimentos essenciais e facilitassem seu barateamento, em prejuízo economico de outros alimentos de luxo ou dispensáveis;

IX. Órgãos de governo que fiscalisassem as rações em instituições coletivas particulares (sobretudo nos internatos de colégios);

$X$. Órgãos de governo que estudassem racionalmente a questão do salário mínimo, levando em conta o meio ambiente e o número de pessoas da família. (Botelho, 1938:8-9)

Nesse aspecto, o autor alertava que em um país de pequena fortuna, como o Brasil, as soluções propostas tinham que ser retardadas, em parte, pelas questões 
econômicas. No entanto, considerando o critério científico com que tais propostas foram preconizadas, a relação custo-benefício seria alta, resultando na melhoria do capital-homem. Nesse caso, vale registrar que, a exemplo de Mendonça, Botelho (1938) estendia a ração média ao território nacional, procedendo à divisão do País em diversas regiões apenas a título de caracterização do regime habitual.

Diferentemente de Coutinho e Costa, que elegeram o escolar como destinatário da ação educativa, e Mendonça, que elegeu o adulto trabalhador, Carmo (1937) ampliava as idéias de Botelho, apresentando um plano de política alimentar abrangente e universal para o País, no qual requisitava a intervenção do Estado na alimentação do povo, ao tempo em que sugeria a criação de instituições para isso. Visava responder à questão: "Qual o plano mais eficiente de uma campanha de vulgarização de melhores normas alimentares para o povo brasileiro?" Na mesma trilha de Castro, ele delimitou, de fato, as zonas climáticas do País, a geografia botânica, a densidade demográfica e a geografia econômica, pela qual traçava o mapa agronômico, de modo a caracterizar as diferentes regiões de produção alimentar, bem como a sua relação com a população de 40 milhões de habitantes. Era nesse meio que se situava o homem brasileiro com seus diversos gêneros de vida e recursos alimentares.

Os recursos econômicos diziam respeito às características da produção de alimentos básicos, à pecuária e à pesca. Nesse aspecto, foi Carmo (1937) quem expôs um mapa agronômico consignado em cinco zonas climáticas do País. No entanto, considerava mais acertado, para os fins da política alimentar, o zoneamento baseado na tradição comercial e em outros recursos de ordem econômica. Com base no que indicava o Órgão de Estatística da Produção, do Ministério da Agricultura, tal zoneamento ficou reduzido a cinco grupos, cuja superfície e população o autor teve o cuidado de calcular: Região Norte-Acre, Amazonas, Pará, Maranhão, Piauí, com uma superfície de $3.928 .789 \mathrm{~km}^{2}$ e população de 3.736.104 habitantes; Nordeste - Ceará, Rio Grande do Norte, Paraíba, Pernambuco e Alagoas, com superfície de $765.535 \mathrm{~km}^{2}$ e população de 9.131.213 habitantes; Região Este - Sergipe, Baía e Espírito Santo, com superfície de 595.615 km² e população de 6.149.345 habitantes; Região Sul - Rio de Janeiro, São Paulo, Paraná, Santa Catarina e Rio Grande do Sul, com superfície de 765.994 km² e população de 16.869.620 habitantes; e Região Centro Minas, Goiás e Mato Grosso, com superfície de $2.731 .044 \mathrm{~km}^{2}$ e população de 9.908.682 habitantes. Em todos os estados eram produzidos: a banana, para consumo normal, cuja estimativa para o ano de 1936 era de 71.745 cachos; a mandioca, amplamente usada na alimentação, que ocupava uma área de 350 mil hectares, com uma produção média de 17 milhões de sacas; o abacaxi, com 
uma produção de 82 milhões de frutos; a uva, com uma produção média anual de 230 milhões de quilos; o trigo, com produção estimada, em 1935, de 143 milhões de quilos, sendo o Rio Grande do Sul o maior produtor; a aveia, com uma produção, em 1933, de 114 mil quintais, incluindo o Paraná, Santa Catarina e Rio Grande do Sul. Pela sua extensão, não estão aqui apresentados os dados fornecidos por Carmo referentes à exportação e à industrialização desses alimentos.

Nessa abordagem, a pecuária era uma das riquezas mais promissoras, pela vastidão do território e pela ausência de regiões propriamente improdutivas. No Rio Grande do Sul, a pecuária era calculada em 123 milhões de bovinos, sendo que São Paulo, Minas, Goiás e Mato Grosso somavam 26 milhões. Assim:

Far-se urgente a intensificação da industria do frio, com localização de frigorificos em toda parte, afim de que toda nossa população possa se alimentar de carne, evitando-se assim, a carencia proteinica que se observa no interior, causa eficiente de debilitação da raça e do aumento da mortalidade por tuberculose. (Carmo, 1937:51)

Ainda de acordo com esse autor, o Nordeste, para maior aproveitamento agrícola, necessitava instalar, em todos os recantos, os campos permanentes de produção, fazer o aproveitamento racional das águas para irrigação da lavoura, intensificar a penetração do interior por estradas, educar o povo para o trabalho, garantir a propriedade e sanear a zona rural, que abrigava na época $10 \%$ da população brasileira, com quatro milhões de habitantes.

Coincidentemente, o peixe era destacado como alimento agradável, bastante nutritivo e de fácil digestão. Como resultado de longo contato com os pescadores, percorrendo as praias do Distrito Federal e do estado do Rio para lhes prestar assistência médica, Carmo (1937) resumia em oito itens a sua colaboração ao Primeiro Congresso Nacional de Pesca (1934), sugerindo melhorias para a instrução e educação daqueles homens do mar e suas famílias:

$1^{\circ}$. As escolas para pescadores ficarão subordinadas a um programa comum de ensino;

$2^{\circ}$. O professorado deverá ser instruido, especialmente nas novas normas de educação;

$3^{\circ}$. O material escolar será devidamente padronizado e uniforme, capaz de garantir a unidade de ensino em todas as colonias e capatazias;

$4^{\circ}$. Será instituída uma direção central, de modo a imprimir ao ensino, normas técnicas capazes de modificar o habitat dos pescadores;

$5^{\circ}$. Os pescadores serão congregados em centros de interesses: Circulos de pais e mestres, gremios esportivos e literarios, grupos de escoteiros, afim de afastálos do ambiente do vicio (jogos, bebedeiras, fumo, desperdicios...) que deprime e concorre para a contaminação dos escolares pelo mau exemplo; 
$6^{\circ}$. A escola deve ficar ligada ao médico, quer pela inspeção escolar, quer pela inspeçāo sanitária;

$7^{\circ}$. Dada a grande massa de analfabetos adultos, o ensino se processará tambem para adultos, sendo que na escola, pelos meios persuasivos e indiretos, orientar-se-ão os escolares no sentido de transmitirem aos seus genitores e parentes os novos hábitos de educação de economia e trabalho que fossem adquirindo na escola;

$8^{\circ}$. Serão seccionados livros ou aberto concurso para escolha de compêndios escriptos na linguagem dos pescadores e conteúdos, entremeados, com assuntos de pesca, ou da vida do mar, e correlativos, novas matérias capazes de modificar a orientação unilateral dos habitantes praianos, proporcionando-lhe oportunidades para melhorar a sua profissão ou de se distinguirem em novas atividades (escolas vocacionais). (Carmo, 1937:58)

Segundo Carmo (1937), havia um grande número de subalimentados, para os quais haveria de ser praticada a alimentação em massa a título terapêutico, como medicina de urgência. Nessas condições, tal questão tinha caráter de medicina social, da alçada da higiene pública, merecendo os mesmos esforços que se desenvolviam contra as epidemias e para o melhoramento das condições mesológicas pelo saneamento. Indagando as razões da subalimentação, via espelharem-se nesse fenômeno os defeitos de organização social, próprios e justificáveis em país de formação pobre, onde todas as iniciativas ou melhoramentos introduzidos oneravam o erário com empréstimos, concessões ou operações de crédito. Nisto, ele podia afirmar que a principal causa da subalimentação, que acarretava por sua vez a subnutrição, numa correlação lógica de causa e efeito, era de fundo econômico, afetando, assim, uma grave questão de sociologia e de economia política. Quanto a isso, Carmo (1937) perguntava: "E o salário mínimo nestas regiões?". As estatísticas ainda não forneciam tal resposta, e somente podia afirmar, pela tradição oral, pelas observações in loco, que o salário era baixo, por vezes miserável. O trabalho em qualquer de suas modalidades não era remunerador à altura de um salário eqüitativo, capaz de assegurar a subsistência. O custo de vida aumentava em progressão geométrica, enquanto os salários o faziam em progressão aritmética.

Para Carmo (1937), era hábito acusar-se como responsável da má alimentação a pobreza e a ignorância. Não restava a menor dúvida. Era um truísmo refutável, apenas não era a causa, mas o efeito. Segundo ele, era possível considerar ainda os dois fatores - pobreza e ignorância - separadamente. Havia famílias abastadas, porém ignorantes, incapazes de estabelecer um padrão de vida, inteiramente desorganizadas pelo desperdício. Em outros casos, inúmeros eram os lares pobres que se arranjavam com relativa facilidade, dentro de uma economia doméstica invejável, aproveitando as mínimas coisas, sujeitando-se a um orçamento rigoroso e privando-se de superficialidades. 
Esse raciocínio encaminhava para uma orientação de economia, norteada por um plano educacional. Conhecido o fator econômico, por conta do qual corria firmemente o baixo padrão da vida nacional, e feita a dissociação dos elementos pobreza e ignorância, que tanto podiam coexistir, como agir separadamente, seria fácil encarar o problema alimentar por um prisma estritamente pedagógico. Com isso, Carmo (1937) afirmava que teria de emprestar ao termo educação uma significação bem ampla, como fazia Miguel Couto: educação doméstica, educação econômica, educação sanitária, 'educação alimentar'. Nessas condições, poder-se-ia admitir o problema como da alçada educacional e pensar um plano pedagógico, vazado em uma campanha generalizada e uniforme, a ser desenvolvida em todo o território nacional. Estabelecidos os padrões alimentares médios, era necessário coordenar esforços para a aplicação prática desses elementos, e nisto residia, forçosamente, o ponto vital do assunto, pois não era tarefa simples ensinar milhões de pessoas a comer. Era necessário convocar um grupo de homens de boa vontade, para levantar cientificamente a bandeira da alimentação sadia e penetrar todos os recantos do País. No entanto, não transparecesse desse pensamento a idéia de que tão grande programa pudesse ser realizado sem o auxilio indispensável do governo. Não. O plano requeria apenas liberdade de ação, desapego das barreiras burocráticas. Para Carmo (1937), a parte puramente oficial do governo devia ser a da criação do Instituto de Nutrição, órgão autônomo e centralizador de estudos e pesquisas (administrativamente nos moldes do antigo Instituto Oswaldo Cruz), e do Comitê de Alimentação, destinado a regular o que ele chamava de 'preço da vida'.

Esse Comitê Técnico de Alimentação, sob a égide do Ministério do Trabalho, Comércio e Indústria, seria criado com o fim de fazer a racionalização dos três elementos - produção, distribuição e consumo -, tratando precipuamente de:

1. (Publicação de monografias simples, sobre a produção de generos alimenticios, seu logar de produção mais eficiente, fabricação ou transformação. Estatistica da produção: importação, exportação e consumo.

2. (Instruções periódicas pelos meios de difusão sobre o movimento de preços, sobre a produção (colheita e curso de certos produtos).

3. (Instruções e referências sobre a legislação relativa ao comercio de alimentação.

4. Estudo sobre os transportes de generos de primeira necessidade: novas adaptações higiênicas e rápidas, com o aproveitamento dos modernos conhecimentos, da industria de frios.

5. (Documentação de interesse do comércio de gêneros alimenticios. Todo este material teria de ser padronizado, de modo uniforme, calcado nos seguintes dados, indispensáveis: 1 - Produção dos 'stocks'; 2 - Entradas e saidas; 3 Aprovisionamento visivel e invisivel; 4 - Consumo. (Carmo, 1937:135) 
Porém, Carmo (1937:136) aconselhava a considerar, no problema alimentar, uma parte econômica referente não só à questão dos salários, mas também à do custo de vida, pois era esse, sem dúvida, um fator de grande importância, a que se prendia até a paz interna de uma nação, haja vista como "indivíduos exploradores da demagogia encontram nisto um apoio forte para desorientar as populações. Uma politica social faz-se igualmente necessária guiando o povo e educando". Além disso,

intervenção do governo não quer dizer entrave à ação da iniciativa privada, mas sim orientação racional e uniforme, facilitando aos produtores e distribuidores, os instrumentos de racionalização e normalização dos produtos e de suas trocas, afastando inúteis concorrências e tirando toda oportunidade a intermediários e agiotas. A normalização das embalagens de venda em grosso; com um frete favorável e a adoção de embalagem especial para o consumidor, evitar sobretaxas, eis providências de grande repercussão no barateamento dos produtos. (Carmo, 1937:137)

A exemplo do deputado Hirmino J. Quirós, que havia apresentado na Argentina um projeto de 'organização grangeária', o autor recomendava que tal medida tinha inteiro cabimento no País, pois era sabido que a criação de aves e a horticultura eram incipientes aqui, e longe estava de poder alcançar as necessidades de consumo locais. Os inquéritos feitos sobre alimentação tinham demonstrado que todo o produto do interior era exportado para as cidades, privando os moradores locais desses elementos imprescindíveis à sua alimentação.

Nessa perspectiva, o governo brasileiro, ao fazer a entrega dessas terras, procederia previamente ao estudo agronômico para a determinação categórica de sua aptidão para a cultura agrícola, e organização das 'colônias grangeárias'. Com o fim de estimular o trabalho e dar oportunidade a grande número de colonos, Carmo (1937) sugeria a limitação da extensão das terras, às quais não poderiam ser menores que 2.500 hectares, nem maiores que dez mil. Essas terras seriam preferentemente as do Estado, podendo o governo, em casos especiais, fazer desapropriações por utilidade pública. Um programa de proteção eficiente ao trabalhador rural e à propriedade agrícola rural poderia ser resumido nestas providências:

1. Uma politica de reerguimento da propriedade rural, pelo saneamento e adoção de maquinas agrárias modernas e o conhecimento da agricultura cientifica, para maior rendimento da produção e trabalho menos penoso;

$2^{\circ}$. Desenvolvimento do crédito agricola;

$3^{\circ}$. Construção de casas com conforto para fixar o trabalhador á terra, educandoo superiormente pela ambição da posse de uma propriedade e da vida em comum, nas sociedades rurais; 
$4^{\circ}$. Extensão das leis sociais ao trabalhador rural;

5०. Introdução de conforto: eletricidade, captação de água potável, desenvolvimento das comunicações;

6. Creação de obras sociais educativas e de recreação: cinema, (fitas agricolas), escolas, Centros de Pais e Mestres, grupos de escoteiros, campos de jogos, música, Foot-ball. (...) É esta a politica que nos compete seguir em relação aos nossos latifundios: descubramos, nós mesmos, o nosso querido Brasil! Não será necessario sair do Rio de Janeiro, para se encontrar amostra de sertão, com as mesmas caracteristicas dos logarejos mais afastados. Na Zona rural da Capitál da Republica a mortalidade geral é de 23 por mil e a infantil atinge 300 por mil! (Carmo, 1937:139)

Nessa viagem à área rural na perspectiva da criação do Comitê Técnico de Alimentação, Carmo reiterava que insistia em dizer que o consumo comandava a produção e esta era a chave que orientava e dirigia o standard de vida de uma nação. Quanto a isso, "A educação do consumidor, avisando do valor dos alimentos e as equivalências nutritivas de certos gêneros que têm sucedâneos mais baratos, evita o luxo e facilita o governo estabelecer a pauta dos gêneros verdadeiramente populares para a proteção fiscal" (Carmo, 1937:137).

Nessa perspectiva de universalidade, dirigia o autor também sua fala aos patrões, apontando "novos hábitos para empregadores e empregados". No âmbito das indústrias, já bem firmadas no País, podendo-se mesmo dizer que esta começava a ser uma nação industrial, o que parecia mais aconselhável, nas palavras de Carmo (1937), paralelamente ao incentivo de novas fontes de trabalho, era o aperfeiçoamento dos hábitos internos dos trabalhadores. Os industriais, indo ao encontro dos seus trabalhadores, atendendo a suas necessidades, proporcionando-lhes conforto e abrindo a todos eles horizontes novos, por uma inteligente campanha educativa de bons hábitos, estariam fazendo obra de proteção ao seu próprio capital, pois assegurariam, forçosamente, um maior rendimento nas atividades dos seus estabelecimentos. Desse modo, Carmo recomendava a ração padrão média de 3 mil calorias, indicada pela Sociedade das Nações, para o homem médio em atividade moderada. Segundo ele, a comissão de salário mínimo, depois de estudar as várias condições do País, estabeleceu uma tabela de ração para o operário que servia de base para dimensionar o problema. Essa comissão havia calculado um total de 3.888 calorias, que ele considerava um valor elevado, salvo em casos de indicação para trabalho forçado, em clima penoso.

Nessa fala aos patrões, Carmo argumentava que era a estatística que ensinava quanto tinha melhorado e barateado a mão-de-obra depois que, ao lado de outras vantagens, foi instituída a assistência médica nas fábricas. Isso 
tendia a se ampliar se todo estabelecimento possuísse seu restaurante para fornecer alimentação sadia aos trabalhadores pelo preço de custo, ou pelo menos ter um refeitório condigno, onde os mesmos tomassem as refeições, pondo termo ao detestável costume de fazê-las nas calçadas, no interior das oficinas e nos recantos, sobre folhas de jornal, ao desabrigo do mais rudimentar preceito de higiene e de decência.

Nesse enfoque, em que não fosse possível a instalação anteriormente preconizada, outra forma interessante seria a adoção de restaurantes ambulantes que se postariam à frente dos estabelecimentos ou dos núcleos de trabalhadores, às horas das refeições, os quais seriam devidamente fiscalizados, tanto quanto à higiene como em relação à ração alimentar e tabelamento dos preços. Essa prática já era feita em vários países, como nos Estados Unidos, Alemanha, na Argentina, sob o influxo das idéias do prof. Escudero, onde os restaurantes eram mantidos pela municipalidade. No Distrito Federal, a Prefeitura Municipal, pelo seu Departamento de Abastecimento, teria ótima oportunidade de seguir esse exemplo de proteção ao trabalhador, tirando-o de uma situação de inferioridade. Nesse aspecto, Carmo (1937) exemplificava que o Laboratório do dr. Paulo Seabra, tanto no que concernia à alimentação, como na administração em geral, era um modelo para a indústria particular e um exemplo para as organizações públicas. Podia perfeitamente servir de padrão nos casos de obrigatoriedade de restaurante nos estabelecimentos industriais.

Tratava-se do Instituto Orlando Rangel que, sob a direção do dr. Paulo Seabra, possuía um refeitório modelar, com capacidade para 100 a 120 pessoas. Aí fazia refeições, ao mesmo tempo, todo o pessoal do estabelecimento. A cozinha era perfeita; tinha os seus utensílios esterilizados, dentro do maior asseio. Tais refeições saíam a preço de custo, numa média, de 900 réis a mil réis e eram adquiridas pelo processo de cooperação. Terminada a refeição, o refeitório conservava-se perfeitamente limpo, dando admirável impressão de ordem e decência. O pessoal alegre e bem satisfeito trabalhava com acentuado espírito de cooperação e respeito. Em contraposição à pequena distância do laboratório do dr. Seabra, havia uma fábrica de tecidos instalada há mais de 30 anos, dando trabalho a dois mil e tantos trabalhadores. Infelizmente, aí, o espetáculo era chocante, as pessoas na hora da refeição exibiam um arsenal miserável de latas velhas e marmitas sujas, na qual carregavam as refeições e comiam, espetacularmente, nas sarjetas, como desumanos.

Nessa política universal, Carmo (1937) assinalava que deviam ser aproveitados, em todos os sentidos, os meios pedagógicos para ensinar o brasileiro a comer e a economizar, isto é, a saber empregar com acerto o seu orçamento na aquisição de gêneros alimentícios e na obtenção de conforto 
para o seu lar. Um dos recursos pedagógicos por ele preconizados era a criação do Salão de Alimentação, no âmbito de uma Feira de Amostras que se realizava no Distrito Federal.

Para o autor, a Feira de Amostras, além de sua função de propaganda de toda ordem, era um excelente instrumento educativo, de fácil utilização, devido ao grande número de pessoas que por ali transitavam, com marcante espírito de curiosidade e observação. Toda propaganda que tinha lugar no seu recinto eram aulas animadas e vivas, de escola ativa, que o grande público freqüentador recebia de ânimo prazeroso e até pagava para isso. Nos Estados Unidos, na França, na Alemanha e em grande número de outros países, os museus tinham seções especializadas que se destinavam ao ensinamento dos preceitos da alimentação popular. Assim:

Todos os nutricionistas que têm empreendido viagens de estudos, voltam encantados pelo sucésso obtido nos varios paizes, por meio de exposições permanentes de alimentaçāo, ás quais concorrem comerciantes e industrias de generos alimenticios, as escolas de veterinaria, os departamentos de agricultura $e$ industrias animais, lacticineos, e produtos de pesca, as padarias, as fábricas de massas alimenticias, em suma tudo que diz respeito com a alimentação. (Carmo, 1937:158)

Eram verdadeiros salões de alimentação divididos em seções, demonstrando o valor dos alimentos, sua aplicação higiênica e econômica, e pondo em evidência os inconvenientes de uma alimentação imperfeita, com a organização de cartazes bem expressivos e as preleções de caráter popular, ficando completa a inteligência desses programas, essencialmente para o povo (Carmo, 1937).

Para isso, as autoridades federais e municipais, bem como as instituições em geral e todos os interessados pelas questões de nutrição, deveriam aproveitar a Feira de Amostras, tão popular no Rio de Janeiro naqueles anos, para instalar o Salão de Alimentação de 1937. Acontecimento inédito por aqui, essa Feira teria a grande virtude de poder expor os produtos alimentares locais, com um cunho prático e educacional, sem quebrar, contudo, com as finalidades comerciais do evento. Durante uma quinzena poder-se-ia manter um curso repetido de economia doméstica e de alimentação popular, dedicando cada dia a um alimento básico da economia brasileira: dia da carne, dia do pescado, dia do leite, dia das frutas, dos cereais, do pão etc.

A objetivação desses cursos seria feita em pequenos banquetes para os pobres, cujo cardápio teria de ser escolhido de acordo com os salários triviais e a média de cinco pessoas da família que era, mais ou menos, o padrão local. As refeições deveriam ser calculadas em relação às necessidades calóricas de cada 
pessoa da família, sua ocupação, idade, clima, estação e demais variantes. Nestas refeições, a bem dizer, padronizadas, seria defendido o consumo proporcional de verduras, frutas e laticínios, exaltando-se o valor das vitaminas, da carne e cereais, procurando-se ainda tornar familiares as noções de caloria, proteínas, hidratos de carbono e sais minerais. Em tudo deveria ser o problema apresentado no seu tríplice aspecto: educacional, social e econômico. É digno de nota que Carmo (1937) tinha uma grande passagem nos meios culturais mais amplos, pois, como ele ressaltava, essa matéria havia sido publicada no Diário Carioca, sendo concluída com a seguinte convocação:

Lançamos, pois, em nome da 'Sociedade Brasileira de Nutrição', esta idéia valiosissima, na certeza de que as autoridades municipais a aproveitarão convenientemente, por intermédio dos setores de Saúde, Educação, e Propaganda. Questão fundamental do povo brasileiro, neste curso as preleções serão resumidas e irradiadas para todo Brasil, levando por toda parte os ensinamentos ministrados no recinto iluminado e festivo da Feira de Amostras. (Carmo, 1937:15)

Além disso, Carmo assinalava que escrevera no Jornal do Brasil, numa seção destinada às suas colaborações, sob o título 'Problemas de alimentação', o artigo sobre 'O papel da Escola'. Seus primeiros artigos sobre alimentação visavam passar em revista os elementos doutrinários que se achavam ligados aos estudos da nutrição, abordando depois as questões práticas. Desse modo, ele explicava que já havia tratado da população, produção, inquéritos, focalizando, naquele momento, o papel importantíssimo e insubstituível da escola que, ao lado da imprensa, formava as duas potentes alavancas com que se podia contar numa campanha pedagógica de alimentação.

No setor da educação, a escola primária era a instituição mais requisitada para materializar esse plano educacional, pois a escola não era somente o instrumento de educação, era também de saúde. Ela se apresentava como a encruzilhada na qual passava a maioria e na qual se podia chegar a tempo de salvar uma geração que se degradava pelos vários fatores disgênicos. Nesse aspecto, Carmo (1937) avançava em relação a Coutinho (1937) e Costa (1938), delineando as linhas gerais de um plano de higiene alimentar e educação alimentar para o escolar, pois na escola era fácil fazer o diagnóstico precoce da subalimentação e, com o trabalho em cooperação, já em andamento naqueles anos, tal tarefa era perfeitamente acessível ao mestre, à enfermeira escolar, à visitadora, a grande número de pais (membros dos círculos), cabendo ao clínico escolar ser o árbitro desses diagnósticos, nos exames periódicos dos seus escolares.

Quanto a isso, eram os escolares ótimos difusores das fórmulas e, mais do que isso, os seus melhores fiscalizadores. Aproximava-se Carmo (1937) do 
modelo americano quando assinalava que no regime escolar daquele país existiam vários tipos de questionários feitos por intermédio dos alunos, pondo a família em estreita cooperação com a escola. Eram os school records para as informações diárias, semanais e mensais. O aluno levava para casa, os pais enchiam $e$ enviavam para a administração das escolas, onde era feito o controle.

Na escola brasileira, tal campanha era detalhadamente dividida por Carmo (1937) em dois níveis de ação, aqui resumidos:

- inquérito feito nos moldes já descritos e com a cooperação de outras entidades, serviço este de caráter externo;

- campanha racional da alimentação dentro da escola, compreendendo:

- ensino da alimentação nos cursos primário, secundário e superior;

- assistência aos subalimentados, feita pelo fornecimento de uma ração diária na escola, sob a forma de merenda, sopa escolar, mingaus ou copo de leite, utilizando-se para isso dos meios acessíveis do local (banana, laranja, fubá de milho, canjica etc.) (Carmo, 1937).

Nessa cruzada educacional, Carmo (1937) exemplificava o esforço desenvolvido pela iniciativa particular, como a National Education Association, Association for Prevention and Relief of Heart Disease, American Child Health Organization etc. No caso do Brasil, ele não desconhecia o valor de várias associações e de instituições científicas e de benemerência, que podiam ser mobilizadas para a referida campanha: a Associação Brasileira de Educação, a Sociedade dos Amigos de Alberto Torres, a Associação Brasileira de Imprensa, a Associação Brasileira de Farmacêuticos, o Rotary Club do Brasil, o Instituto de Proteção à Infância (Moncorvo Filho), a Associação dos Suboficiais da Armada e tantas outras, cuja atividade em serviços sociais era conhecida.

Em nível global, os pontos mais visados nessas campanhas deviam ser o da propaganda do uso abundante do leite e da abstenção do álcool, do maior consumo de frutas e verduras (laranja, lima, banana, limão, manga, abacaxi, abacate, tangerinas mamão, coco, tomate etc.), chamando a atenção para a composição, poder alimentício e riqueza em vitaminas (Carmo, 1937).

No plano geral, tudo seria feito pela iniciativa da Sociedade Brasileira de Nutrição, que em cada localidade se articularia com as autoridades e a sociedade, a fim de promover a campanha da boa alimentação. Seriam feitas palestras nos meios coletivos: fábricas, associações, sindicatos, clubes esportivos ou recreativos. Os jornais publicariam essas conferências, ou resumos atraentes, com cardápio organizado de acordo com a estação e com a época dos alimentos mais abundantes. Essa entidade destacaria seus membros para fazer tais palestras, sendo de vantagem instituir um modelo de conferência padrão, para evitar longas tiradas, incompreensíveis e fatigantes para o auditório (Carmo, 1937). 
Quanto a isso, segundo Carmo (1937), foi para o carreamento e coordenação dessas idéias que ele havia ajudado a fundar a Sociedade Brasileira de Nutrição, em agosto de 1936, idealizando a sua estrutura e as suas atribuições:

- convocação de um congresso nacional de alimentação;

- criação do Instituto da Nutrição;

- organização de um Código Alimentar Brasileiro;

- promoção de pesquisas relativas aos alimentos e à nutrição;

- procedimento de um inquérito amplo no território nacional, a fim de apurar como era feita a alimentação no seio de todas as classes sociais;

- criação do Comitê Nacional de Alimentação;

- instituição de uma campanha pedagógica de caráter nacional, compreendendo o ensino da alimentação nas escolas públicas, secundárias e superiores e a intensificação de uma propaganda de alimentação sistematizada, utilizando todos os meios coletivos e principalmente o lar; e

- fundação de uma revista de nutrição, órgão de estudo e de propaganda.

Para Carmo (1937), as idéias sobre um congresso nacional de alimentação não eram novas, visto que, em 1924, quando se reuniu o Congresso de Óleos, sob a orientação da Sociedade Brasileira de Química, o professor Freitas Machado havia apresentado proposta nesse sentido. Outro fato a destacar era a campanha pertinaz sustentada de longa data pelos técnicos do Laboratório Bromatológico, em favor da padronização dos métodos de análise química segundo um código obrigatório.

Com isso, Carmo (1937) mencionava vários eventos científicos no campo da química que dão, em certa medida, uma noção do peso que representou esse campo no movimento de gênese e constituição do campo da nutrição/ educação alimentar. Na definição de um Código Alimentar estiveram envolvidos - 1 Congresso Nacional de Química (1919), o 1 Congresso Brasileiro de Eugenia (1929) e o 3으 Congresso Sul-Americano de Química (s/d), quando finalmente o químico dr. Alves Filho teve a sua proposta de uniformização de métodos de análise bromatológica aprovada unanimemente, a qual fazia parte da coleção da Biblioteca de Nutrição. Por sua vez, Carmo havia apresentado ao 3o Congresso Brasileiro de Química (1937) uma moção convocando o Primeiro Congresso Nacional de Alimentação, que também foi aprovada. Eram iniciativas que marcavam os primeiros esforços de criação de eventos $e$ instituições mobilizadoras do processo de constituição da ciência da nutrição.

Quanto à criação do Instituto de Nutrição, Carmo (1937) assinalava que a alimentação científica não podia deixar de se inspirar na fisiologia alimentar, na bioquímica, na bromatologia, na toxicologia, na higiene etc. Esse problema 
ia sendo enfrentado por todas as nações sul-americanas. Na Argentina, por exemplo, graças à audácia de homens verdadeiramente empreendedores, como o professor Pedro Escudero, Araoz Alfaro e Emilio Schelh, um Instituto de Nutrição, modelar, erguia-se honrando a cultura platina e contribuindo com pesquisas e observações preciosas. Isso também já era uma questão resolvida em vários países, como no Japão (Instituto Imperial de Nutrição, fundado por Tadasa Saiki), na Holanda, na Espanha, nos Estados Unidos.

O Instituto Nacional de Nutrição teria como finalidade pôr termo ao empirismo reinante, em matéria de alimentação até aquele momento. Assim, em 1935, o deputado Teixeira Leite (de Pernambuco) já havia apresentado na Câmara dos Deputados um projeto de criação do referido Instituto, que seria, além de centro de investigações, um órgão de orientação e propaganda. A esse respeito, Carmo (1937) se reportava a uma entrevista dada ao Diário Carioca sobre o assunto, na qual reiterava que, numa expressão abrangente da questão alimentar, a célula-mãe estava representada pelo Instituto de Nutrição, visto como nele ficariam vinculados, na perspectiva do determinismo prático, os estudos e pesquisas de toda ordem que o caso comportava, para, por meio dos seus meios comparativos, das suas fichas biológicas minuciosas, tirar conclusões e deduções, com o fim de aplicá-las no meio local. Quanto a isso, para ele, seria fácil compreender o valor do Instituto de Nutrição, relembrando o que significou para a ciência brasileira a criação do Instituto de Manguinhos.

Nessa perspectiva, ele descrevia duas propostas de organização do Instituto Nacional de Nutrição em andamento: a de 1935, elaborada por uma comissão de técnicos, composta dos drs. Alexandre Moscoso, Ulhôa Cintra, Couto e Silva e Oswaldo Costa, inspirada no modelo argentino, e outra de 1929, elaborada pelo dr. Paulo Rodrigues, inspirada em outros congêneres, e nos trabalhos realizados na Alemanha, onde o Reich já possuía seu Ministério da Alimentação (ver Anexos 2 e 3).

Uma síntese desse plano de Carmo (1937) mostra que o conhecimento produzido sobre alimentação, a partir de 1937 , configurava o caminho da racionalidade nacional e, com ele, as estruturas institucionais necessárias à sua legitimação. Em consonância com a definição das bases científicas da ração alimentar racional média, ia-se conformando o campo da higiene alimentar na perspectiva da determinação dos padrões dietéticos regionais a serem viabilizados pelo Estado por uma política alimentar que, ao tempo que deveria prestar assistência alimentar, deveria promover as reformas necessárias no sistema econômico produtivo. Tais reformas consistiam em reorientar a posse e uso da terra, a política agrícola, o setor da pesca, a política de preços dos gêneros 
alimentícios, a política salarial, a escola etc., instaurar a educação alimentar em todas essas instâncias na qual se fizessem presentes o escolar, o trabalhador urbano, o trabalhador rural e o trabalhador do mar, assim como criar o Instituto de Nutrição como a célula-mãe representativa de todos os estudos e pesquisas nos vários ângulos que a situação alimentar comportava. Assim, essa instituição estaria comprometida no seu nascedouro não somente com a produção do conhecimento, mas também com a formulação e viabilização da política alimentar nacional.

Reforçando essa visão de Carmo, Moscoso (1939) indicava as linhas gerais da política alimentar do trabalhador, constituindo a educação alimentar como instrumento mais prático e o mais eficaz para o início da luta contra esta calamidade - a má alimentação. Era indispensável educar o povo em matéria de alimentação, era imprescindível ensinar o trabalhador a comer:

É imperioso um programa de educação alimentar, elaborado para classes e cursos de nutrição nas escolas primárias, secundárias e superiores, nas associações, nos diferentes estabelecimentos de trabalho, nas associações, nos sindicatos, nas instituições católicas, além da criação de escolas especializadas de nutrição e economia doméstica para mães, enfermeiras, professoras e nutricionistas. As escolas rurais, os patronatos, as colônias agrícolas devem ser centros de encaminhamento de nutrição que despertam, também, o interesse pela plantação e criação e que possam, como fontes produtoras, suprir as outras coletividades oficiais. (Moscoso, 1939:95-96)20

Nessa proposição, a educação alimentar se instrumentalizava também pelos meios modernos de divulgação, conselhos pela imprensa, rádio, cinema, em folhetos, nas escolas, colégios oficiais, fábricas, sindicatos e associações, distribuição de cartazes sugestivos nos estabelecimentos públicos e particulares, meios de transporte, vias públicas, feiras, exposições. No entanto, complementar à educação, segundo Moscoso (1939), eram as medidas fiscalizadoras das rações que deviam ser acionadas pelos regulamentos de saúde pública e do trabalho nos colégios, orfanatos, patronatos, casas comerciais, fábricas e coletividades particulares e a implantação de rações adequadas aos diversos grupos, de acordo com o trabalho, sexo e as idades. A fiscalização das rações deveria ser feita por técnicos especializados.

${ }^{20}$ Quanto a isso, embora a criação de um Instituto de Nutrição ainda fosse um projeto, o período de 1934 a 1939 já indicava novos horizontes, com a criação do primeiro curso de nutricionistas no então Instituto de Higiene da Faculdade de Saúde Pública da Universidade de São Paulo/ USP, sob a iniciativa de Geraldo Horácio de Paula Souza. No entanto, a educação alimentar ainda não era uma realidade no currículo do referido curso, que foi constituído de um curso preliminar, em que figurava a disciplina anatomia e fisiologia humana e química biológica, e de um curso especializado em que figurava o estudo: dos alimentos; da digestão; do metabolismo intermediário; das principais doenças do metabolismo e os regimes alimentares (AssociaÇÃo BRASILEIRA DE NUTRIÇĀo, 1991). Como se pode notar, ainda era incipiente a configuração disciplinar nesse curso, que tinha duração de um ano. 
As instituições oficiais deveriam organizar cozinhas e refeitórios para o fornecimento de alimentação adequada e barata aos funcionários, fiscalizada a composição por técnicos competentes. Os órgãos de previdência social organizariam também cozinhas distribuidoras de rações, que seriam transportadas em caminhões aos centros de concentração operária, para distribuição rápida, fácil e barata. Os estabelecimentos industriais teriam locais apropriados, com os requisitos higiênicos indispensáveis, no qual os trabalhadores poderiam utilizarse dessas rações adequadas, sem perda de tempo, sem fadiga e com proveito para a sua saúde. (Moscoso, 1939).

Quanto a isso, Moscoso (1939) destacava as experiências da Venezuela, Peru, França, Itália, Estados Unidos, Argentina e Uruguai, entre outros, na instalação de refeitórios públicos e baratos para o trabalhador. O êxito alcançado estimulou sua difusão, e estendeu-se o plano também para o operário. Tais refeitórios tinham alta finalidade educativa; o trabalhador passaria a compreender o que lhes faria bem, aprenderia a alimentar-se e transportaria para o lar a noção de uma boa alimentação, adquirida pelo hábito, sentindo-se mais forte e com melhor disposição para o labor diário contínuo. O empregador teria maior lucro pelo trabalho mais produtivo, mais eficiente e mais perfeito. O Estado obteria resultado porque os hospitais ficariam menos lotados com a diminuição das doenças carenciais, da anemia, da tuberculose etc. O País aproveitaria porque teria filhos mais fortes e mais sadios. Por serem reconhecidamente úteis esses refeitórios para o trabalhador, é que necessitavam de estudo detalhado, de plano perfeito e exeqüivel, de modo a facilitar a boa alimentação. Nesse aspecto, Moscoso (1939) indicava as linhas centrais da organização e funcionamento dos restaurantes públicos, que não cabe neste trabalho analisar. Porém, é possível concluir que essas eram as linhas mestras da política alimentar que motivou a criação do Serviço de Alimentação da Previdência Social (SAPS), em 1940.

Vale destacar finalmente que, para além das proposições anteriormente descritas, a política alimentar assim concebida deveria viabilizar também a aquisição dos alimentos por um conjunto de medidas de barateamento dos preços: multiplicidade de transportes, redução de fretes e impostos, disseminação de meios e locais de distribuição, oferecimento vantajoso ao consumidor, com lucro mais direto ao produtor, privilegiando os gêneros nacionais e os produtos regionais. Nesse aspecto, os intelectuais foram, de fato, os idealizadores da política alimentar na perspectiva da reconstrução nacional, no período de 1934 a 1939 , como afirmava Moscoso:

Urge seja traçada uma diretriz decisiva de iniciativa individual e patriótica para a solução do problema em favor da boa, adequada e suficiente alimentação do 
trabalhador. Tudo que for feito nesse sentido será em benefício do povo e pelo engrandecimento da Pátria. (Moscoso, 1939:100)

Um balanço sintético do período de 1934 a 1939 permite visualizar como característica fundamental do conjunto da produção em foco o lançamento das bases científicas da alimentação, pela aproximação da fisiologia comparada com o método geográfico, na perspectiva da demonstração da tese 'mal de fome e não de raça'. O método geográfico foi usado por Castro (1937), Carmo (1937), Coutinho (1937), Mendonça (1938) e Botelho (1938), não sendo usado por Costa (1938) e Moscoso (1939), indicando que houve uma tendência majoritária empenhada na aplicação do método geográfico na perspectiva da conexão entre o biológico e o social, embora os que se afastaram desse método também estivessem na mira do mesmo objeto.

Não obstante a tendência majoritária ter-se orientado em maior ou menor grau em torno de um eixo comum - as características da organização social -, ela se diversificou na eleição das categorias de estudo da fome e da subalimentação, priorizando, diferentemente, mas de modo complementar, quer por estudos teóricos, quer por investigações empíricas (como as de Castro, de Carmo e de Coutinho), aspectos como: economia, monocultura, salário, pobreza, hábitos alimentares, ignorância. É importante destacar que em ambas as tendências a ignorância se estabeleceu como categoria justificadora fundamental na constituição da educação alimentar, embora Coutinho tenha enfatizado mais o fator econômico, o que, entretanto, não impediu que também ele recomendasse a inclusão da educação alimentar na escola. Além disso, outro elemento compartilhado pelo grupo foi o princípio pelo qual o conhecimento produzido valia não apenas pela perspectiva de aplicação de um método único que individualizasse o campo da ciência da nutrição/educação alimentar, mas também pelos resultados que de imediato pudesse apresentar, fato que remetia à sua dimensão finalista: a delimitação, em maior ou menor grau, das linhas básicas de uma política alimentar para o Brasil na qual a educação alimentar era o instrumento mais eficaz. 